PNNL-13037, REV. 1

\title{
Geochemical Data Package for the Hanford Immobilized Low-Activity Tank Waste Performance Assessment (ILAW PA)
}

D. I. Kaplan ${ }^{(a)}$

R. J. Serne

February 2000

Prepared for

the U.S. Department of Energy

under Contract DE-AC06-76RLO 1830

Pacific Northwest National Laboratory

Richland, Washington 99352

(a) Westinghouse Savannah River Company

Aiken, South Carolina 29808 



\section{DISCLAIMER}

This report was prepared as an account of work sponsored by an agency of the United States Government. Neither the United States Government nor any agency thereof, nor any of their employees, make any warranty, express or implied, or assumes any legal liability or responsibility for the accuracy, completeness, or usefulness of any information, apparatus, product, or process disclosed, or represents that its use would not infringe privately owned rights. Reference herein to any specific commercial product, process, or service by trade name, trademark, manufacturer, or otherwise does not necessarily constitute or imply its endorsement, recommendation, or favoring by the United States Government or any agency thereof. The views and opinions of authors expressed herein do not necessarily state or reflect those of the United States Government or any agency thereof. 


\section{DISCLAIMER}

Portions of this document may be illegible in electronic image products. Images are produced from the best available original document. 


\begin{abstract}
Lockheed Martin Hanford Company (LMHC) is designing and assessing the performance of disposal facilities to receive radioactive wastes that are stored in single- and double-shell tanks at the Hanford Site. The preferred method of disposing of the portion that is classified as low-activity waste is to vitrify the liquid/slurry and place the solid product in near-surface, shallow-land burial facilities. The LMHC project to assess the performance of these disposal facilities is the Hanford Immobilized Low-Activity Tank Waste (ILAW) Performance Assessment (PA) activity. The goal of this project is to provide a reasonable expectation that the disposal of the waste is protective of the general public, groundwater resources, air resources, surface-water resources, and inadvertent intruders. Achieving this goal will require prediction of contaminant migration from the facilities. This migration is expected to occur primarily via the movement of water through the facilities, and the consequent transport of dissolved contaminants in the porewater of the vadose zone.
\end{abstract}

Pacific Northwest National Laboratory (PNNL) ${ }^{(a)}$ assists LMHC in their performance assessment activities. One of the PNNL tasks is to provide estimates of the geochemical properties of the materials comprising the disposal facility, the disturbed region around the facility, and the physically undisturbed sediments below the facility (including the vadose zone sediments and the aquifer sediments in the upper unconfined aquifer). The geochemical properties are expressed as parameters that quantify the adsorption of contaminants and the solubility constraints that might apply for those contaminants that may exceed solubility constraints. The common parameters used to quantify adsorption and solubility are the distribution coefficient $\left(\mathrm{K}_{\mathrm{d}}\right)$ and the thermodynamic solubility product $\left(\mathrm{K}_{\mathrm{sp}}\right)$, respectively. In this data package, we approximate the solubility of contaminants using a more simplified construct, called the solution concentration limit, a constant value. In future geochemical data packages, we will determine whether a more rigorous measure of solubility is necessary or warranted based on the dose predictions emanating from the IIAW 2001 PA and reviewers' comments.

The $\mathrm{K}_{\mathrm{d}} \mathrm{S}$ and solution concentration limits for each contaminant are direct inputs to subsurface flow and transport codes used to predict the performance of the ILAW system. In addition to the best-estimate $\mathrm{K}_{d} \mathrm{~S}$, a reasonable conservative value and a range are provided. We assume that $\mathrm{K}_{d}$ values are log normally distributed over the cited ranges. Currently, we do not give estimates for the range in solubility limits or their uncertainty. However, we supply different values for both the $K_{d} s$ and solution concentration limits for different spatial zones in the ILAW system and supply time-varying $\mathrm{K}_{d} \mathrm{~s}$ for the concrete zone, should the final repository design include concrete vaults or cement amendments to buffer the system $\mathrm{pH}$.

If warranted, more technically rigorous information on uncertainty in the geochemical parameter values and estimates of the changes in parameter values over time will be supplied in future data packages.

(a) PNNL is operated by Battelle for the U.S. Department of Energy. 


\section{Acknowledgments}

We wish to thank the following Hanford Site and external reviewers for their insightful reviews of this data package. The reviewers considered geochemical technical comments, systems performance assessment comments and readability comments, for both lay persons and waste management/regulators who must make policy decisions based on the long-term predictions that emanate from performance assessment activities.

- Fred Mann, Fluor Daniel Northwest, Inc.

- Harry Babad, Westinghouse Hanford Company retired (private consultant)

- Tom E. Jones, MACTEC-Meier

- Carol Babel, U.S. Department of Energy, Richland Operations Office

- Patrick V. Brady, Sandia National Laboratories

- Steve Serkiz, Westinghouse Savannah River Company

- Tjalle T. (Chuck) Vandergraaf, Atomic Energy of Canada, Limited at Pinawa, Manitoba, Canada. 


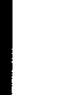




\section{Table of Contents}

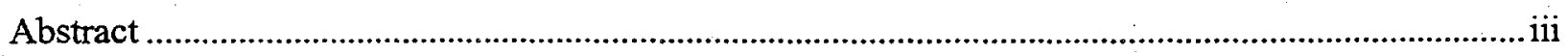

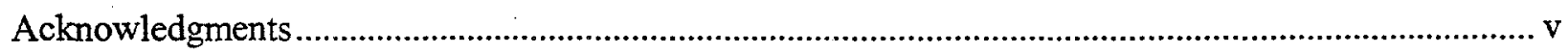

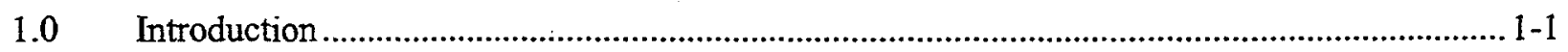

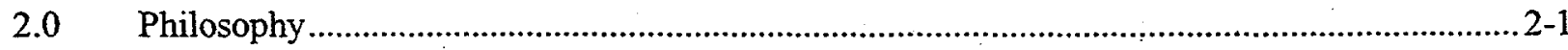

2.1 Relation Between Distribution Coefficients and Retardation Factors ......................... 2-1

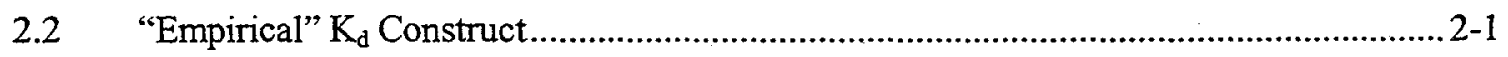

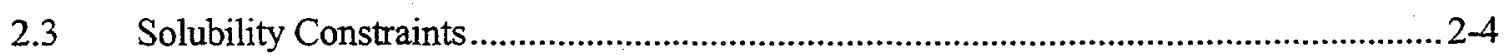

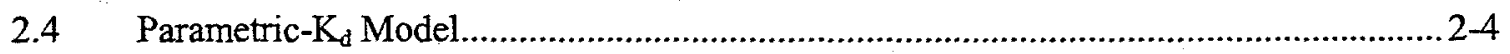

2.5 Overview of Mechanistic Adsorption Models ....................................................... 2-6

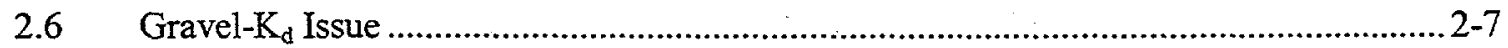

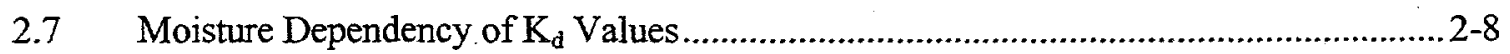

2.8 Colloid-Facilitated Transport of Contaminants...................................................... 2-9

3.0 Geochemistry of Key Radionuclides...........................................................................

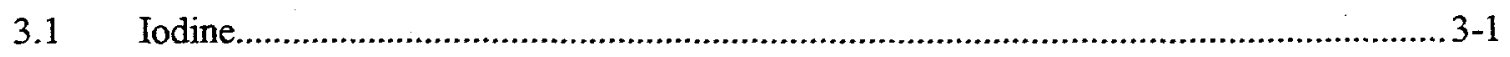

3.1.1 Aqueous Speciation................................................................................ $3-1$

3.1.2 Precipitation and Coprecipitation.......................................................... 3-1

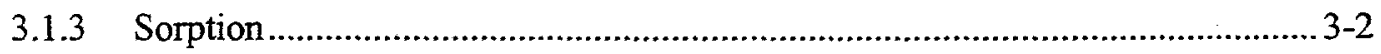

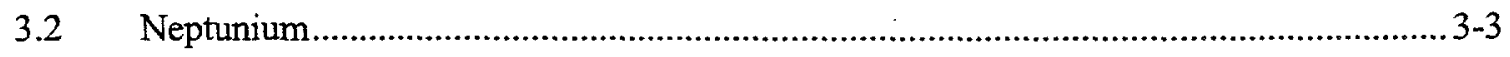

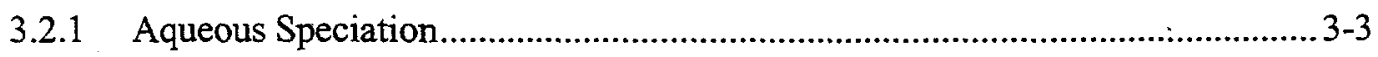

3.2.2 Precipitation and Coprecipitation.............................................................

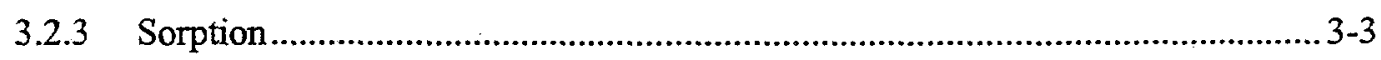

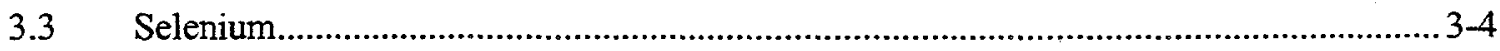

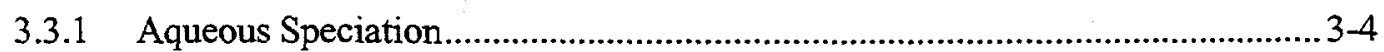


3.3.2 Precipitation and Coprecipitation............................................................ 3-4

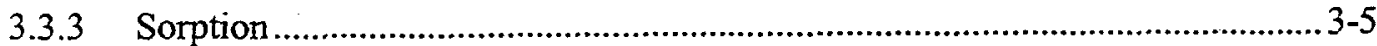

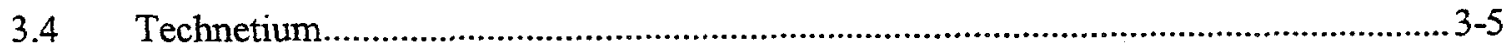

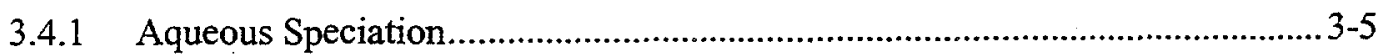

3.4.2 Precipitation and Coprecipitation........................................................... $3-6$

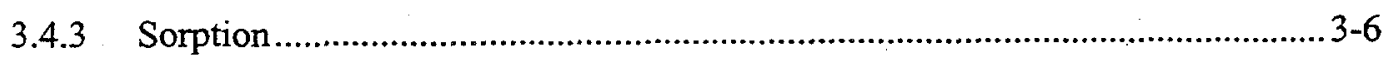

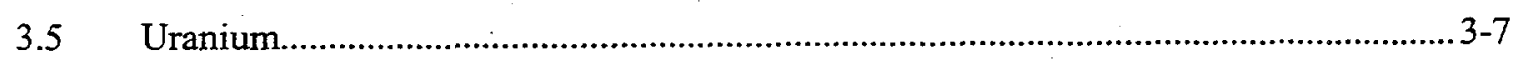

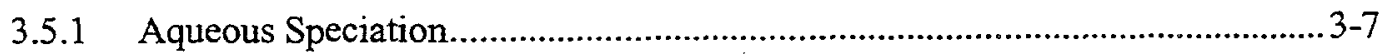

3.5.2 Precipitation and Coprecipitation............................................................... 3-8

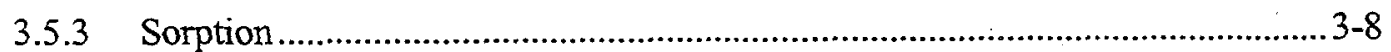

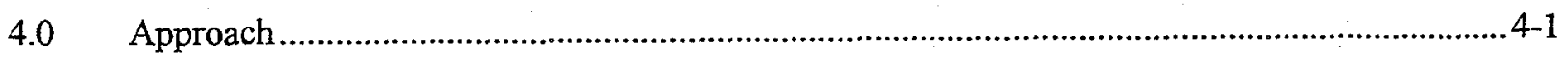

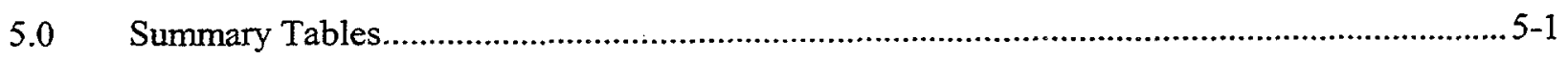

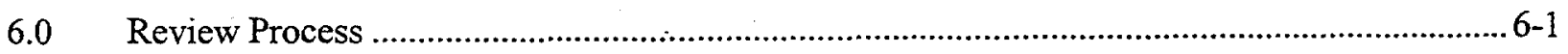

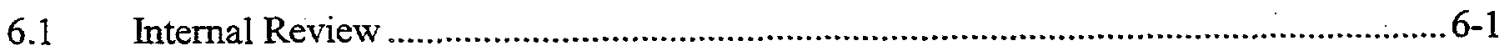

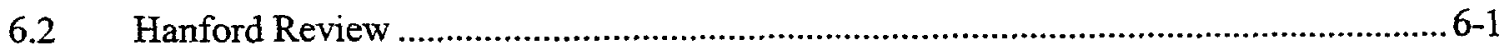

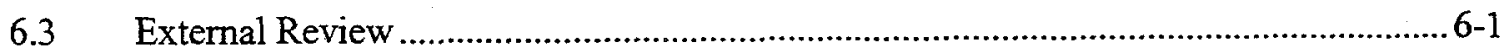

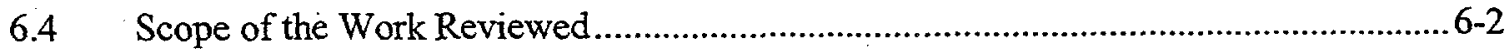

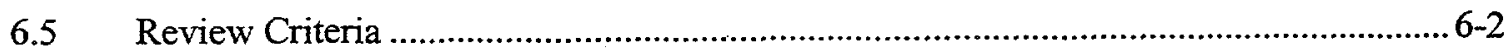

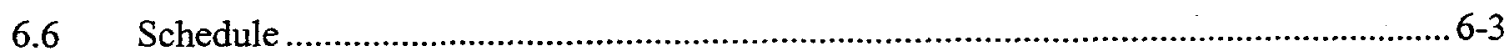

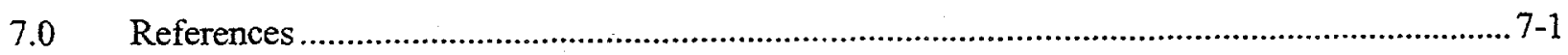

Appendix A - A Less Conservative Approach to Correcting $\mathrm{K}_{d}$ Values for the Presence of Gravel ...... A-1

Appendix $\mathrm{B}-\mathrm{K}_{\mathrm{d}}$ Values for Far-Field Sediment Conditions ....................................................... B-1

Appendix C - Discussion on Double Layer and Film Thickness ................................................. C-1

Appendix D - Information Requested for Near-Field Geochemical Transport Modeling.................... D-1 


\section{Figures}

1 Eh and pH Diagram for Iodine/Water System

2 Schematic Representation of the Five Geochemical Zones

\section{Tables}

1 Conceptual Features of the Five Geochemical Zones

2a $\quad \mathrm{K}_{\mathrm{d}}$ Values for Zone 1 - Near Field.

2b Solubility Values for Designated Solids in Zone 1 - Near Field

3a $\quad K_{d}$ Values for Zone 2-Degraded Concrete.

3b Solubility Limits for Designated Solids for Zone 2 - Degraded Concrete

$4 \quad \mathrm{~K}_{\mathrm{d}}$ Values for Zone 3 - Chemically Impacted Far Field in Sand Sequence.

5 Gravel-Corrected $\mathrm{K}_{\mathrm{d}}$ Values for Zone 4 - Chemically Impacted Far Field in Gravel Sequence

6 Gravel-Corrected $\mathrm{K}_{\mathrm{d}}$ Values for Zone 5 - Far Field in Gravel Sequence $5-18$

7 Schedule for Geochemical Data Package Approval. 


\subsection{Introduction}

The Hanford Immobilized Low-Activity Tank Waste Performance Assessment (ILAW PA) examines the long-term environmental and human health effects associated with the planned disposal of the vitrified low-activity fraction of waste currently contained in Hanford Site tanks. Greater than $200,000 \mathrm{~m}^{3}$ of tank waste have been created as the result of separating nuclear materials from irradiated nuclear fuels. This waste has been stored in 18 underground tank farms. The tank waste is to be retrieved, separated into low-activity and high-level fractions, and then immobilized by private vendors. The high-level fraction, which will be of low volume but contain most of the radionuclides, will be stored at Hanford until a national repository is approved. The low-activity fraction will be disposed of as vitrified waste in the 200 East Area.

The design of the ILAW disposal facilities is evolving. Although there are four existing concrete vaults with a total useable volume of $\sim 15,000 \mathrm{~m}^{3}$ that could be used, design staff are contemplating trench disposal in the 200 East Area.

The first ILAW PA of the 200 East Area was completed in 1998 and showed that groundwater transport presents the greatest potential for long-term dose uptake by humans (Mann et al. 1998). Of the numerous radionuclides evaluated in this $\mathrm{PA}$ (including $\mathrm{Ac}, \mathrm{Am}, \mathrm{C}, \mathrm{Ce}, \mathrm{Cm}, \mathrm{Co}, \mathrm{Cs}, \mathrm{Eu}, \mathrm{I}, \mathrm{Nb}, \mathrm{Ni}, \mathrm{Np}, \mathrm{Pa}, \mathrm{Pb}, \mathrm{Pu}$, $\mathrm{Ra}, \mathrm{Ru}, \mathrm{Se}, \mathrm{Sn}, \mathrm{Sr}, \mathrm{Tc}, \mathrm{Th}, \mathrm{U}$, and $\mathrm{Zr}$ ), the following isotopes were identified as posing the greatest potential health hazard: ${ }^{129} \mathrm{I},{ }^{237} \mathrm{~Np},{ }^{79} \mathrm{Se},{ }^{99} \mathrm{Tc}$, and ${ }^{234 / 235 / 238} \mathrm{U}$. Kaplan et al. (1995) described the geochemical factors affecting the transport of these radionuclides in the Hanford Site subsurface environment. It was also determined that the outcome of these simulations was very sensitive to the parameter describing the extent to which radionuclides sorbed to the subsurface sediment, the distribution coefficient, $\mathrm{K}_{\mathrm{d}}$. The distribution coefficient is the ratio of the radionuclide concentration associated with the solid phase to that in the liquid phase (described in more detail below). Near the buried vitrified waste, solubility constraints may also control the solution concentrations of contaminants. Thus, this data package contains empirically chosen "solubility limits" for selected contaminants in the regions close to the vitrified waste.

The purpose of this data package is to document the basis for selecting geochemical parameters and input values that will be used in the 2001 version of the ILAW PA. This data package consists of the philosophy, the key radionuclides, the approach, and the resulting tables of information. Also, a short chapter on the review process is included for completeness. 


\subsection{Philosophy}

\subsection{Relation Between Distribution Coefficients and Retardation Factors}

The distribution coefficient, or $\mathrm{K}_{\mathrm{d}}$ value, is the simplest construct describing contaminant sorption to sediments. It is the ratio of the contaminant concentration sorbed to the solid phase divided by the contaminant concentration in the liquid surrounding the solid phase (Equation 1):

$$
K_{d}=\frac{C_{\text {solid }}}{C_{\text {liquid }}}
$$

where $C_{\text {solid }}\left(\mathrm{M} \mathrm{kg}^{-1}\right)$ and $C_{\text {liquid }}\left(\mathrm{M} \mathrm{L}^{-1}\right)$ are the concentration in the solid and liquid phases, respectively. It is important to note that sorption, as expressed by $\mathrm{K}_{\mathrm{d}}$ values, is normalized by weight. Contaminant transport modelers commonly use $\mathrm{K}_{d}$ values to account for chemical interactions between the contaminant and the sediment. The $\mathrm{K}_{\mathrm{d}}$ value is used to define the retardation factor, which is the ratio of the average linear velocity of water $\left(\mathrm{m} \mathrm{s}^{-1}\right)$ divided by the average linear velocity of the contaminant $\left(\mathrm{m} \mathrm{s}^{-1}\right)$. For water saturated systems, the $\mathrm{K}_{\mathrm{d}}$ value is related to the retardation factor (Rf, unitless) by the bulk density $\left(\rho_{\mathrm{b}}, \mathrm{kg} \mathrm{m}^{-1}\right)$ and the porosity $\left(\eta, \mathrm{m}^{3} \mathrm{~m}^{-3}\right)$ as follows (Valocchi 1985, Bouwer 1991):

$$
R f=\left(1+\frac{K_{d} \rho_{b}}{\eta}\right)
$$

The bulk density and porosity terms in Equation 2 convert the weight-normalized $\mathrm{K}_{d}$ value into a volumenormalized value. Note that for partially saturated sediments, the porosity term is replaced by the volumetric water content of the vadose zone sediments.

\section{2 "Empirical" $K_{d}$ Construct}

The geochemical behavior of radionuclides in the subsurface will be described for the ILAW PA using two parameters, the distribution coefficient $\left(\mathrm{K}_{\mathrm{d}}\right.$ value $)$ and the solubility product $\left(\mathrm{K}_{\mathrm{sp}}\right)$ of a specified solid. The distribution coefficient is a thermodynamic construct. It is the ratio of the concentration of a species reversibly adsorbed/exchanged to a geomedium's surface sites divided by the concentration of the species in the surrounding solution. Using uranyl as an example, the definition of a specie-specific $\mathrm{K}_{d}$ as a thermodynamic construct is:

$$
K_{d-\text { thermo }}=\frac{X \equiv U O_{2}^{2+}}{U O_{2}^{2+}}
$$

where $\mathrm{X} \equiv \mathrm{UO}_{2}{ }^{2+}$ is the activity of the uranyl species reversibly adsorbed to a specific surface site $\mathrm{X}$, and $\mathrm{UO}_{2}{ }^{2+}$ is the activity of dissolved "free" uranyl species at equilibrium with the surface site $\mathrm{X}$. Among the many assumptions underpinning $\mathrm{K}_{d-t h e r m o}$ is that adsorption is fully reversible and the presence of adsorbed uranyl species does not influence subsequent adsorption of other dissolved uranyl or other 
contaminant species. Thus, a single distribution coefficient is used to represent both sorption and desorption of each contaminant species.

However, in order to apply the $\mathrm{K}_{\mathrm{d}}$ construct to contaminant transport and performance assessment calculations, the definition of the construct is relaxed. The definition needs to be relaxed for several reasons. In natural systems, a multitude of different types of sorption sites exists. Also, it is very difficult to measure the thermodynamic activity of individual chemical species on the adsorbents' surfaces. Furthermore, the measurement of thermodynamic activities of dissolved species is rarely performed and, as just mentioned for adsorbates on solids, no techniques exist for the measurement of their thermodynamic activity. The parameters that can be readily measured are the total contaminant concentration or radionuclide activity (not to be confused with thermodynamic activity) as opposed to the concentration/ radioactivity of each individual species. Thus, the $\mathrm{K}_{\mathrm{d}}$ construct, as defined in Equation 3, requires differentiating and quantifying each type of surface site and each solution species. Additionally, spatial variability of the surface sites and groundwater chemistry in natural systems can not practicably be characterized to the degree necessary for the full implementation of species' specific sorption models, such as the triple layer surface complexation model (see Kent et al. 1988 for a good overview and Jenne 1998 for a recent compilation of related articles).

The empirical definition of the $\mathrm{K}_{\mathrm{d}}$ value becomes the ratio of the concentration of the complete suite of species [the sum of the total concentration of all species that include the contaminant of interest] sorbed by an assemblage of surface sites, divided by the summed concentration of the suite of species (total concentration) in solution. Again, using uranyl as an example, the definition of the thermodynamic $\mathrm{K}_{\mathrm{d}}$ construct would be for a simple system that contained three $\mathrm{U}(\mathrm{VI})$ species $\left[\mathrm{UO}_{2}{ }^{2+}, \mathrm{UO}_{2}(\mathrm{OH})^{+}\right.$, and $\left.\mathrm{UO}_{2}(\mathrm{OH})_{2}{ }^{0}\right]$ :

$$
K_{d-\text { therm }}=\frac{\sum \text { Adsorbed U Species }}{\sum \text { Dissolved U Species }}=\frac{X \equiv U \mathrm{O}_{2}^{2+}+X \equiv U \mathrm{UO}_{2}(\mathrm{OH})^{+}+X \equiv U \mathrm{UO}_{2}(\mathrm{OH})_{2}^{0}}{U \mathrm{UO}_{2}^{2+}+U \mathrm{UO}_{2}(\mathrm{OH})^{+}+U \mathrm{UO}_{2}(\mathrm{OH})_{2}^{0}}
$$

where $X \equiv$ is an average sorbent site (more than one sorbent site-type is expected in nature). The numerator and denominator in Equation $4 a$ are summed over contaminant species sorbed as well as sorbent sites. The empirical $K_{d}$ equation would be:

$$
K_{d}=\frac{\text { Total } U(V I)}{\text { Total } U(V I)} \frac{\text { on Solid }}{\text { in Solution }}
$$

Among the reasons for selecting the "empirical" $\mathrm{K}_{d}$ construct for the 2001 ILAW PA, as exemplified by Equation $4 b$, is

1. the bulk of the existing sorption literature on radionuclide sorption, especially at the Hanford Site, can be classified as "empirical" $K_{d}$ values

2. under the expected low concentrations of the contaminants in the far field, sorption can be considered to be independent of contaminant concentration and, therefore, $K_{d}$ is a constant for a given contaminant/geological material combination under identical (geo)chemical conditions 
3. $\mathrm{K}_{\mathrm{d}}$ can be used directly in codes used for performance assessments, such as the code PORFLO used in past ILAW predictions and the code VAM3DF to be used in future far-field vadose zone transport calculations (see Khaleel 1999)

4. perhaps most important, there is no thermodynamically based conceptual model or numerical code that is robust enough to accurately. predict the degree of radionuclide adsorption by natural sediments (see below).

By using site-specific materials in ILAW-funded experiments, it is possible to gather relevant data directly and not to rely on extrapolation from other sediment and aqueous systems. The problem with the rigorous thermodynamic species approach is that there is no numerical or conceptual model developed that is sufficiently robust to predict accurately the degree of radionuclide adsorption by natural sediment (Sposito 1984, Westall 1994, 1986, Wang et al. 1997, Davis et al. 1998). However, mechanistic models provide the necessary paradigms on which

Mechanistic models, though impractical for PA purposes, provide the necessary paradigms upon which "empirical" $\mathrm{K}_{\mathrm{d}}$ values must be based. technically defensible "empirical" $K_{d}$ values must be based. For most of the data used in the ILAW PA geochemical data package, sorption experiments have been conducted with site-specific sediment and site-specific groundwater, which resembles natural vadose zone porewaters.

Another aspect of the $\mathrm{K}_{\mathrm{d}}$ construct that is typically relaxed when used in contaminant transport calculations is the chemical process that it describes. As pointed out earlier, Equation 3 implies an adsorption or exchange reaction that is reversible. The laboratory $\mathrm{K}_{\mathrm{d}}$ measured with complex natural sediments and perhaps complex natural groundwater solutes, often reflect not only adsorption and exchange reactions, but also absorption, specific or somewhat irreversible adsorption, surface complexation, and varying degrees of (co)precipitation reactions. Identifying the processes that govern radionuclide chemical behavior is the single most important task necessary for estimating $K_{d}$ values for the ILAW PA. Once the dominant geochemical process is identified for a specific geological and chemical environment, the range of "empirical" $K_{d}$ values can be narrowed. Radionuclide geochemical processes have been ascertained primarily through experiments in which a key parameter is systematically varied (e.g., suspension $\mathrm{pH}$ or ionic strength). The trends displayed during these experiments provide key information regarding radionuclide behavior

Identifying the processes that govern radionuclide chemical behavior is the single most important task necessary for estimating $\mathrm{K}_{\mathfrak{d}}$ values. Once the dominant geochemical process is identified for a specific set of environmental conditions, the range of reasonable values for the "empirical" $\mathrm{K}_{\mathrm{d}}$ parameter can be narrowed. and also shed light on which processes may be controlling the radionuclide interaction between the solid and liquid.

The importance of first identifying the dominant geochemical process affecting radionuclide concentrations in the mobile aqueous phase can be illustrated through an experiment conducted for this project (Kaplan et al. 1998a). In this experiment, as the $\mathrm{pH}$ of Hanford Site sediment-groundwater slurries was increased from $\mathrm{pH} 8$ to $10, \mathrm{U}(\mathrm{VD})-\mathrm{K}_{d}$ values gradually increased from 1.3 to $3.5 \mathrm{~mL} / \mathrm{g}$. Above $\mathrm{pH} 10.5$ the amount of U(VI) removed from the aqueous phase increased by $>500$ fold. The initial increase in $\mathrm{K}_{\mathrm{d}}$ between $\mathrm{pH} 8$ and 10 was attributed to increased cation-exchange capacity of the sediment. That is, the number of $\mathrm{pH}$-dependent adsorption sites in the natural sediment, which attract cations, increased as the 
$\mathrm{pH}$ increased. The latter more dramatic increase was attributed to (co)precipitation of U(VI) with carbonate phases. These conclusions were supported by independent solubility calculations. What we learn from this particular study is much more than simply the magnitude of the $\mathrm{K}_{\mathrm{d}}$ value that should be used as an input parameter to the IIAW PA; we gain a plausible explanation of the processes governing U(VI) removal from solution. As this example illustrates, changes in the dominating chemical processes may account for an appreciable amount of variability in derived $\mathrm{K}_{\mathrm{d}}$ values under different geochemical conditions.

\subsection{Solubility Constraints}

In addition to the $\mathrm{K}_{d}$ construct, solubility products, (both thermodynamically and empirically based), are being used to describe radionuclide geochemical behavior in the ILAW disposal site. The solubility constraints used for conditions where the calculated concentrations of the radionuclides are believed to exceed the solubility of an assumed controlling phase. The selection of controlling solid phases will be based on laboratory experiments and when experimental data are not available, on literature results. If the thermodynamic data for the solid phase is not available from laboratory experiments or the literature, then it will be calculated using chemical speciation and solubility algorithms. Once the solid phase is selected, the upper limit of radionuclide concentration will be calculated with the appropriate background electrolyte composition. If the background electrolyte composition remains essentially constant then the solubility product can be assumed to also be nearly constant. This has led some PA practitioners to refer to solubility constraints as constants but in reality

When the controlling solid could not be identified but empirical solubility tests clearly indicate that some phase is controlling solution concentration, then an empirical solubility relationship will be constructed. the solubility constant, $\mathrm{K}_{\mathrm{sp}}$, varies with solution chemistry. When radionuclide concentrations exceed the $\mathrm{K}_{\mathrm{sp}}$, precipitation can be expected and subsequent radionuclide aqueous concentrations and behavior is controlled by solubility. At concentrations below this limit, the radionuclide concentration will be controlled by the "empirical" $K_{d}$ construct. When the controlling solid can not be identified but empirical solubility tests clearly indicate that some unidentified phase is controlling solution concentration, then an empirical solubility relationship will be used. This empirical solubility product will include the key solution parameters as independent variables and the empirical solubility product as the dependent variable. In some cases the empirical $\mathrm{K}_{\mathrm{sp}}$ data may be simplified as a constant concentration limit. This is especially true for the 2001 ILAW PA because little site/waste form/engineered barrier solubility work has been performed that identifies the controlling solids. Recent thermodynamic tabulations by the Nuclear Energy Agency in France may prove to be valuable references. Three books are available with data on U, Am, and Tc (see Grenthe et al. 1992, Silva et al. 1995, and Amaia Sandino and Osthols 1999, respectively). Other solubility data for other radionuclides can be found at the NEA web page http://www.nea.fr/html/dbtdb.

\subsection{Parametric-K $\mathbf{K}_{\mathrm{d}}$ Model}

When using the constant- $\mathrm{K}_{\mathrm{d}}$ model, the retardation factor is a constant for each layer of geologic media (each layer is assumed to have a constant bulk density and water content or saturated effective porosity). The transport equation based on a constant- $\mathrm{K}_{\mathrm{d}}$ model does not require knowledge of any other geochemical parameters, such as $\mathrm{pH}$ or mineralogy, and it is easily solved to determine the solution concentration as a function of time and space. It is the use of the constant- $K_{d}$ model in retardation factor (Equation 2) 
that has caused most of the criticism; few natural groundwater pathways are spatially or geochemically homogeneous to the extent that the retardation factor for a species remains constant.

Clearly, the greatest limitation to the constant- $\mathrm{K}_{\mathrm{d}}$ approach is that it describes solute partitioning between the aqueous and solid phases for only one set of environmental conditions. Such homogeneity does not exist in nature and, therefore, greatly compromises the usefulness of the constant. For instance, when the aqueous phase chemistry was varied, Am- $\mathrm{K}_{d}$ values in a Hanford Site sediment ranged from 0.2 to $53 \mathrm{~mL} / \mathrm{g}$, roughly a 200-fold range (Delegard and Barney 1983). Additional variability in the Am- $\mathrm{K}_{\mathrm{d}}$ values, albeit less, was observed when slightly different Hanford Site sediments were used: 4.0 to $28.6 \mathrm{~mL} / \mathrm{g}$ (Delegard and Barney 1983, Solution 1). Using similar aqueous phases but sediments from around the country, Sheppard et al. (1976) measured $A m-K_{d}$ values ranging from 125 to $43,500 \mathrm{~mL} / \mathrm{g}$. (Interestingly, the lowest $\mathrm{K}_{\mathrm{d}}$ in this survey of 12 soils/sediments from U.S. Department of Energy (DOE) national laboratories was in a Hanford sediment.)

The $\mathrm{K}_{\mathrm{d}}$ value in the parametric model varies according to empirically derived relationships with aqueous and solid phase independent parameters. Thus, it has the distinct advantage of being more robust and removes the burden of determining new $K_{d}$ values for each environmental condition. Because the $K_{d}$ is a function of a large number of variables, it is common to vary systematically several parameters simultaneously in one experimental study. Factorial design strategies are most often invoked to determine the systematic change resulting from varying the independent variables on the dependent variables, typically the distribution coefficient (Cochran and Cox 1957, Davies 1954, Plackett and Burman 1946, Box and Behnken 1960). Statistical methods commonly used to derive quantitative predictor equations include standard linear or nonlinear regression (Snedecor and Cochran 1967), stepwise regression (Hollander and Wolfe 1973), and adaptive-learning networks (Mucciard et al. 1979, 1980). All these techniques have been used to develop empirical relationships describing $\mathrm{K}_{d}$ values in terms of other variables (Routson and Serne 1972, Serne et al. 1973, Routson et al. 1981, Delegard and Barney 1983).

The empirical predictor equations commonly take the form of a nonlinear multinomial expression. For example, after evaluating solutions consisting of several sodium salts, organic chelates, and acids, Delegard and Barney (1983) came up with the following expression for a americium's $\mathrm{K}_{\mathrm{d}}$ value on one particular Hanford Site sediment:

$$
\log \left[\mathrm{K}_{\mathrm{d}}(\mathrm{Am})\right]=2.0+0.1[\mathrm{NaOH}]-26.8[\mathrm{HEDTA}]+153.4[\mathrm{HEDTA}]^{2}
$$

The independent parameters and their ranges used to develop Equation 5 were selected to simulate the plume of high-level waste that emanates from a steel-lined concrete tank into a sediment in the Hanford Site's 200 Areas Plateau. Numerous salts were found to have no significant effect on americium $\mathrm{K}_{d}$ values and, therefore, were not included in the expression. Delegard and Barney (1983) also evaluated higher exponential and logarithmic terms and determined that these terms did not improve the predictive capabilities of the expression (i.e., the regression coefficients were not significant at $\mathrm{P}<0.05$ ).

Although the empirical relationships generated from these types of statistical analyses are more powerful than knowledge of individual $K_{d}$ values, they cannot be used to predict $K_{d}$ values for conditions beyond the range studied. For example, the parametric- $\mathrm{K}_{d}$ values generated by Delegard and Barney (1983) for the 200 Areas Plateau are likely inappropriate for the vitrified low-level waste plume because the chemistry of the aqueous phase will be appreciably different. 
These types of statistical relationships are devoid of causality and, therefore, provide no certain information on the mechanism by which the radionuclide partitioned to the solid phase, whether by adsorption, absorption, precipitation, or coprecipitation. That is, the statistical analyses may suggest a very strong relationship between one variable, for instance $\mathrm{pH}$, and the distribution coefficient, when the actual sorption process may be controlled by iron oxide adsorption. Because $\mathrm{pH}$ and iron oxide surface charge are covariant, a statistical relationship could be calculated, suggesting that sorption is solely caused by $\mathrm{pH}$.

The parametric- $\mathrm{K}_{\mathrm{d}}$ model can be used in the retardation factor term (Equation 2). When used in a transport equation, the transport code must also keep track of the value of the independent variables, such as $\mathrm{NaOH}$ and HEDTA, for the examples described above; Equation 5) at each point in space and time. Keeping track of other variables is necessary to continually update the concentration of these independent variables that change the $\mathrm{K}_{d}$ value. Thus, the code must track many more parameters, and some numerical solving techniques, such as closed-form analytical solutions, can no longer be used to perform the integration necessary to solve for the contaminant's concentration. Generally, computer codes that can accommodate the parametric- $K_{d}$ model use a chemical subroutine to update the $K_{d}$ value used to determine the $R_{F}$, when called by the main transport code. The added complexity in solving the transport equation with parametric- $\mathrm{K}_{\mathrm{d}}$ sorption models and its empirical nature may be the reasons this technique has been used sparingly for waste disposal safety assessment exercises.

\subsection{Overview of Mechanistic Adsorption Models}

Mechanistic models explicitly accommodate the dependency of $\mathrm{K}_{\mathrm{d}}$ values on contaminant concentration, competing ion concentrations, variable surface charge on the adsorbent, and solute species distribution. Incorporating mechanistic, or semimechanistic, concepts into models is attempted because the models become more robust and, perhaps more important, for the standpoint of the ILAW PA, scientifically defensible. There are several mechanistic models describing solute adsorption; some are accurate only under limited environmental conditions (Sposito 1984). For instance, the Stern model is a better model for describing adsorption of inner-sphere complexes, whereas the Gouy-Chapman model is a better model for describing outer-sphere or diffuse swarm adsorption (Sposito 1984, Westall 1986). The complexity of installing these models into existing transport codes that are favored for complete disposal system performance assessment and the diversity of Hanford Site waste leachate/sediment/contaminant combinations of interest would require a data collection effort more intense and costly than is likely to be available. A brief description of the state of the science is presented below. References to excellent review articles have been included in the discussion to provide the interested reader with additional information.

Several mechanistic models have been proposed; however, their application to complex natural sediments is not resolved (Westall and Hohl 1980, Sposito 1984, Westall 1986, Schindler and Sposito 1991). Any complete mechanistic description of chemical reactions at the mineral-electrolyte interface must include a description of the electrical double layer. While this fact has been recognized for years, a satisfactory. description of the double layer at the mineral-electrolyte interface still does not exist.

Part of the difficulty of characterizing this interface stems from the fact that natural mineral surfaces are very irregular. They consist of many different microcrystalline structures that exhibit quite different chemical properties when exposed to solutions. Thus, examination of the surface by virtually any experimental method yields only averaged characteristics of the surface and the interface. Parson (1982) 
discussed the surface chemistry of single crystals of pure metals and showed that the potential of zero charge of different crystal faces of the same pure metal can differ by over $400 \mathrm{mV}$. For an oxide surface, this difference was calculated by Westall (1986) to be energetically equivalent to a variation in the zeropoint-of-charge of more than $6 \mathrm{pH}$ units. This example indicated that an observable microscopic property of a polycrystalline surface might be the result of a combination of widely different microscopic properties and that characterizations of these surfaces will remain somewhat operational in nature.

Another fundamental problem encountered in characterizing reactions at the mineral-electrolyte interface is the coupling between electrostatic and chemical interactions, which make it difficult to distinguish their effects between each other. Westall and Hohl (1980) have shown that many models for reactions at the mineral-electrolyte interface are indeterminate in this regard.

Many of the studies from which our understanding of reactions at the mineral-electrolyte interface have developed were based on titration of colloidal suspensions of minerals. Resolving questions left open by such research requires that the mineral surfaces be better defined (by many different spectroscopic and experimental methods), and that mathematical methods be developed for interpreting the data.

Experimental data on interactions at the mineral-electrolyte interface can be represented mathematically through two different approaches: 1) empirical models and 2) mechanistic models. An empirical model can be defined as a mathematical description of the experimental data without any particular theoretical basis. For example, the $\mathrm{K}_{\mathrm{d}}$, Freundlich isotherm, Langmuir isotherm, Langmuir Two-Surface Isotherm, and Competitive Langmuir are considered empirical models by this definition (Sposito 1984). Mechanistic models refer to models based on thermodynamic concepts, such as reactions described by mass action laws and material balance equations. Four of the most commonly used mechanistic models include the Helmholtz, Gouy-Chapman, Stern, and Triple Layer models (Sposito 1984). The empirical models are often mathematically simpler than mechanistic models and are suitable for characterizing sets of experimental data with a few adjustable parameters, or for interpolating between data points. On the other hand, mechanistic models contribute to an understand of the chemistry at the interface and are often used for describing data from complex multicomponent systems for which the mathematical formulation (i.e., functional relations) for an empirical model might not be obvious. Mechanistic models can also be used for interpolation and characterization of data sets in terms of a few adjustable parameters. However, mechanistic models are often mathematically more complicated than empirical relationships. Adjustable parameters are required for both mechanistic and empirical models, but not for the $K_{d}$ model.

\subsection{Gravel-K $\mathbf{K}_{\mathrm{d}}$ Issue}

Essentially all $\mathrm{K}_{d}$ values in the literature and that have been measured at the Hanford Site were generated from sediments that do not contain any gravel, particles $>2-\mathrm{mm}$. However, there are regions in the subsurface of the ILAW site that are composed primarily of gravel-sized particles. At issue is that $\mathrm{K}_{d}$ values will likely be lower in sediments containing gravel because of the reduced surface area in the field as compared to the lab tested solids for the radionuclides to interact with. This is referred to as the gravel- $\mathrm{K}_{\mathrm{d}}$ issue. Experiments were conducted with Hanford sediments to evaluate a number of methods to address the gravel- $\mathrm{K}_{\mathrm{d}}$ issue (Kaplan et al. 1999 and Appendix A). Three
To account for the presence of gravel in the study area, $\mathrm{K}_{d}$ values will be lowered in a conservative method, whereby the gravel will be assumed to have no sorptive capacity for the radionuclides. 
gravel-corrected $\mathrm{K}_{\mathrm{d}}$ conceptual models, $\mathrm{K}_{\mathrm{dgc}}$, were evaluated in this study: a correction based on surface area $\left(\mathrm{K}_{\mathrm{dgc} \text {,sur }}\right)$, a correction based on the assumption that the gravel simply diluted the $\mathrm{K}_{\mathrm{d} 2 \mathrm{~mm}}$ and had no sorption capacity $\left(\mathrm{K}_{\mathrm{dgc}, g=0}\right)$, and a correction based on the assumption that the $\mathrm{K}_{\mathrm{d}}$ of the entire sediment $\left(\mathrm{K}_{\mathrm{dtot}}\right)$ was a composite of the $\mathrm{K}_{\mathrm{d}<2 \mathrm{~mm}}$ and the $\mathrm{K}_{\mathrm{d}>2 \mathrm{~mm}}$ values $\left(\mathrm{K}_{\mathrm{dgc}, \mathrm{g}=\mathrm{x}}\right)$. Based on data for the adsorption of trace concentrations of $\mathrm{Sr}$, on average, $\mathrm{K}_{\mathrm{d}<2 \mathrm{~mm}}$ tended to overestimate $\mathrm{K}_{\mathrm{dtot}}$ by $28 \% ; \mathrm{K}_{\mathrm{dgc}, 0=\mathrm{x}}$ overestimated

$\mathrm{K}_{\mathrm{dtot}}$ by only $5 \% ; \mathrm{K}_{\mathrm{dgc}, \mathrm{g}=0}$ and $\mathrm{K}_{\mathrm{dgc}, \text { surf }}$ underestimated $\mathrm{K}_{\mathrm{dtot}}$ by 10 and $13 \%$, respectively. Although, $\mathrm{K}_{\mathrm{dgc,g}=\mathrm{x}}$ provided the best estimate of actual values $\left(\mathrm{K}_{\mathrm{dtot}}\right)$, the input values for $\mathrm{K}_{\mathrm{dgc}, g=0}$ are appreciably easier to acquire. Additional data regarding the gravel-correction can be found in Appendix A.

The $\mathrm{K}_{\mathrm{dgc}, \mathrm{g}=0}$ will be used to correct for the conservative case "empirical" $\mathrm{K}_{d}$ values in the graveldominated sequence (described in more detail below) and is defined as:

$$
K_{d g c, g=0}=(1-g) K_{d<2 m m},
$$

where $g$ is the gravel weight fraction of sediment in the field and $K_{d<2 m m}$ is the traditional $K_{d}$ value measured using the $<2-\mathrm{mm}$ fraction. Equation 6 greatly improves the accuracy of the "empirical" $\mathrm{K}_{\mathrm{d}}$ construct for Hanford Site sediments and, perhaps more important from the standpoint of the ILAW PA, it provides in all cases a more conservative $\mathrm{K}_{d}$ value than the traditional $\mathrm{K}_{\mathrm{d} \times 2 \mathrm{~mm}}$ commonly used in such calculations.

\subsection{Moisture Dependency of $K_{d}$ Values}

The moisture dependency of $\mathrm{K}_{d}$ values has been and continues to be evaluated by our group (Lindenmeier et al. 1995, Kaplan et al. 1996, Gamerdinger et al. 1998). Based on our findings to date, as well as the literature, our belief on this subject is that there is a slight decrease in $U(V I)-K_{d}$ values as the moisture content in a system decreases. In support of this contention is that four of the five sediments tested to date showed this trend. The sediment that did not show this trend had only two $\mathrm{K}_{d}$ data points, one from a saturated system and the other from an unsaturated system (Kaplan et al. 1996). This decrease in $K_{d}$ for U[VI]) as percent saturation decreased may be attributed to the fact that as the degree of saturation decreases, solutes come into contact with fewer exchange sites. But with more contact time between the vadose zone sediments and the porewater, diffusion processes may allow the contaminants to interact with sediment adsorption sites that are "hidden" in dead-end pore spaces. The dead-end pore spaces may be created during the laboratory flow-through column experiments performed at unsaturated moisture contents, although they also occur in nature as determined in some field studies. That is, the slight dependency (decrease in $\mathrm{K}_{d}$ for U[VD) of $\mathrm{K}_{d}$ as percent saturation decreased may be caused by a physical process, which will become less important in the field, than a chemical process. An alternative explanation is that higher ionic-strength fluid exists in the double layer of partially saturated sediments leading to weaker sorption. This latter explanation is less likely since the double layer around particle surfaces reach only nanometers into the water, whereas the uniform film thickness of pore fluid around unsaturated Hanford Site sediments is estimated to be several micrometers (see Appendix $\mathrm{C}$ for a short discussion). For the 2001 ILAW PA we will ignore the $\mathrm{K}_{d}$ dependency on moisture content and use the $\mathrm{K}_{\mathrm{d}}$ values measured in traditional saturated tests. If the flow models used in the future PAs

To account for a possible moisture dependency of $\mathrm{K}_{\mathrm{d}}$ values, all $\mathrm{K}_{\mathrm{d}}$ estimates assigned to the vadose zone will be slightly lower than values derived from traditional tests conducted in saturated systems. 
(beyond the 2001 ILAW PA) are capable of modeling the mobile-immobile water concepts presented in van Genuchten (1981), then the effect of moisture content on the retardation factor can be accommodated without altering the $\mathrm{K}_{d}$ value. Consequently, all $\mathrm{K}_{d}$ estimates used in the future $P A s$ for the vadose zone would be slightly lower than values derived from traditional tests conducted in saturated systems. We will also continue studies on the effects of partial saturation on the $\mathrm{K}_{\mathrm{d}}$ of $\mathrm{U}(\mathrm{VI})$ for one more year in hopes of resolving the issue.

\subsection{Colloid-Facilitated Transport of Contaminants}

Contaminant transport is traditionally modeled as a two-phase system: a mobile aqueous phase and an immobile solid phase. Over the last 15 years, there has been an increasing awareness of a third, mobile solid phase. This mobile solid phase, mobile colloids, consists of organic and/or inorganic submicron particles that move with groundwater flow. When radionuclides are associated with colloids, the net effect is that radionuclides can move faster through the system than would be predicted on the basis of reversible sorption. It is not known whether colloids in the subsurface environment of the Hanford Site enhance contaminant transport. Furthermore, it is not known if mobile colloids in a plume emanating from the ILAW waste site will have significant effects on contaminant transport rates.

Mobile colloid formation is commonly described as a three-step process: genesis, stabilization, and transport. Colloid genesis describes how the submicron particles are formed in groundwater. Stabilization describes how the colloids are brought into suspension, which is a function of the colloid and groundwater composition and water flow forces. Transport describes how the suspended colloids move through the porous media or are retained by physical forces, such as diffusion, straining, or gravitational settling, or physicochemical attraction to the matrix.

Regarding the first step, colloid genesis, there is little doubt that radionuclide-bearing colloids will be generated at the ILAW disposal site. Ramsay (1988) presented strong evidence for the existence of colloid particles in glass and cement leachate and provided an in-depth review of the various types of colloids that can/may exist (e.g., glass fragments, precipitation products, geological materials, secondary phases formed from glass leachate). However, based on experiments using Hanford Site groundwater and colloids, there is little likelihood that colloids would remain suspended in

There is little doubt that colloids with radionuclides associated with them will be generated at the disposal site. However, there is little likelihood that colloids would remain in suspension in glass leachate, cement leachate, or even uncontaminated Hanford groundwater because of the high ionic strength of these waters. This would minimize colloid-facilitated transport of radionuclides from the disposal site. glass leachate, cement leachate, or Hanford groundwater (McGraw and Kaplan 1997). The ionic strength of these solutions greatly exceed the critical flocculation concentration (the minimum electrolyte concentration to induce colloid flocculation) of most particles. Even in uncontaminated Hanford groundwater, where the ionic strength would be at its lowest, the critical flocculation concentration is likely exceeded by $300 \%$ to $600 \%$, depending on the type of colloid in suspension. This would minimize colloidfacilitated transport of radionuclides from the disposal site. Hence, colloid-facilitated transport of contaminants will not be considered as an important transport process in the ILAW PA until there is compelling evidence that our assessment is flawed. 


\subsection{Geochemistry of Key Radionuclides}

This chapter provides a brief description of the geochemistry of radionuclides identified by preliminary subsurface transport simulations as presenting the greatest health risks. Emphasis is placed on describing the chemical processes relevant to the Hanford Site's unsaturated zone, which is a coarse sand-textured, alkaline sediment with low natural organic matter concentrations. Geochemical information relevant to other environments, such as reducing environments, is also provided to address possible near-field systems and a possible localized stagnant silt/mud region in the upper unconfined aquifer.

\subsection{Iodine}

There are 24 known isotopes of iodine, 18 of these having half-lives of $<1$ day. The only stable isotope is

${ }^{127} \mathrm{I}$. Its average natural abundance in geologic materials is $5 \mathrm{mg} / \mathrm{kg}$ ( $\mathrm{Gu}$ and Schulz 1991) and its concentration in uncontaminated surface waters is typically $<1 \mathrm{mg} / \mathrm{L}$ (Stumm and Morgan 1981). The isotope of concern for long-term disposal at the Hanford Site is ${ }^{129} \mathrm{I}$, which has a half-life of $1.7 \times 10^{7}$ years.

\subsubsection{Aqueous Speciation}

Iodine usually exists in freshwater in the minus one oxidation state as iodide (I) (Whitehead 1984). In alkaline and marine environments, iodine usually exists in the VII oxidation state as iodate $\left(\mathrm{IO}_{3}{ }^{-}\right)$ (Whitehead 1984). Iodide and $\mathrm{IO}_{3}{ }^{-}$were the most commonly detected species in rainwater collected after the Chernobyl accident (Muramatsu et al. 1990). The other oxidation states of iodine, III and V, are much less frequently found in nature. Iodide is likely to be the dominant iodine species in the Hanford Site's upper unconfined aquifer because its domain of predominance extends throughout the $\mathrm{pH}$ scale, completely covering a large part of the stability domain of water (Figure 1; Ticknor and Cho 1990). Oxidation of $\mathrm{I}_{2}$ to produce $\mathrm{IO}_{3}^{-}$, the second most abundant form of iodine in aqueous systems, is easily accomplished in basic solution by the reaction:

$$
3 \mathrm{I}_{2}+6 \mathrm{OH}^{-}=5 \mathrm{I}^{-}+\mathrm{IO}_{3}^{-}+3 \mathrm{H}_{2} \mathrm{O}
$$

(Cotton and Wilkinson 1972). Thus, the $\mathrm{IO}_{3}^{-}$form of iodine is likely dominant in well-oxidized, high-pH systems as may exist in the near field of the $\mathrm{LAW}$ disposal site. Iodide and $\mathrm{IO}_{3}^{-}$tend to exist as free ions, but the complexes they do form are generally the most soluble of all halide complexes.

\subsubsection{Precipitation and Coprecipitation}

Precipitation of iodide compounds is not likely to be a dominant reaction path for iodide in the glass leachate. Iodide, in comparison with the other halides, forms especially weak complexes with metal ions as a result of its large size $\left(0.22-\mathrm{nm}\right.$ ionic radius, Langmuir 1979). The metals with which $\mathrm{I}^{-}$and $\mathrm{IO}_{3}^{-}$ form sparingly soluble compounds, $\mathrm{Ag}, \mathrm{Ba}, \mathrm{Hg}, \mathrm{Pb}$, and $\mathrm{Pd}$ (Pourbaix 1966) exist in nature at very low concentrations. The low concentrations of iodine in the contaminant plume will likely exist as either free species or as highly soluble complex species. However we are finding that the weathering products of glass, zeolites and clays, do seem to incorporate several anionic contaminants, including pertechnetate, 


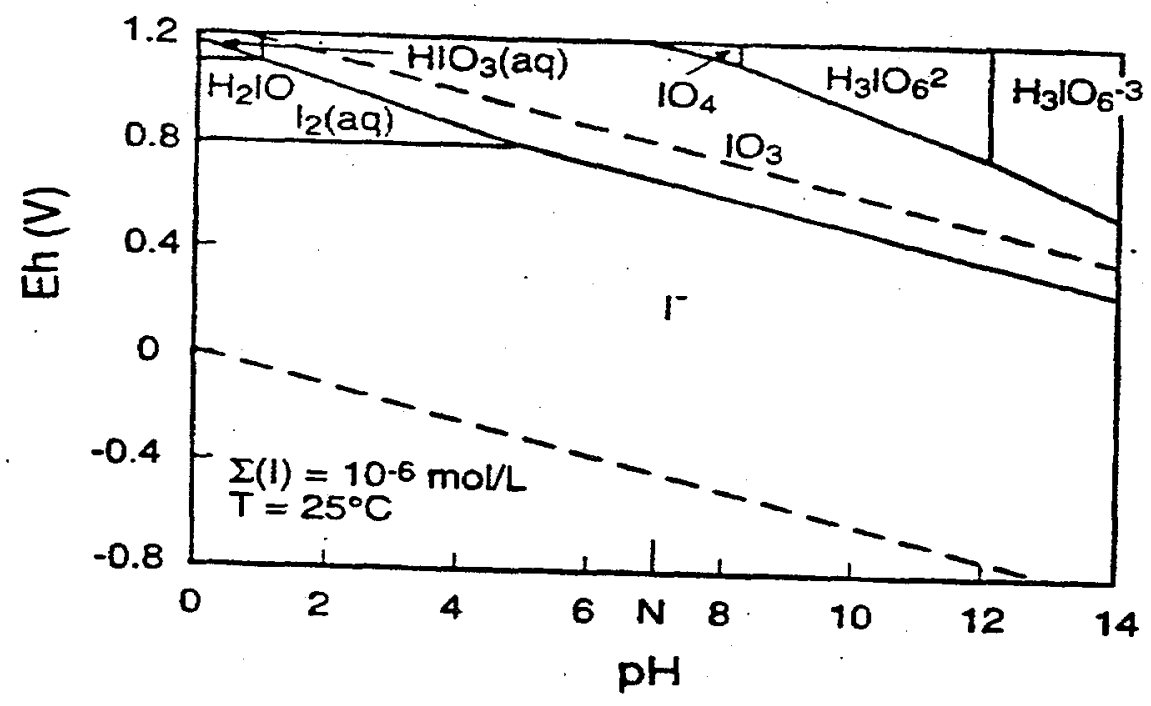

Figure 1. Eh and pH Diagram for Iodine/Water System (Ticknor and Cho 1990)

$\mathrm{Se}$, and I (it is not clear whether the species is $\mathrm{I}^{-}$or $\mathrm{IO}_{3}{ }^{-}$at this time). Results will be published in a progress report in early fiscal year 2000. Past progress that describes preliminary tests is found in Mattigod et al. 1998. At this time, we will not include this apparent co-precipitation or specific adsorption (see below) of iodine leached from the glass into or onto the zeolites and clays that form in transport calculations or the geochemical data package for the 2001 ILAW PA. This will build in a degree of conservatism that will be dealt with (removed) when quantitative data on co-precipitation is available certainly by the time that the 2003 ILAW PA is scheduled.

\subsubsection{Sorption}

Two types of reactions between anions and inorganic solids are recognized: specific adsorption and nonspecific adsorption. Specific adsorption refers to incorporation of anions as a ligand in the coordination shell of an adsorbent, while nonspecific adsorption refers to adsorption of anions by simple coloumbic (electrostatic) interactions with positive charges. Iodine anions are believed to sorb primarily through nonspecific, anion-exchange reactions on mineral surfaces (Gu and Schulz 1991) and through specific adsorption on organic substances (Walters and Winchester 1971). Nonspecific sorption may occur at the localized positive charges that occur on 1) Fe and Al oxide surfaces, 2) edges of aluminosilicate clay surfaces where the oxygen atoms are not fully coordinated by $\mathrm{Al}$ or Si atoms, and 3) on amine and amino groups of organic substances. These positive charges, which increase with decreasing $\mathrm{pH}$, attract anions electrostatically. Whitehead (1973), for example, reported that sorption of I by soils was associated with both soil organic matter and $\mathrm{Fe}$ and $\mathrm{Al}$ oxides, with the oxides increasingly important under more acidic conditions. The maximum amounts sorbed by two surfaces occurred at $\mathrm{pH} 6.6$. At this $\mathrm{pH}$, the amounts of I sorbed were found to be closely related to the contents of organic matter but not to $\mathrm{Fe}$ or $\mathrm{Al}$ oxides or clay. At $\mathrm{pH}<5$, the removal of $\mathrm{Fe}$ and $\mathrm{Al}$ oxides resulted in a marked reduction in $\mathrm{I}^{-}$ sorption. Whitehead (1974) further observed that freshly precipitated ferric and Al oxides sorbed substantial amounts of $\mathrm{I}$ from solutions of $\mathrm{pH}<5.5$ but the amount decreased to zero as the $\mathrm{pH}$ approached 7 . Presumably, this trend reflects the presence of an increasing amount of positive charge (anion-exchange capacity) on the amphoteric oxide surfaces at lower $\mathrm{pH}$ levels. 
Ticknor and Cho (1990) studied the interaction of $\mathrm{I}^{\mathrm{C}}$ and $\mathrm{IO}_{3}^{-}$over a $\mathrm{pH}$ range of 7.5 to 8.0 with a number of minerals including calcite, chlorite, epidote, goethite, gypsum, hematite, kaolinite, bentonite, muscovite, and quartz. No I sorption was detected from any of the solutions on any of the minerals. Iodate was removed from solution to a somewhat greater extent then $I^{-}$. Bentonite, calcite, gypsum, and muscovite adsorbed no $\mathrm{IO}_{3}{ }^{-}$. Muramatsu et al. (1990) reported that neither $\mathrm{I}^{-}$nor $\mathrm{IO}_{3}{ }^{-}$sorbed to quartz sand. We concluded that the low $\mathrm{I}^{-}$and $\mathrm{IO}_{3}^{-}$sorption was the result of the low anion-exchange capacities of the minerals at the high $\mathrm{pH}$ of the systems investigated. Recently, Kaplan et al. (1999) showed that some naturally occurring 2:1 phyllosilicate minerals have the ability to sorb large amounts of iodide. $\mathrm{K}_{\mathrm{d}}$ values $>60 \mathrm{~mL} / \mathrm{g}$ were measured for illites. Nlite generally accounts for $\sim 20 \%$ of the clay fraction of Hanford Site sediments. Even at $\mathrm{pH}>9$, iodide $\mathrm{K}_{d}$ values for these illites were $>20 \mathrm{~mL} / \mathrm{g}$. Subsurface Hanford sediment with a pH of 8 had $\mathrm{K}_{\mathrm{d}}$ values that average $3 \mathrm{~mL} / \mathrm{g}$ and ranged from 0.1 to $10 \mathrm{~mL} / \mathrm{g}$.

\subsection{Neptunium}

There are 16 known isotopes of $\mathrm{Np}$ from ${ }^{228} \mathrm{~Np}$ to ${ }^{241} \mathrm{~Np}$ (Keller 1971). Only ${ }^{237} \mathrm{~Np}$, a neutron reactor product of ${ }^{238} \mathrm{~Np}(\mathrm{n}, 2 \mathrm{n})$, and ${ }^{235} \mathrm{~Np}(\mathrm{n}, \gamma)$, with a half-life of $2.14 \times 10^{6}$ years, are of interest to the ILAW PA.

\subsubsection{Aqueous Speciation}

Neptunium exists in aqueous solutions in five oxidation states, $N p(I I I), N p(I V), N p(V), N p(V I)$, and $\mathrm{Np}$ (VII). In the absence of complexing agents, the first four oxidation states exist as hydrated ions $\mathrm{Np}^{+3}-$ $\mathrm{H}_{2} \mathrm{O}, \mathrm{Np}^{+4}-\mathrm{H}_{2} \mathrm{O}, \mathrm{NpO}_{2}{ }^{+}-\mathrm{H}_{2} \mathrm{O}, \mathrm{NpO}_{2}{ }^{+2}-\mathrm{H}_{2} \mathrm{O}$ (Ames and Rai 1978). $\mathrm{Np}$ (VII) is a strong oxidizing agent that is stable in strong alkaline solution as $\mathrm{NpO}_{5}^{-3}$. Between $\mathrm{pH} 0$ to $9, \mathrm{NpO}_{2}{ }^{+}$is the common $\mathrm{Np}$ species formed in aqueous environments (Ames and Rai 1978). Above $\mathrm{pH} 9$ (and $>100 \mathrm{mg} / \mathrm{L}$ carbonate) an uncharged bicarbonate complex is formed. According to Keller (1971), $\mathrm{Np}(\mathrm{V})$ does not form hydroxide complexes below pH of 7 . $\mathrm{Np}(\mathrm{V})$ exists as the singly charged neptunyl ion, $\mathrm{NpO}_{2}{ }^{+}$, with symmetrical linear bonding $(\mathrm{O}-\mathrm{Np}-\mathrm{O})^{+}$. It hydrolyzes only at a $\mathrm{pH}>7$, disproportionates only at high-acid concentrations, and forms no polynuclear complexes (Keller 1971). $\mathrm{NpO}_{2}{ }^{+}$ion complexes only weakly with inorganic ligands.

\subsubsection{Precipitation and Coprecipitation}

In an oxidizing environment, $\mathrm{Np}$ solids in an increasing order of stability are $\mathrm{Np}(\mathrm{OH})_{4}, \mathrm{NpO}_{2}$, $\mathrm{NpO}_{2}(\mathrm{OH})_{2}$. Because $\mathrm{NpO}_{2}$ can maintain a very high concentration of $\mathrm{Np}$ in solution, it is unlikely that $\mathrm{NpO}_{2}$ would be found as a discrete solid in terrestrial environments. It may exist in very reducing conditions as a solid.

\subsubsection{Sorption}

A singly charged neptunyl ion, $\mathrm{NpO}_{2}^{+}$, is likely the dominant species of $\mathrm{Np}$ in the oxidizing environment of the Hanford Site vadose zone (Ames and Rai 1978). $\mathrm{NpO}_{2}^{+}$does not compete favorably with $\mathrm{Ca}^{2+}$ and other common divalent ions for adsorption sites on sediments; consequently, $\mathrm{Np}-\mathrm{K}_{\mathrm{d}}$ values are

A singly charged neptunyl ion, $\mathrm{NpO}_{2}{ }^{+}$, is likely the dominant species in the oxidizing environment of the Hanford vadose zone. Neptunyl sorbs poorly to most minerals. 
usually relatively low (Routson et at. 1976, Sheppard et al. 1976). Benson (1961) examined Np sorption to 25 common sulfide, silicate, and carbonate minerals using trace amounts of Np in Columbia River water at $80^{\circ} \mathrm{C}$. Neptunium was adsorbed poorly or not at all by the minerals tested. Robertson (1974) determined the speciation of $\mathrm{Np}$ in the cooling water effluent from $\mathrm{N}$ Reactor. Through the use of ultrafiltration and cation- and anion-exchange resins, the following distribution was observed: $25 \%$ particulate, $70 \%$ cationic, $<3 \%$ anionic, and $<1 \%$ non-ionic. The fact that $\mathrm{Np}$ may become associated with a particulate phase may have significant ramifications regarding the potential role of subsurface mobile colloids in enhancing contaminant transport. A few studies have been conducted to evaluate the propensity of Np to adsorb to Hanford sediments (Rouston et al. 1976, Serne et al. 1993). Their results suggest low-to-moderate adsorption and are included in this data package.

\subsection{Selenium}

${ }^{79} \mathrm{Se}$ is a long-lived fission product whose half-life is not well established. One estimate is $6.5 \times 10^{4}$ years but the value may be as much as 10 times larger. ILAW is monitoring efforts to resolve the half-life issue. ${ }^{79} \mathrm{Se}$ is commonly found as a fission product in spent fuel elements. The stable, nonradioactive form of Se is ubiquitous, especially in the westem U.S. sediments. After nonradioactive Se was found to be the cause of reduced fecundity of migrating birds in the mid-1980s, much research was directed at understanding the environmental fate of Se.

\subsubsection{Aqueous Speciation}

Selenium exists in natural aqueous environments in $-2,+4$, and +6 valence states. Most of the Se species in natural waters exist as anions: selenate [Se(VI)] or selenite [Se(IV)]. Under reducing conditions, $\mathrm{H}_{2} \mathrm{Se}^{0}$ would dominate below $\mathrm{pH} \mathrm{3:8}$ and $\mathrm{HSe}^{-}$would dominate above $\mathrm{pH} 3.8$ (Rai and Zachara 1984). The selenite species would predominate under intermediate to slightly oxidizing conditions. Highly oxidizing conditions ( $\mathrm{pe}+\mathrm{pH}>15$ ) are necessary for $\mathrm{SeO}_{4}{ }^{2-}$ to form to a significant extent. Selenate and selenite may form ion-pair species with $\mathrm{Ca}^{2+}$. Solid phases in order of increasing solubility are $\mathrm{FeSe}_{2}$, FeSe, and CuSe (Rai and Zachara 1984). However, the solubility products, $\mathrm{K}_{\text {sp }}$, for $\mathrm{FeSe}_{2}$ or the other compounds are not well defined.

\subsubsection{Precipitation and Coprecipitation}

Although several solid phases, such as $\mathrm{FeSe}_{2}$, are predicted to be stable under relatively reducing conditions, and some studies indicate precipitation may be occurring, no definitive information on solubilitycontrolling solids is available. $\mathrm{Fe}(\mathrm{OH})_{4} \mathrm{SeO}_{3}$ was proposed (Geering et al. 1968) to help explain the insolubility of $\mathrm{Se}$ in soils as well as the strong association of $\mathrm{Se}$ with $\mathrm{Fe}$ in precipitates. Benjamin and Bloom (1981) observed that metal ion adsorption onto amorphous iron oxyhydroxides was enhanced in the presence of an Fe-Se solid phase adsorbed on the oxyhydroxide surface. Benjamin and Bloom (1981) observed that selenite was irreversibly adsorbed on crystalline iron oxide surfaces (goethite, hematite). As mentioned in the iodine section, recent laboratory tests where glass doped with anionic forms of Se, I, and $\mathrm{TC}$ were weathered in water show that significant masses of these elements are incorporated into secondary minerals (clays and zeolites) that form. Thus ignoring co-precipitation and/or specific adsorption of these elements in the vault region may significantly overestimate the transport and dose calculations in the 2001 LAW PA. However, until we gain a better understanding of the glass weathering 
products, their long-term stability, and the incorporation process(es), we will not take credit for these retention processes until the 2003 ILAW PA.

\subsubsection{Sorption}

Laboratory studies indicate that, in spite of their anionic nature, selenite and selenate may be adsorbed significantly by some soils. The experimental evidence suggests that crypto-crystalline and amorphous forms of $\mathrm{SiO}_{2}, \mathrm{Al}_{2} \mathrm{O}_{3}$, and $\mathrm{Fe}_{2} \mathrm{O}_{3}$ control $\mathrm{Se}$ adsorption (John et al. 1976, Singh et al. 1981). Studies with pure mineral phases demonstrate that hydrous oxides of $\mathrm{Fe}$ and $\mathrm{Al}$ and amorphous

Though selenite $\left(\mathrm{pK}_{2}: 7.9\right)$ and selenate $\left(\mathrm{pK}_{2}: 1.7\right)$ differ appreciably in their acidity, little difference is seen in their adsorption by soil. aluminosilicates have a high affinity for Se(IV, VI) (Leckie et al. 1980, Hingston et al. 1968), which significantly exceeds that of layer lattice silicates (Frost and Griffin 1977, Hamby and Gissel-Nelson 1977, Singh et al. 1981). Selenate may be adsorbed more strongly by clay minerals than selenite (Frost and Griffin 1977), while the inverse applies to hydrous oxides of Fe (Leckie et al. 1980, Benjamin and Bloom 1981).

The adsorption of Se(IV) and Se(VI) on goethite, amorphous iron oxyhydroxide, and gibbsite is strongly pH dependent (Hingston et al. 1968, 1972 Leckie et al. 1980): The anions are strongly sorbed under acidic conditions, but sorption decreases with increasing $\mathrm{pH}$. Limited experimental evidence suggests that, at a given $\mathrm{pH}$, Se adsorbs to neutral and positively charged amphoteric oxide surfaces displacing water, hydroxyls, and other adsorbed ligands (e.g., sulfate, silicate) until the surface is neutral in charge (Rajan 1979).

The presence of competing anions may reduce Se(IV) and Se(VI) adsorption by using limited ligandexchange sites and reducing surface net positive charge. Phosphate reduces Se adsorption on goethite, though some sites are specific to $\mathrm{Se}$ (Hingston et al. 1971). Sulfate reduces $\mathrm{SeO}_{4}{ }^{2-}$ adsorption on amorphous iron oxyhydroxides in a manner consistent with the competitive Langmuir equation (Leckie et al. 1980). The Se adsorption tests using Hanford Site-specific sediments and groundwater/alkaline leachates are described in this data package.

\subsection{Technetium}

All isotopes of Tc are radioactive. Several $T c$ isotopes are obtained by the fissioning of nuclear fuels of $U$ in the reactor. The $\mathrm{Tc}$ isotopes and their yields resulting from $\mathrm{U}$ fission include: ${ }^{99} \mathrm{Tc}, 6.06 \% ;{ }^{101} \mathrm{Tc}$, $5.6 \% ;{ }^{102} \mathrm{Tc}, 4.3 \% ;{ }^{103} \mathrm{Tc}, 3.0 \% ;{ }^{104} \mathrm{Tc}, 1.8 \% ;{ }^{105} \mathrm{Tc}, 0.9 \%$; and ${ }^{106} \mathrm{Tc}, 0.19 \%$. Of these fission products, only ${ }^{99} \mathrm{Tc}$ is a potential hazard from long-term burial of ILAW, because this isotope has a long half-life $\left(2.12 \times 10^{5}\right.$ years $)$.

\subsubsection{Aqueous Speciation}

Technetium exists in valence states from (VII) to (-I). The most stable and characteristic oxidation state of Tc in slightly acid, neutral, or basic aqueous solutions in equilibrium with the atmosphere is pertechnetate ion $\left(\mathrm{TcO}_{4}{ }^{-}\right)$in which Tc is in the heptavalent state (Coughtrey et al. 1983, Hanke et al. 1986). Various $\mathrm{Tc}(\mathrm{V}), \mathrm{Tc}(\mathrm{IV})$, or $\mathrm{Tc}(\mathrm{III})$ species may be formed under reduced conditions (Pilkington 1990). However, the most stable of these reduced oxidation states is generally $\mathrm{Tc}$ (IV) (Bondietti and Francis 
1979). The nature of the $\mathrm{Tc}(\mathrm{IV})$ species is uncertain: the most common species is $\mathrm{TcO}_{2}(\mathrm{~s})$ (Bondietti and Francis 1979, Gu and Schulz 1991). The reduced Tc species are rapidly oxidized to Tc(VII) by atmospheric oxygen (Coughtrey et al. 1983), and, therefore, regardless of the oxidation state of the Tc emanating from the near field, it is likely to be in the (VII) oxidation state once it reaches the far field.

Pertechnetate ion is highly soluble (Baes and Mesmer 1976, Pilkington 1990). In alkaline solutions and a low redox potential, the $\mathrm{Tc}(\mathrm{IV})$ species are more prevalent and its complexes are typically much less soluble, on the order of $10^{-7}$ to $10^{-8} \mathrm{~mol} \mathrm{~L}^{-1}$ over a range from $\mathrm{pH} 4$ to 10 (Pilkington 1990). The solubility of Tc in contact with hydrated $\mathrm{TcO}_{2}$ was investigated by Pilkington (1990). He found that $\mathrm{pH}$ had little effect on measured solubility of $\mathrm{Tc}$ over the $\mathrm{pH}$ range of 1 to 12.5 . However, the presence of organic materials increased the measured solubility of $\mathrm{Tc}$ by a factor of 10 , indicating that complexation between the dissolved organic materials and the Tc is important. Wildung et al. (1986) suggested that low molecular weight organic ligands may increase the solubility of reduced forms of $\mathrm{Tc}$, whereas complexation with the high molecular weight organic ligands, particularly insoluble organic ligands, may lead to precipitation. Schulte and Scoppa (1987) showed that Tc(IV) had a strong tendency to coordinate with ligands containing highly polar groups and negatively charged ligands.

\subsubsection{Precipitation and Coprecipitation}

Precipitation of $\mathrm{TcO}_{4}{ }^{-}$- containing solids is not likely to be an important geochemical process affecting ${ }^{99} \mathrm{Tc}$ transport through the Hanford Site vadose zone. Technetium(VII) forms very soluble oxides and halide complexes (Baes and Mesmer 1976). However, if Tc(VII) is reduced to Tc(IV) in the near field, it may form a number of sparingly insoluble complexes, such as $\mathrm{TcO}_{2}$ or $\mathrm{Tc}$ sulfide solids. As mentioned above, the glass weathering products formed in the short- term lab tests sequester significant amounts of Tc present in the glass as the pertechnetate species. Thus ignoring this removal process in the 2001 ILAW PA would appear to be adding a level of conservatism to the final predictions.

\subsubsection{Sorption}

A number of studies have shown that retention of $\mathrm{Tc}$ by solid phases is related to the physicochemical properties of the solid phase (reviewed by Ames and Rai 1978, Gu and Schulz 1991). These studies indicate that systems containing low amounts of clay, organic carbon, and $\mathrm{Al} / \mathrm{Fe}$ oxides show very little adsorption. Bowen (1966) reported that in oxic conditions, $90 \%$ of added $\mathrm{TcO}_{4}{ }^{-}$was readily extractable from soils and assumed to remain in solution either as the free ion or weakly adsorbed to ion-exchange sites. Similarly, Wildung et al. (1977) reported that under oxic conditions, 78 to $88 \%$ of the $\mathrm{TcO}_{4}{ }^{-}$added to the soil could be extracted easily 30 days after application. Under anaerobic conditions, Cataldo et al. (1978) reported that Tc removal from solution by soils could exceed $97 \%$ in 2 to 5 weeks.

In a study of 7 mineral soils and 27 organic soils, Sheppard et al. (1990) reported that in addition to the redox status, the organic matter content of soils plays an important role in Tc sorption. Evidence of the complexation between organic materials and Tc has also been presented by Van Loon et al. (1986). They indicated that such complexes can be readily synthesized by chemical reduction of pertechnetate in the presence of organic matter.

Reduced $T c$ precipitates or organic matter-Tc complexes are not resolubilized by the chelating agents, EDTA and DTPA, which are known to form stable Tc complexes (Stalmans et al. 1986). This would 
indicate that EDTA and DTPA complexes are not as strong as the Tc organic matter complexes, suggesting that naturally occurring organic matter may play a significant role in $\mathrm{Tc}$ transport by forming relatively stable Tc complexes. Whether these complexes are soluble or insoluble depends on the size of the organic ligand. It is not known whether the organic matter - Tc(IV) complexation reaction - can favorably compete with $\mathrm{Tc}(\mathrm{IV})$ hydrolysis reactions.

Retention of $\mathrm{Tc}$ is largely determined by the oxidation states of the system as a result of the vast difference in the solubility between $\mathrm{Tc}(\mathrm{VI})$ and Tc(IV) containing compounds; Tc(VII) is retained appreciably less than Tc(IV).

Many adsorption studies with Hanford Site sediments and waters under oxidizing conditions have been performed and they generally show no adsorption of the pertechnetate anion. Specifics are found in this data package mainly in the tables found in Chapter 5.0.

\subsection{Uranium}

The natural abundance of uranium in geologic matter is $\sim 3 \mathrm{mg} / \mathrm{kg}$ (Ames and Rai 1978). Naturally occurring uranium typically contains $99.283 \%{ }^{238} \mathrm{U}, 0.711 \%{ }^{235} \mathrm{U}$, and $0.0054 \%{ }^{234} \mathrm{U}$ by weight. Geologically, uranium occurs as U(IV) in minerals, such as pitchblende, uraninite, carnotite, autunite, and as U(VI) in uranophane. It is also found in phosphate rock, lignite, and monazite sands at levels that can be commercially recovered. In the presence of lignite and other sedimentary carbonaceous substances, uranium enrichment in nature is believed to be the result of its reduction to form insoluble precipitates, such as uraninite. The isotopes of interest in waste disposal and their respective half-lives include ${ }^{233} \mathrm{U}$, 162,000 years; ${ }^{234} \mathrm{U}, 247,000$ years; ${ }^{235} \mathrm{U}, 7.13 \times 10^{8}$ years; ${ }^{236} \mathrm{U}, 2.39 \times 10^{7}$ years; and ${ }^{238} \mathrm{U}, 4.51 \mathrm{x}$ $10^{9}$ years.

\subsubsection{Aqueous Speciation}

Uranium can exist in the (III), (IV), (V), and (VI) oxidation states. The aqueous U(VI) uranyl cation $\left(\mathrm{UO}_{2}{ }^{2+}\right)$ is the most stable ion in oxidizing solutions. The U(III) species easily oxidizes to U(IV) under most reducing environmental conditions, while the $U(\mathrm{~V})$ aqueous species $\left(\mathrm{UO}_{2}{ }^{+}\right)$readily disproportionates to U(IV) and U(VI). In aqueous systems, U(IV) species will not be present to any great extent as a result of the low solubilities of $\mathrm{U}(\mathrm{IV})$ species, such as uraninite $\left(\mathrm{UO}_{2}\right)$ or some other solids with $\mathrm{O} / \mathrm{U}$ ratios between 2.3 and 2.7 (Bruno et al. 1988, 1991). Average uranium concentrations in natural waters under reducing conditions are between 3 and $30 \mathrm{ppb}$ (Bruno et al. 1991); this is consistent with equilibrium concentrations controlled by $\mathrm{UO}_{2}$ (s) (Bruno et al. 1988). In the absence of complexing agents, $\mathrm{U}(\mathrm{VV})$ is expected to hydrolyze to form mononuclear hydroxo complexes, $\mathrm{U}(\mathrm{OH})_{\mathrm{n}}{ }^{4-\mathrm{n}}$ (Langmuir 1978). Complexation of $\mathrm{U}(\mathrm{IV})$ actinides with natural organic humic and fulvic acids has been suggested as an important process ( $\log \mathrm{K}=12$ to 16 ; Birch and Bachofen 1990). Hence, U(IV) could form stable organic complexes, increasing the solubility of the U(IV). In general, U(IV) actinide species form stronger organic complexes than do the U(VD) actinide species (Birch and Bachofen 1990).

Aqueous U(VI), or uranyl, $\mathrm{UO}_{2}{ }^{2+}$, tends to form strong complexes with inorganic oxygen-containing ligands, such as hydroxide, carbonate, and phosphate. Aqueous $\mathrm{UO}_{2}{ }^{2+}$, hydrolyzes to form a number of aqueous hydroxo complexes, including $\mathrm{UO}_{2} \mathrm{OH}^{+},\left(\mathrm{UO}_{2}\right)_{2}(\mathrm{OH})_{2}{ }^{2+},\left(\mathrm{UO}_{2}\right)_{3}(\mathrm{OH})_{5}{ }^{+}$, and $\mathrm{UO}_{2}(\mathrm{OH})_{3}{ }^{-}$. In aqueous systems equilibrated with air or higher $\mathrm{pCO}_{2}$ waters at near neutral to high $\mathrm{pH}$, the carbonate complexes $\left[\mathrm{UO}_{2} \mathrm{CO}_{3}{ }^{\circ}, \mathrm{UO}_{2}\left(\mathrm{CO}_{3}\right)_{2}{ }^{2-}, \mathrm{UO}_{2}\left(\mathrm{CO}_{3}\right)_{3}{ }^{4}\right]$ will dominate, but at lower $\mathrm{pH}$ the hydrolysis species 
will dominate as $\mathrm{CO}_{2}$ solubility decreases. Phosphate- $\mathrm{UO}_{2}{ }^{2+}$ complexes $\left(\mathrm{UO}_{2} \mathrm{HPO}_{4}{ }^{\circ}, \mathrm{UO}_{2} \mathrm{PO}_{4}{ }^{-}\right)$could be important in aqueous systems with a pH between 6 and 9 when the total concentration ratio $\left(\mathrm{PO}_{4}{ }^{3-}\right.$ Total. $\left.\mathrm{CO}_{3}{ }^{2-}\right)_{\text {Total }}$ is $10^{-1}$ (Sandino and Bruno 1992 , Langmuir 1978). Complexes with $\mathrm{SO}_{4}{ }^{2-}, \mathrm{F}^{-}$, and possibly $\mathrm{Cl}^{-}$ are potentially important U(VI) species where concentrations of these anions are high. However, their stability is considerably less than that of the carbonate and phosphate complexes (Grenthe 1992). Because of the high hydroxide, high carbonate, and low organic matter concentrations expected in both the near and the far field of the Hanford Site ILAW disposal sites, U(VI) is likely to exist as a complexed carbonate and/or, to a lesser extent, as a hydroxide-complexed species.

\subsubsection{Precipitation and Coprecipitation}

Precipitation or coprecipitation of a solid phase will likely not control the mobility of U(VI) in the farfield vadose zone. However, reduced conditions may be created in the near field that may maintain the waste uranium as a uraninite precipitate, $\mathrm{UO}_{2}(\mathrm{~s})$, (Rai et al. 1990). Uranium is also sequestered in the glass weathering products formed in short-term laboratory experiments, such that coprecipitation reactions in the glass vault should be considered in the 2003 ILAW PA after more quantitative data are available. Besides determining the "loading" capacity of the weathering products for uranium and other contaminants, the long-term stability of the weathering products needs to be established. U(VI) insoluble compounds also appear to control solution concentrations of uranium in cementitious environments (see Brady and Kozak 1995, Krupka and Serne 1998, Serne et al. 1996).

\subsubsection{Sorption}

Uranium is most mobile in oxidizing, carbonate-rich solutions.

Therefore, under these conditions, one would anticipate that uranium would be most soluble. However, other secondary factors may affect the mobility as well. For example, in low-ionic-strength solutions, the uranyl ion concentrations will probably be regulated, in part, by cationexchange adsorption process. The uranyl ion will adsorb onto clays, organics, and oxides, and this will limit its mobility. As the ionic strength of an oxidized solution increases, other ions, notably $\mathrm{Ca}^{2+}$,

The uranyl ion is particularly mobile in high-ionicstrength solutions, such as that expected to exist in the plume emanating from the low-level waste burial site. $\mathrm{Mg}^{2+}$, and $\mathrm{K}^{+}$will displace the uranyl ion, forcing it into solution. Not only will other cations out compete the uranyl ion for exchange sites, but carbonate ions will form strong soluble complexes with the uranyl ion, further lowering its affinity for positively charged solids while increasing the total amount of uranium in solution (Yeh and Tripathi 1991). The anionic uranyl carbonate complexes do not adsorb to the naturally negatively charged Hanford Site sediments at neutral to alkaline $\mathrm{pH}$ conditions.

Some of the sorption processes in which the uranyl ion participates are not completely reversible. Sorption onto iron and manganese oxides can be a major process for extraction of uranium from solution. These oxide phases act as a short-term irreversible sink for uranium in soils. Uranium bound in these phases is not generally in isotopic equilibrium with dissolved uranium in the same system, suggesting that the reaction mediating the transfer of the metal between the two phases is slow.

Solid-phase organics are another possible sink for uranyl ions in soils and to smaller extents in sediments. The mechanisms for uranium sequestration onto organic-rich sediments are numerous and complex. One mechanism may involve sorption of the uranyl cation onto exchange sites, such as carboxylic acid groups. 
These groups can coordinate with the uranyl ion, displacing water of hydration and form stable complexes. A process like this probably accounts for a significant fraction of the organically bound uranium in soils, and perhaps, in sediments. Alternatively, sedimentary organics may reduce dissolved $\mathrm{UO}_{2}{ }^{2+}$ species to U(IV) species. These reduced species are generally low in solubility and may remain associated with the organic phase after precipitation as a reduced oxide. Little seems to be known about the nature of organic uranium associations in soils or sediments on a molecular level, although several different types of interactions may be taking place. The amount of naturally occurring organic substances, such as fulvic and humic acids, is quite low in the subsurface of the Hanford Site. However, there is a possibility that the contaminant plume leaving the near field may contain some organic substances (sulfur polymer cement contains $5 \%$ organic binder and asphalt also may be used in covers). Both of these engineered materials possess some of chemical properties of the organic substances found in natural systems.

Uranium sorption to iron oxides and smectite clay has been shown to be extensive in the absence of $\mathrm{CO}_{3}{ }^{2-}$ (Kent et al. 1988, Hsi and Langmuir 1985, Ames et al. 1982). In the presence of $\mathrm{CO}_{3}{ }^{2-}$ and organic complexants, however, sorption was shown to be substantially reduced or severely inhibited (Hsi and Langmuir 1985, Kent al. 1988, Ames et al. 1982). The importance of U(VI) sorption to inorganic solid phases, such as clays and iron oxides, may be minor in many natural environments because of the limited quantity of these materials and because of the presence of particulate or dissolved organic matter and dissolved carbonate.

Rancon (1973) studied the adsorption of U using four soils and three pure-phase minerals. Quartz was characterized as inert $\left(\mathrm{K}_{\mathrm{d}}=0 \mathrm{~mL} / \mathrm{g}\right)$, calcite was a poor uranium adsorber $\left(\mathrm{K}_{\mathrm{d}}=7 \mathrm{~mL} / \mathrm{g}\right)$, and illite and other $2: 1$ clays $\left(\mathrm{K}_{\mathrm{d}}=139\right.$ to $\left.270 \mathrm{~mL} / \mathrm{g}\right)$ were the best adsorbers of uranium from solution. Acid, organicrich soils showed higher uranium sorption $\left(\mathrm{K}_{d}=33 \mathrm{~mL} / \mathrm{g}\right)$ than soils containing carbonate minerals $\left(\mathrm{K}_{\mathrm{d}}=\right.$ $16 \mathrm{~mL} / \mathrm{g}$ ).

Formation of complexes between U(VI) and organic ligands, such as humic and fulvic particulates, has been studied most frequently because of interest in ore-forming environments. At ambient temperatures $\left(\sim 25^{\circ} \mathrm{C}\right)$, uranium is adsorbed to humic substances through rapid ion-exchange and complexation processes with carboxylic and other acidic functional groups (Idiz et al. 1986, Boggs et al. 1985, Shanbhag and Choppin 1981, Nash et al. 1981, Borovec et al. 1979). The adsorption is often followed by reduction to the U(IV) species followed by precipitation of $\mathrm{UO}_{2}$ (Andreyev and Chumachenko 1964). In studies with lignite, however, the uranyl species formed a stable complex with the lignite without subsequent reduction; reduction only occurred at elevated temperatures (Nakashima et al. 1984). However, organic matter does have the capacity to act as a reductant, most notably because of the presence of quinone, sulfone, and reduced metal porphyrin (tetrapyroles) moieties (Macalady et al. 1986). 


\subsection{Approach}

The geochemical data for both the far field and the near field were organized into five look-up tables, one for each environmental zone that was chosen to represent the ILAW pathway from the glass repository to the Columbia River. The concept and features of these five geochemical zones are presented in Table 1. A schematic representation of the five zones is presented in Figure 2. Each look-up table contains "empirical" $K_{d}$ values and/or solubility data. For each contaminant in each environmental zone, a mostprobable estimate, a reasonable lower-bounding estimate, and a likely range of estimates are provided. The distribution for all contaminant-specific $\mathrm{K}_{\mathrm{d}}$ and solubility parameters is assumed to be log-normal for stochastic modeling. For each data entry, comments and references are provided to support the values.

Whenever possible, the estimates provided in these tables were based on Hanford Site-specific experiments. Generic literature or offsite data was used when site-specific data were not available. Careful selection of generic literature $\mathrm{K}_{\mathrm{d}}$ values was required to ensure that the experi-

Geochemical data will be organized into a number of look-up tables containing $\mathrm{K}_{\mathrm{d}}$ values and/or solubility data for five environmental zones. mental conditions used to generate the $\mathrm{K}_{d}$ values were appropriate for the Hanford-specific zones. Consequently, expert opinion and geochemistry experience were utilized where nonsite-specific data were used; rationale and experimental evidence to support the expert opinion are provided. In some cases, there were no generic data available and we were forced to use "expert judgment" to estimate values. The estimated values that have no actual measurements to defend the choices are marked.

Based on borehole 299-E17-21, the stratigraphy below the ILAW disposal site has two sequences, a sand- . dominated sequence that exists from $\sim 0$ to $75 \mathrm{~m}$ deep and a gravel-dominated sequence that exists from $\sim 75$ to $>475 \mathrm{~m}$ deep (Reidel et al. 1998). The sand-dominated sequence has essentially no gravel, except for a few gravel lenses (Reidel et al. 1998). The gravel-dominated sequence consists of $\sim 90 \%$ gravel. Gravel-corrected $\mathrm{K}_{d}$ values ( $\mathrm{g}$ in Equation $6=0.9$ ) were used for radionuclides in the gravel-dominated layers (zones 4 and 5 in Table 1 ). Little information is available about the properties and distribution of a mud layer that may exist within the gravel-dominated sequence at $\sim 13$ to $30 \mathrm{~m}$ below the water table (125 to $142 \mathrm{~m}$ below ground surface). Unique $\mathrm{K}_{\mathrm{d}}$ values will not be assigned to this potential layer. This is a conservative simplification because reducing (sulfide odor is associated with core samples) clays in this zone likely have a large sorption capacity as a result of a large cation-exchange capacity and surface area and a large potential for reductive precipitation. If this reducing mud layer were found to be present in a large area underneath the ILAW sites, it would warrant more attention, especially for the fate of the highdose redox-sensitive contaminants, such as Tc, $U, N p$, and Se discussed in Chapter 3.0. 
Table 1. Conceptual Features of the Five Geochemical Zones

\begin{tabular}{|c|c|c|c|}
\hline Zone (Data Table) & Solid Phases & Aqueous Phase & $\begin{array}{l}\text { Geo- } \\
\text { chemical } \\
\text { Parameters } \\
\text { Used in } \\
\text { Zone }\end{array}$ \\
\hline $\begin{array}{l}\text { Zone } 1-\text { Near } \\
\text { Field (Table 2) }\end{array}$ & $\begin{array}{l}\text { Glass, secondary phases } \\
\text { formed from glass } \\
\text { degradation, and backfill } \\
\text { and engineered barrier } \\
\text { materials }\end{array}$ & $\begin{array}{l}\text { Glass leachate: high } \mathrm{pH} \text {, high ionic } \\
\text { strength, high radionuclide } \\
\text { concentrations }\end{array}$ & $\begin{array}{l}\mathrm{K}_{\mathrm{d}}, \\
\text { solubility } \\
\text { constraints }\end{array}$ \\
\hline $\begin{array}{l}\text { Zone } 2 \text { - Degraded } \\
\text { Concrete Vault } \\
\text { (Table } 3 \text { ). As of } \\
12 / 01 / 99 \text { this zone } \\
\text { may not be relevant } \\
\text { in future repository } \\
\text { design. }\end{array}$ & $\begin{array}{l}\text { Three assemblages of } \\
\text { minerals will exist, based } \\
\text { on concrete age; fresh } \\
\text { concrete with } \mathrm{pH}=12.5, \\
\text { moderately aged concrete } \\
\text { with pH } \sim 10.5, \text { and com- } \\
\text { pletely aged concrete with } \\
\text { pH } \sim 8.5 . \\
\end{array}$ & $\begin{array}{l}\text { Three types of concrete leachate } \\
\text { chemistries controlled by different } \\
\text { aged solid phases: young concrete } \\
\text { leachate } \mathrm{pH} 12.5 \text {, then } \mathrm{pH} 10.5, \\
\text { final } \mathrm{pH} 8.5 \text {; generally high in ionic } \\
\text { strength and high radionuclide } \\
\text { concentration }\end{array}$ & $\begin{array}{l}\mathrm{K}_{\mathrm{d},} \\
\text { solubility } \\
\text { constraints }\end{array}$ \\
\hline $\begin{array}{l}\text { Zone 3- } \\
\text { Chemically } \\
\text { Impacted Far Field } \\
\text { in Sand Sequence } \\
\text { (Table 4) }\end{array}$ & $\begin{array}{l}\text { Sand-dominated sequence, } \\
\text { slightly altered because of } \\
\text { contact with moderately } \\
\text { caustic aqueous phase }\end{array}$ & $\begin{array}{l}\text { pH } 8 \text { (background) to } 11 \text {, ionic } \\
\text { strength } 0.01 \text { (background) to } 0.1 \text {, } \\
\text { low radionuclide concentration }\end{array}$ & $\mathrm{K}_{\mathrm{d}}$ \\
\hline $\begin{array}{l}\text { Zone } 4- \\
\text { Chemically } \\
\text { Impacted Far.Field } \\
\text { in Gravel Sequence } \\
\text { (Table 5) }\end{array}$ & $\begin{array}{l}\text { Same as zone } 3 \text {, except in } \\
\text { gravel-dominated } \\
\text { sequence }\end{array}$ & $\begin{array}{l}\text { Same as zone } 3 \text {, except in gravel- } \\
\text { dominated sequence }\end{array}$ & $\mathrm{K}_{\mathrm{dgc}}$ \\
\hline $\begin{array}{l}\text { Zone } 5-\text { Far Field } \\
\text { in Gravel Sequence } \\
\text { (Table } 6)\end{array}$ & $\begin{array}{l}\text { Unaltered Hanford Site } \\
\text { gravel sequence }(90 \% \\
\text { gravel, } 10 \%<2 \mathrm{~mm})\end{array}$ & $\begin{array}{l}\text { Unaltered Hanford Site ground- } \\
\text { water, except for trace levels of } \\
\text { radionuclides }\end{array}$ & $\mathrm{K}_{\mathrm{dgc}}$ \\
\hline
\end{tabular}




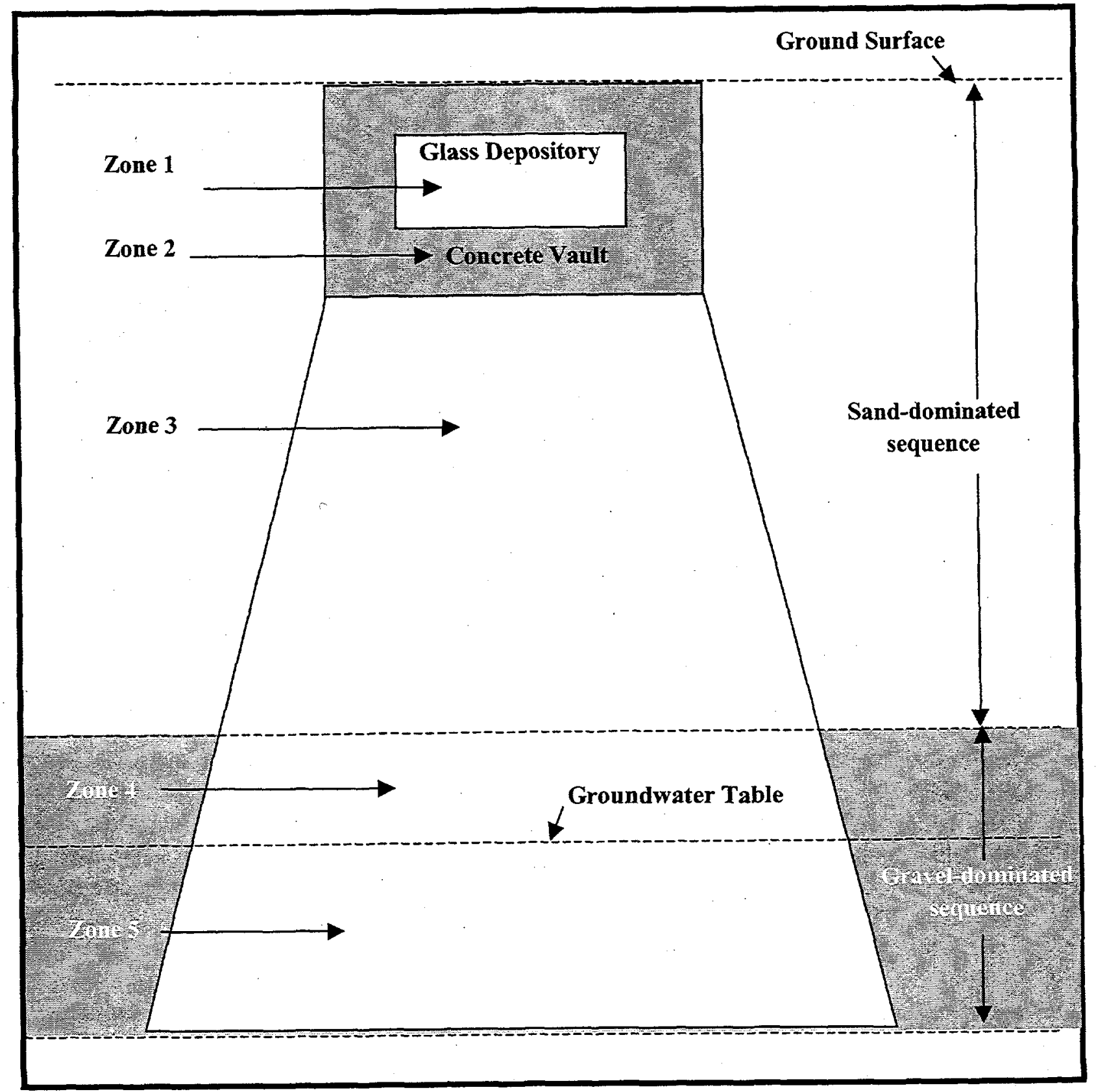

Figure 2. Schematic Representation of the Five Geochemical Zones

The conceptual details of each of the five geochemical zones are described below.

Zone 1-Near Field: The chemistry in this zone is dominated by the presence of glass leachate until all the glass has dissolved. Glass leachate has high $\mathrm{pH}$, ionic strength (especially soluble $\mathrm{Na}$ ), and radionuclide activity. Radionuclide behavior in this zone is affected by unique solid phases dominated by glass, its weathering products, and backfill/engineered barrier materials. Initially, little or no contaminant adsorption will be considered on the glass. As reaction time increases, radionuclides will be incorporated, coprecipitated, into secondary phases formed from glass dissolution. Accounting for these processes will be closely linked with the glass waste-form leaching data package (see McGrail et al. 1999). For the 2001 
ILAW PA, no credit will be taken for the coprecipitation of contaminants into the weathered glass secondary phases because we have not obtained adequate quantitative data for secondary minerals formed on the new British Nuclear Fuels Limited (BNFL) glass formulations. We have also not determined the long-term stability of the weathering products found in the short-term hydrothermal $\left(90^{\circ} \mathrm{C}\right)$ tests. However, it seems clear from past (see Mattigod et al. 1998) and ongoing studies on secondary phases formed from weathering other glass recipes that the coprecipitation process for trace contaminants into the zeolites and clays that form is significant. We have not finished determining how to take the empirical observations and generate mathematical algorithms for inclusion in the near-field transport code. Laboratory studies on determining the nature of the weathering products and trace contaminant sequestration amounts have been under way since early fiscal year 1999 (Mattigod et al. 1998). Adequate data should be available for the 2003 ILAW PA.

Zone 2 -Degraded Concrete Vault: Note that, as of December 1, 1999, the ILAW repository may not include concrete vaults; however, crushed cement may still be used in the near field for $\mathrm{pH}$ control. The chemistry in this zone is dominated by the presence of cement leachate and weathered cement minerals/ compounds, which have high $\mathrm{pH}$, moderate ionic strength, and high-to-moderate radionuclide activity. The cement leachate chemistry will change with time as the concrete degrades and weathers. The assemblage of secondary minerals that form is different from that formed from glass degradation; thus, the radionuclide behavior is expected to differ from zone 1. Zone 2 will also contain backfill materials. The cement weathering times discussed in Krupka and Serne (1998) and Bradbury and Sarott (1995) were used to develop look-up tables for both $\mathrm{K}_{d} \mathrm{~S}$ (onto degraded concrete/aggregate) and solubilities (in concrete porewaters and porewaters from concrete) as a function of time. Three temporal environments are being considered: fresh concrete with $\mathrm{pH} 12.5$, moderately aged concrete with $\mathrm{pH} \sim 10.5$, and completely aged concrete with $\mathrm{pH} \sim 8.5$. It is possible that the glass leachate will maintain a basic $\mathrm{pH}$ condition for tens of thousands of years such that only the first two time-dependent chemistries will be experienced in the ILAW PA system conceptual model. We will rely on the 2001 ILAW PA results to refine the conceptual model for this zone.

The convention of Bradbury and Sarott (1995) for the three types of physicochemical environments that all cements and concretes progress through was used for the development of a preferred database of $\mathrm{K}_{d}$ and solubility constraints. The following text describing the three temporal environments was taken from Krupka and Serne (1998).

Temporal Environment I: This environment occurs immediately after the cement hardens and is wetted by infiltrating water. The cement porewater is characterized as having a high $\mathrm{pH}(>12.5)$, high ionic strength, and high concentrations of potassium and sodium resulting from the dissolution of alkali impurities in the clinker phases. The high concentration of sodium is sometimes augmented by the dissolution of inorganic salts that have been solidified and buried in the disposal facility. Hydration is still continuing during temporal environment I with the formation of C-S-H gel (short hand for the $\mathrm{CaO}-\mathrm{SiO}_{2}-\mathrm{H}_{2} \mathrm{O}$ amorphous material that hardens and constitutes "cement") and portlandite $\left[\mathrm{Ca}(\mathrm{OH})_{2}\right]$. The composition of the cement pore fluid is at equilibrium with portlandite during this time. The duration of temporal environment $I$ is relatively short when compared to the later "environments." Based on the modeling estimates discussed in Berner (1992), this environment may last for the first 100 to 10,000 years.

Temporal Environment II: During this period, the soluble salts of the alkali metals are all dissolved. The $\mathrm{pH}$ of the cement porewater is controlled at a value of 12.5 by the solubility of portlandite. The C-S-H 
and portlandite are the major solid phases present. Temporal environment II may last for a long time, and its duration depends on how much water percolates through the system and the mass of cement present in the concrete structure. The flux of water must dissolve all the slightly soluble portlandite before this environment changes. Using the estimates from Berner (1992), this environment may last from 10010,000 years to $1,000-100,000$ years.

Temporal Environment III: The concentration of portlandite has been reduced to such an extent by this period that the solubility of C-S-H now controls the $\mathrm{pH}$ of the cement pore fluid. The C-S-H starts to dissolve incongruently with a continual decrease in $\mathrm{pH}$. At the end of this evolution, temporal environment III can be conceptualized as leaving only silica $\left(\mathrm{SiO}_{2}\right)$ as the solubility control for the pore fluid $\mathrm{pH}$. The ionic strength of the cement pore fluid during this period is low and its $\mathrm{pH}$ is $\sim 10$ or less. For the sake of simplicity, the final end point of temporal environment III can be considered somewhat analogous to the geochemical conditions of the "normal" ambient soil environment. Of the three "environment" types, the duration of temporal environment $\Pi$ is, thus, the longest in which the pore fluid composition is influenced by the hydration and dissolution reactions of the cement components.

Zone 3-Chemically Impacted Far Field in Sand Sequence: The chemistry in this zone has been impacted by the glass and concrete leachates, such that the porewater has a moderate $\mathrm{pH}$ between 8 (background) and 11, a moderate ionic strength between 0.01 (background) to 0.1 , and low radionuclide activity (below solubility limits). This zone contains moderately altered Hanford formation sediment. This zone starts at the outside edge of the cement vault/engineered barriers and ends at the start of the gravel-dominated sequence (see Figure 2). Contaminants will be controlled primarily by adsorption and not solubility constraints. However, we will consider (for the 2003 ILAW PA) the use of solubility controls in this zone should additional information become available that supports doing so. If the glass leachate and cement/engineered barrier leachates do evolve to less basic and lower ionic-strength chemical solutions at long times, then the $\mathrm{K}_{d}$ values in zone 3 will approach those in Appendix $B$, which shows $\mathrm{K}_{\mathrm{d}}$ values for $<2 \mathrm{~mm}$ sized sediments for natural Hanford Site groundwater.

Zone 4-Chemically Impacted Far Field in Gravel Sequence: The chemistry in this zone has been impacted by the glass and concrete leachate, such that its porewater has a moderate $\mathrm{pH}$ between 8 (background) and 11, a moderate ionic strength between 0.01 (background) to 0.1 , and low radionuclide activity (below solubility limits). This zone exists in the gravel-dominated sequence. The $\mathrm{K}_{d}$ values in this zone will be identical to those for zone 3, except that the $\mathrm{K}_{\mathrm{d}}$ values are gravel corrected. If the glass leachate and cement/engineered barrier leachates do evolve to less basic and lower ionic-strength chemical solutions at long times, then the $\mathrm{K}_{d}$ values in zone 4 will approach those for zone 5 at some time during the PA calculation.

Zone 5 - Far Field in Gravel Sequence: This zone is located below the water table and is in the graveldominated sequence. The groundwater is assumed to dilute the major solutes down to natural background levels. The water in this zone is assumed to be "significantly tainted" only by contaminants and not by major common constituents of the glass and/or cement/backfill leachate. Hanford Site groundwater is dominated by calcium and bicarbonate and has a pH of 8 and an ionic strength of 0.005 to $0.01 \mathrm{M}$. The $\mathrm{K}_{d}$ values in the look-up table for this zone will remain constant with time. This is equivalent to assuming that the salts emanating from zones 1 and 2 have been completely removed by the geomedia or diluted to insignificant levels when compared to natural groundwater by the time the solution reaches zone 5 . This is equivalent to assuming that the groundwater flow is sufficiently large that it will dilute the leachate to 
the point that no competitive effects exist from the waste form and barrier's leachates. The $\mathrm{K}_{\mathrm{d}}$ values in zone 5 can be considered to be time invariant in our conceptual model. 


\subsection{Summary Tables}

Geochemical input values for the five zones identified in Table 1 and Figure 2 are presented in Tables 2 through 6 . For zones 1 and 2, solubility constraints are provided for some contaminants where appropriate. If the near-field solution concentration of a contaminant is above the "solubility limit," the solubility value will be used to control the solution concentration; if the solution concentration is below this value, then the $K_{d}$ values will be used in the retardation factor equation to calculate solution concentrations. Four $\mathrm{K}_{\mathrm{d}}$ values are provided in each table cell: a reasonable conservative $\mathrm{K}_{\mathrm{d}}$, a "best" estimate (or most probable) $\mathrm{K}_{\mathrm{d}}$, and upper and lower $\mathrm{K}_{\mathrm{d}}$ limits. The reasonable conservative $\mathrm{K}_{d}$ is a reasonable lower-bounding value that takes into consideration potential conditions that may enhance radionuclide migration. This estimate was usually identical to the lower value of the range. For a few situations, the lower limit was not selected as the reasonable conservative $\mathrm{K}_{d}$ value because the lower limit value originated from a questionable experiment or the experimental conditions used to generate the value would yield a lower value than the conditions of the zone of interest merit. The "best" estimates are presented to provide guidance on what the most likely $\mathrm{K}_{\mathrm{d}}$ value is for a given condition. This was based primarily on some central value of the literature or laboratory $\mathrm{K}_{d}$ values and on expert judgment. The concept of using a central value, the statistics, and the raw data involved in identifying this central value were presented by Kaplan and Serne (1995) for I, Np, Se, Tc, and U. The range is provided to help in uncertainty estimates and sensitivity analyses. The distribution of $K_{d}$ values within this range is assumed to be log-normal.

For the empirical solubility estimates only, reasonable conservative and "best" estimate (or most probable) values are given. No ranges or solubility distributions are given at this time. If the 2001 ILAW PA shows that solubility constraints are important, then some effort will be undertaken to improve the uncertainty/sensitivity calculations during the 2003 ILAW PA. Finally, supporting references for the selection of the various $\mathrm{K}_{\mathrm{d}}$ and solubility values or estimates are provided on the tables. 


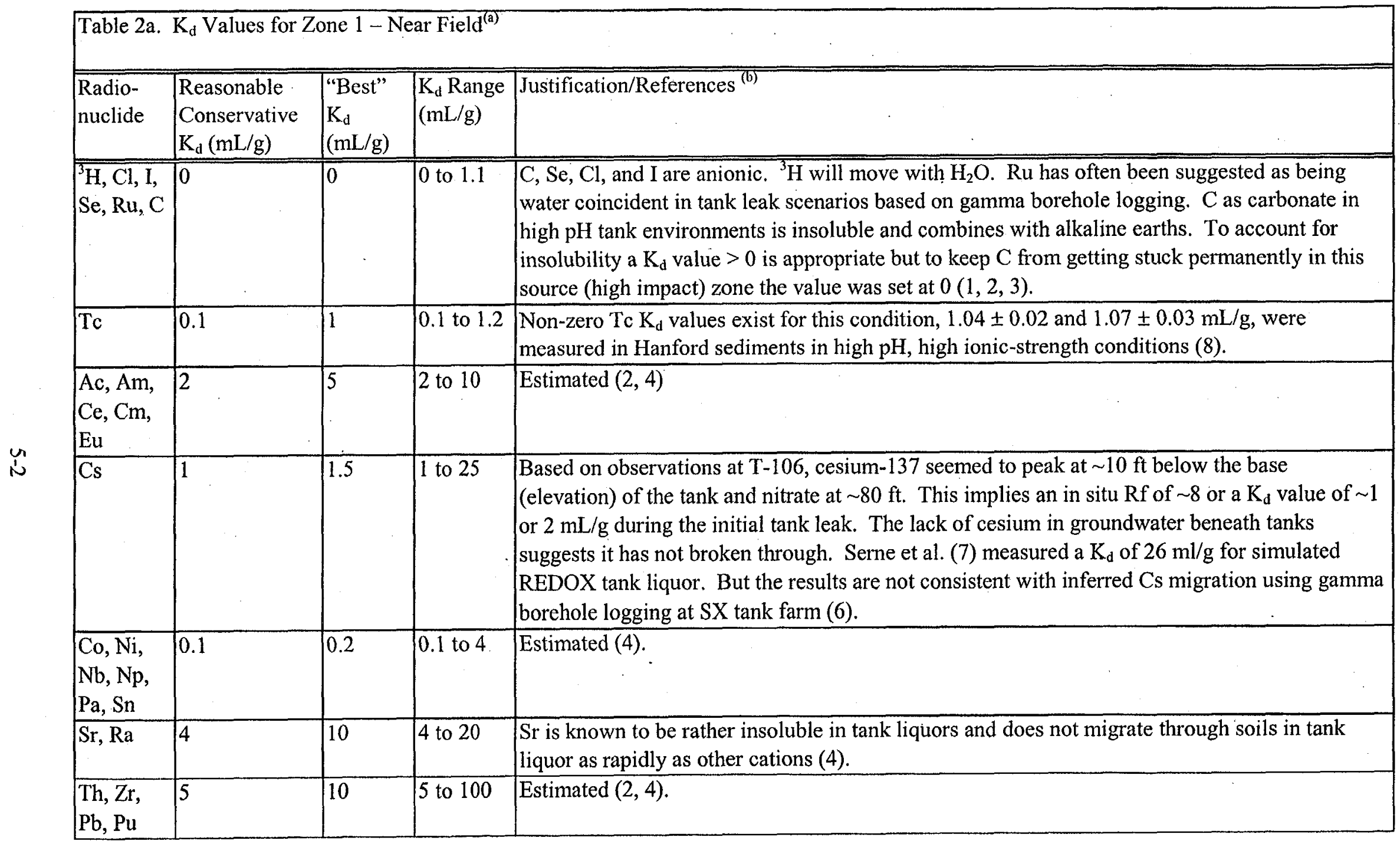




\begin{tabular}{|c|c|c|c|c|}
\hline \multicolumn{5}{|c|}{ Table 2a. (contd) } \\
\hline $\mathrm{U}$ & 5 & 20 & 10 to 800 & $\begin{array}{l}\text { Kaplan et al. (5) reported } \mathrm{U}-\mathrm{K}_{\mathrm{d}} \text { values increased from } \sim 2 \text { to }>500 \mathrm{~mL} / \mathrm{g} \text { when the } \mathrm{pH} \text { of a } \\
\text { Hanford sediment/groundwater slurry increased from } 8.3 \text { to }>10.5 \text {. The extremely high } \mathrm{K}_{\mathrm{d}} \text { was } \\
\text { attributed to } \mathrm{U} \text { (co)precipitation either as uranium phases or as calcite phases. Over a } 1000 \text {-year } \\
\text { period, it is anticipated that the solutions pH of any near field would eventually decrease. Thus, } \\
\text { over time, the } \mathrm{K}_{\mathrm{d}} \text { values would be expected to decrease as the } \mathrm{pH} \text { increased above } \sim 10.5 \text { and the } \\
\text { uranium dissolved from the solid phase. }\end{array}$ \\
\hline \multicolumn{5}{|c|}{$\begin{array}{l}\text { (a) The aqueous phase has a high } \mathrm{pH} \text {, high radionuclide concentrations, and high ionic strength; the solid phase is dominated by backfill, glass, } \\
\text { and glass secondary phases (Table } 1 \text { and Figure } 1 \text { ). No gravel correction to } \mathrm{K}_{\mathrm{d}} \text { values. } \\
\text { (b) References; } 1=\text { Ames and Rai } 1978 ; 2=\text { Thibault et al. } 1990 ; 3=\text { Martin } 1996 ; 4=\text { Ames and Serne } 1991 ; 5=\text { Kaplan et al. } 1998 \mathrm{a} ; 6= \\
\text { Hartman and Dresel } 1997 ; 7=\text { Serne et al. } 1998 ; 8=\text { Kaplan et al. } 1998 \mathrm{~b} \text {. }\end{array}$} \\
\hline
\end{tabular}




\begin{tabular}{|c|c|c|c|}
\hline $\begin{array}{l}\text { Radio- } \\
\text { nuclide }\end{array}$ & $\begin{array}{l}\text { Reasonable } \\
\text { Conservative } \\
\text { Solubility } \\
\text { Limit }(\mathrm{M})\end{array}$ & $\begin{array}{l}\text { "Best" Solubility } \\
\text { Limit (M) }\end{array}$ & Justification/References ${ }^{(6)}$ \\
\hline $\begin{array}{l}{ }^{3} \mathrm{H}, \mathrm{Cl} \\
\mathrm{Tc}, \mathrm{I}, \mathrm{Se} \\
\mathrm{Ru}, \mathrm{C}\end{array}$ & $-\ldots$ & - & $\begin{array}{l}\text { At present, none of these contaminants have solubility constraints in glass leachate. } \mathrm{Tc}, \mathrm{C}, \mathrm{Se}, \mathrm{Cl} \text {, } \\
\text { and I are anionic. }{ }^{3} \mathrm{H} \text { is considered to be present as water. } \mathrm{Ru} \text { may be present as the } \mathrm{RuO}_{4}^{-} \text {. }\end{array}$ \\
\hline $\begin{array}{l}\mathrm{Ac}, \mathrm{Am} \\
\mathrm{Ce}, \mathrm{Cm} \\
\mathrm{Eu}\end{array}$ & $1 \times 10^{-7}$ & $1 \times 10^{-9}$ & $\begin{array}{l}\text { Assume that glass leachate has high } \mathrm{pH} \text { and is similar to concrete leachates. Concrete leachate } \\
\text { solubility values can be realistically applied for hydrous oxide/metal hydroxides being the } \\
\text { controlling solid. Solubility of these types solids are dependent almost solely on pH and nothing } \\
\text { else in the pore fluids }(1,2,3)\end{array}$ \\
\hline $\mathrm{Cs}$ & -- & $\ldots$ & $\begin{array}{l}\text { No solubility constraint is expected. But Cs could be incorporated into the glass weathering } \\
\text { products. Ignoring this should be conservative but not overly so, seeing as adsorption will prevent } \\
\text { Cs from reaching the water table. }\end{array}$ \\
\hline $\mathrm{Co}, \mathrm{Ni}$ & $5 \times 10^{-4}$ & $5 \times 10^{-7}$ & $\begin{array}{l}\text { Assume that metal hydroxide is controlling solid and thus } \mathrm{pH} \text { is the only sensitive variable. There } \\
\text { is data for alkaline cement conditions and we will assume they hold for alkaline glass leachates (1, } \\
2 \text {, and 3). }\end{array}$ \\
\hline $\begin{array}{l}\mathrm{Nb}, \mathrm{Np} \\
\mathrm{Pa}, \mathrm{Sn}\end{array}$ & $5 \times 10^{-4}$ & $5 \times 10^{-6}$ & $\begin{array}{l}\text { Assume that metal hydroxide is the controlling solid. There is empirical data in Ewart et. al.(3) } \\
\text { that predicts much lower than thermodynamic predictions }(1,2,3) \text {. }\end{array}$ \\
\hline $\mathrm{Ra}$ & $1 \times 10^{-5}$ & $3 \times 10^{-6}$ & $\begin{array}{l}\text { Ra sulfate is the controlling solid. Bayless et al. (4) found no precipitation for } \mathrm{Ra} \text { at } 10^{-7} \mathrm{M} \text { in } \\
\text { concrete leachate. }\end{array}$ \\
\hline$\overline{\mathrm{Sr}}$ & $2 \times 10^{-5}$ & $1 \times 10^{-7}$ & $\begin{array}{l}\text { Sr carbonate forms in cements }(1,2,3) \text { but for glass leachates we are not sure. These values may } \\
\text { need to be revised or not used in order to be conservative. }\end{array}$ \\
\hline
\end{tabular}




\begin{tabular}{|c|c|c|c|}
\hline \multicolumn{3}{|c|}{ Table 2b. (contd) } & \multirow{2}{*}{$\begin{array}{l}\text { Assume solubility controlling phase of hydroxide/hydrous oxides for } \mathrm{Th}, \mathrm{Zr} \text {, Pu and } \\
\text { hydroxycarbonates for } \mathrm{Pb} \text {. There is data for Th and } \mathrm{Pu} \text { in cement leachates under oxidizing and } \\
\text { reducing conditions. We chose the oxidizing conditions (3). Other assessments of these values are } \\
\text { presented in }(1,2) \text {. }\end{array}$} \\
\hline $\begin{array}{l}\mathrm{Th}, \mathrm{Zr} \\
\mathrm{Pb}, \mathrm{Pu}\end{array}$ & $5 \times 10^{-7}$ & $1 \times 10^{-8}$ & \\
\hline $\mathrm{U}$ & $1 \times 10^{-6}$ & $1 \times 10^{-7}$ & $\begin{array}{l}\text { Two reports }(1,2) \text { discuss solubility in cements using U(VI) hydrous oxide [schoepite] and } \\
\text { uranophane [calcium } \mathrm{U}(\mathrm{VI}) \text { silicate] as solubility control. Ewart et. al. (3) shows some empirical } \\
\text { data for solubility in cement waters. Kaplan et al. (5) reported } \mathrm{U}-\mathrm{K}_{d} \text { values increased from } \sim 2 \text { to } \\
>500 \mathrm{~mL} / \mathrm{g} \text { when the } \mathrm{pH} \text { of a Hanford sediment/groundwater slurry increased from } 8.3 \text { to }>10.5 \text {. } \\
\text { The extremely high } \mathrm{K}_{\mathrm{d}} \text { was attributed to } \mathrm{U} \text { (co)precipitation either as uranium phases or as calcite } \\
\text { phases. }\end{array}$ \\
\hline \multicolumn{4}{|c|}{$\begin{array}{l}\text { The aqueous phase has a high } \mathrm{pH} \text {, high radionuclide concentrations, and high ionic strength; the solid phase is dominated by backfill, glass, } \\
\text { and glass secondary phases (Table } 1 \text { and Figure 2). No gravel correction to } \mathrm{K}_{\mathrm{d}} \text { values. } \\
\text { (b) References; } 1 \text { = Krupka and Serne (1998); } 2=\text { Brady and Kozak (1995); } 3=\text { Ewart et al. (1992); } 4=\text { Bayliss et al. (1989); } 5=\text { Kaplan et al. } \\
\text { 1998a. }\end{array}$} \\
\hline
\end{tabular}




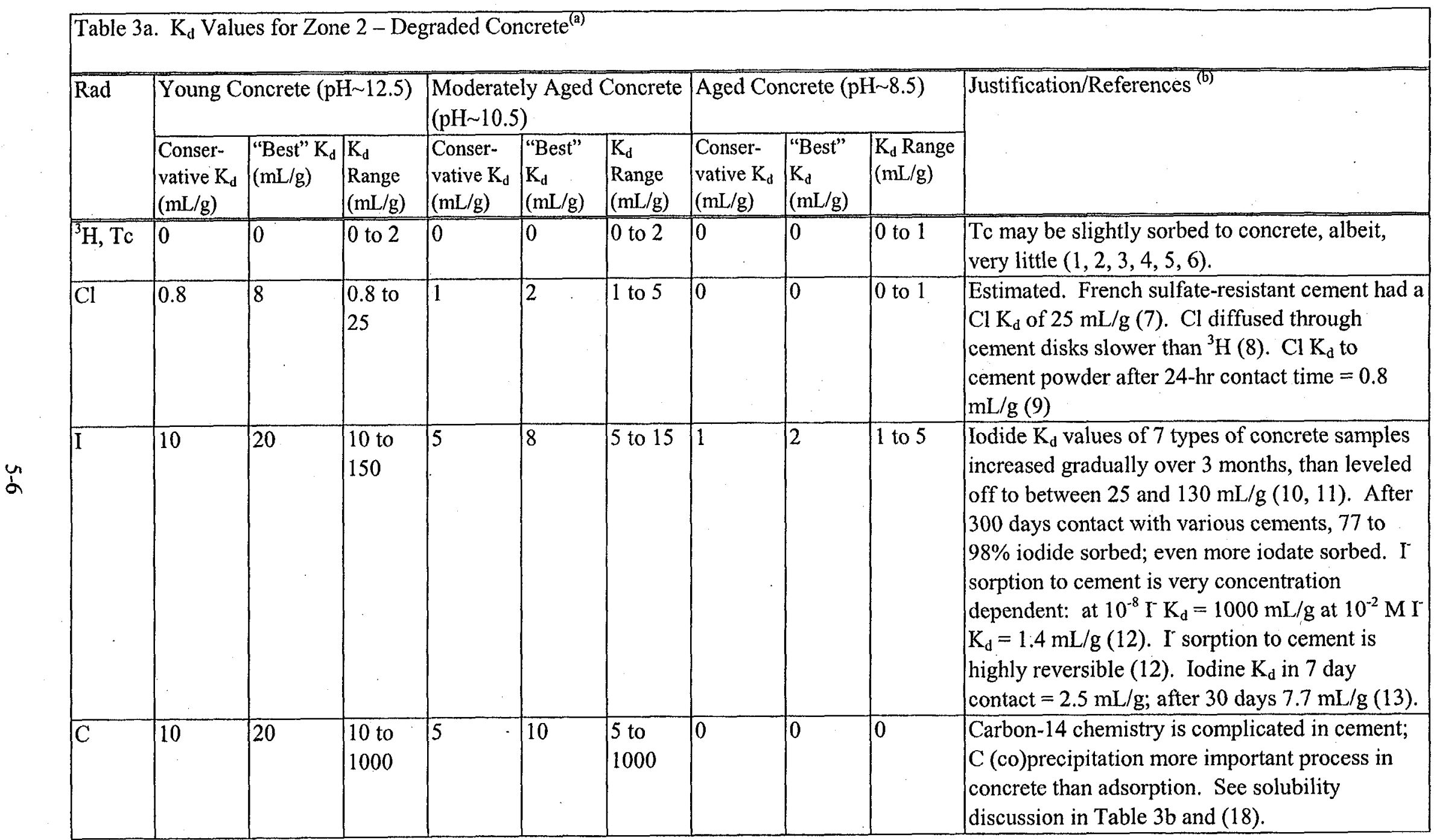




\begin{tabular}{|c|c|c|c|c|c|c|c|c|c|c|}
\hline \multicolumn{11}{|c|}{ Table 3a. (contd) } \\
\hline \begin{tabular}{l|}
$\mathrm{Ac}$, \\
$\mathrm{Am}, \mathrm{Ce}$ \\
$\mathrm{Cm}, \mathrm{Eu}$
\end{tabular} & 2000 & 5000 & $\begin{array}{l}2000 \text { to } \\
40000\end{array}$ & 11000 & 5000 & $\begin{array}{l}1000 \text { to } \\
30000\end{array}$ & 400 & 500 & \begin{tabular}{|l|}
400 to \\
1000
\end{tabular} & $\begin{array}{l}\text { Trivalent metal } \mathrm{K}_{\mathrm{d}} \text { values to concrete exceed } \\
\text { those to sediments }(1) . A m \mathrm{~K}_{\mathrm{d}}>10,000 \mathrm{~mL} / \mathrm{g} \\
\text { (14). Am } \mathrm{K}_{\mathrm{d}} \sim 12,000 \mathrm{~mL} / \mathrm{g} \text { based on diffusion } \\
\text { tests of cement }(15) \text {. Am } \mathrm{K}_{\mathrm{d}} \text { values ranged from } \\
2,500 \text { to } 35,000 \mathrm{~mL} / \mathrm{g} \text { for } 7 \text { different fresh } \\
\text { (unaged)-concrete blends }(10,11) . \text { Am } \mathrm{K}_{d} \text { for } \\
65 \text {-yr old concrete sample }=10,000(10,11) \text {. } \\
\text { Fresh cement Am- } \mathrm{K}_{\mathrm{d}}=2000 \text { for } 24 \text {-hr contact } \\
\text { time (9). Eu- } \mathrm{K}_{\mathrm{d}}=2,400 \mathrm{~mL} / \mathrm{g} \text { for } 24 \mathrm{hr} \text { contact } \\
\text { time (9). }\end{array}$ \\
\hline $\begin{array}{l}\mathrm{Co}, \mathrm{Ni}, \\
\mathrm{Ra}, \mathrm{Sn}\end{array}$ & 70 & 100 & $\begin{array}{l}70 \text { to } \\
250\end{array}$ & 70 & 100 & $\begin{array}{l}70 \text { to } \\
250\end{array}$ & 7 & 10 & 7 to 25 & $\begin{array}{l}\text { Co-K } \mathrm{K}_{\mathrm{d}}=4,300 \mathrm{~mL} / \mathrm{g}(9) \\
\mathrm{Ni-K_{d }} \text { for } 3 \text { cement types: } 500 \text { to } 3000 \mathrm{~mL} / \mathrm{g} \\
(16), 1500 \mathrm{~mL} / \mathrm{g}(9) \text {, and } 500 \text { to } 3000 \mathrm{~mL} / \mathrm{g}(17) .\end{array}$ \\
\hline $\mathrm{Nb}, \mathrm{U}$ & 700 & 1000 & $\begin{array}{l}700 \text { to } \\
2500\end{array}$ & 700 & 1000 & \begin{tabular}{|l}
700 to \\
2500
\end{tabular} & 70 & 100 & \begin{tabular}{|l|}
70 to \\
250
\end{tabular} & $\begin{array}{l}\mathrm{U}(\mathrm{VI})-\mathrm{K}_{\mathrm{d}} \mathrm{S} \text { for } 7 \text { types of cement }=350 \text { to } \\
13,000, \text { average }=\sim 1000 \text { and median }=1400 \\
\mathrm{~mL} / \mathrm{g}(10,11)\end{array}$ \\
\hline$\overline{\mathrm{Cs}}$ & 2 & 3 & 2 to 5 & 20 & 30 & 20 to 50 & 20 & 30 & 20 to 50 & $\begin{array}{l}\text { Cs } \mathrm{K}_{\mathrm{d}} \mathrm{s} \text { in hardened HTS cement discs, } \mathrm{pH} \sim 13.3 \text {, } \\
\text { were } 3 \mathrm{~mL} / \mathrm{g}(7) \text {. Cs } \mathrm{K}_{\mathrm{d}} \mathrm{s} \text { of } 0.2 \mathrm{~mL} / \mathrm{g} \text { were } \\
\text { measured in hardened sulfate resisting cement } \\
(12) \text {. Many authors have reported increase } \\
\text { sorption at } \mathrm{pH} \sim 12.5(13, \text { reviewed by } 23) \text {. }\end{array}$ \\
\hline$\overline{\mathrm{Np}, \mathrm{Pa}}$ & 1400 & 2000 & \begin{tabular}{|l}
1400 to \\
10000
\end{tabular} & 1400 & 2000 & \begin{tabular}{l|}
1400 to \\
10000
\end{tabular} & 140 & 200 & $\begin{array}{l}140 \text { to } \\
500\end{array}$ & $\begin{array}{l}\text { The dominant protactinium species is assumed } \\
\text { to be } \mathrm{Pa} \mathrm{O}_{2}{ }^{+} . \mathrm{NpO}_{2}{ }^{+} \text {is assumed to be a } \\
\text { reasonable analog }(19) \text {. Np sorption test to } 7 \\
\text { different } 65 \text {-yr old cements using cement pore- } \\
\text { water reached steady state after } 30 \text { days, } \mathrm{K}_{\mathrm{d}} \mathrm{S} \\
\text { ranged } 1500 \text { to } 9500 \mathrm{~mL} / \mathrm{g}(10,11) \text {. }\end{array}$ \\
\hline
\end{tabular}




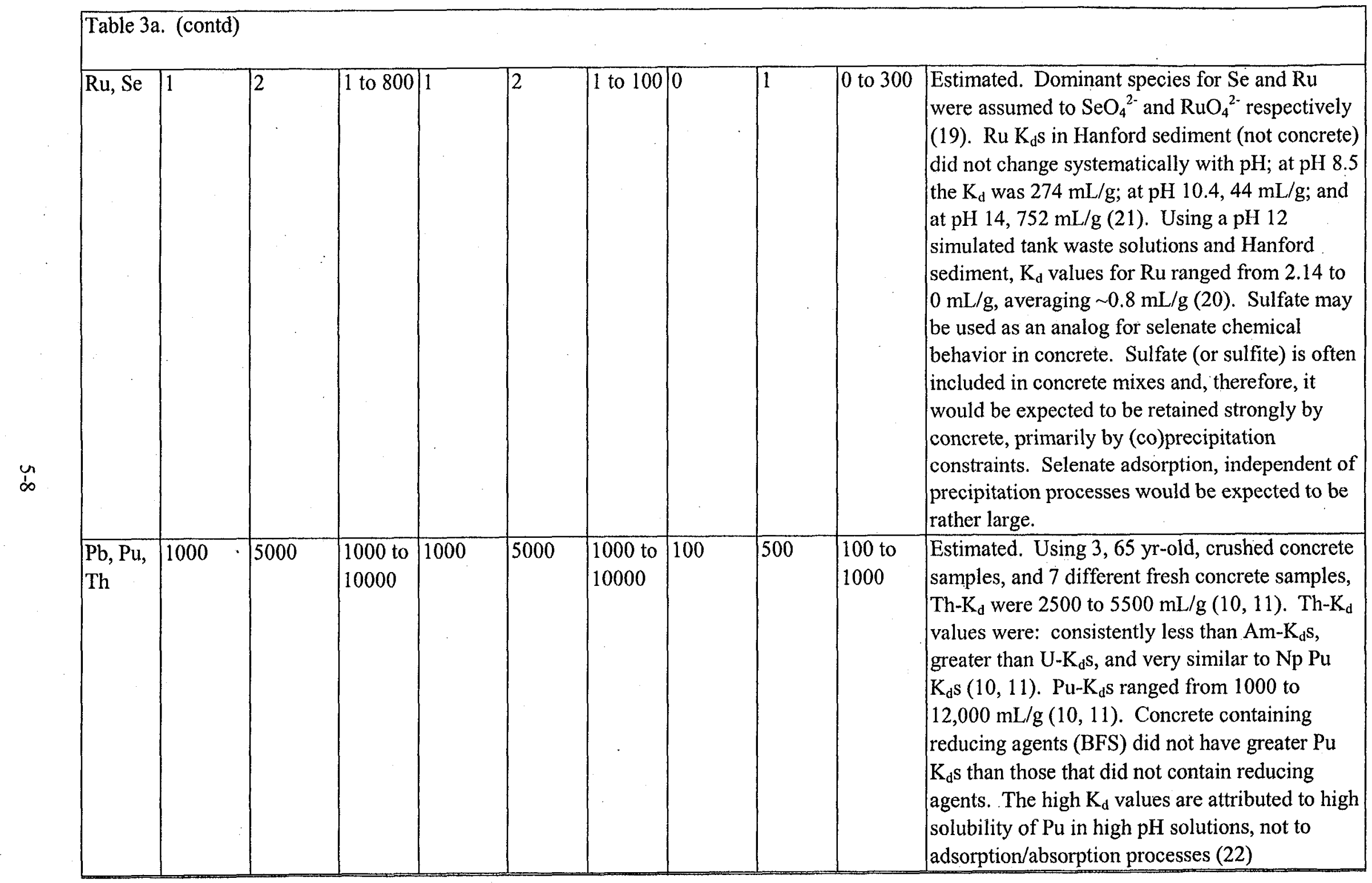


Table 3a. (contd)

(a) The aqueous and solid phases in this zone are greatly influenced by the presence of concrete. The concrete is assumed to age and form three distinct environment (Krupka and Serne 1998).

(b) References: $1=$ Angus and Glasser 1985;2 = Gilliam et al. 1989; $3=$ Tallent et al. 1988; $4=$ Brodda 1988; $5=$ Serne 1990; $6=$ Serne et al. 1992; $7=$ Sarott et al. 1992; $8=$ Johnston and Wilmot 1992; $9=$ Kato and Yanase 1993; $10=$ Allard et al 1984;11 $=$ Hoglund et al. $1985 ; 12=$ Atkinson and Nickerson 1988; $13=$ Hietanen et al. 1985; $14=$ Ewart et al 1988; $15=$ Bayliss et al. $1991 ; 16=$ Hietanen et al. $1984 ; 17=$

Pilkington and Stone 1990; $18=$ Allard et al. 1981; $19=$ Pourbaix 1966;20 = Ames and Rai 1978; $21=$ Rhodes 1957a,b; 22 = Krupka and Serne $1998 ; 23=$ Bradbury and Sarott 1995 . 


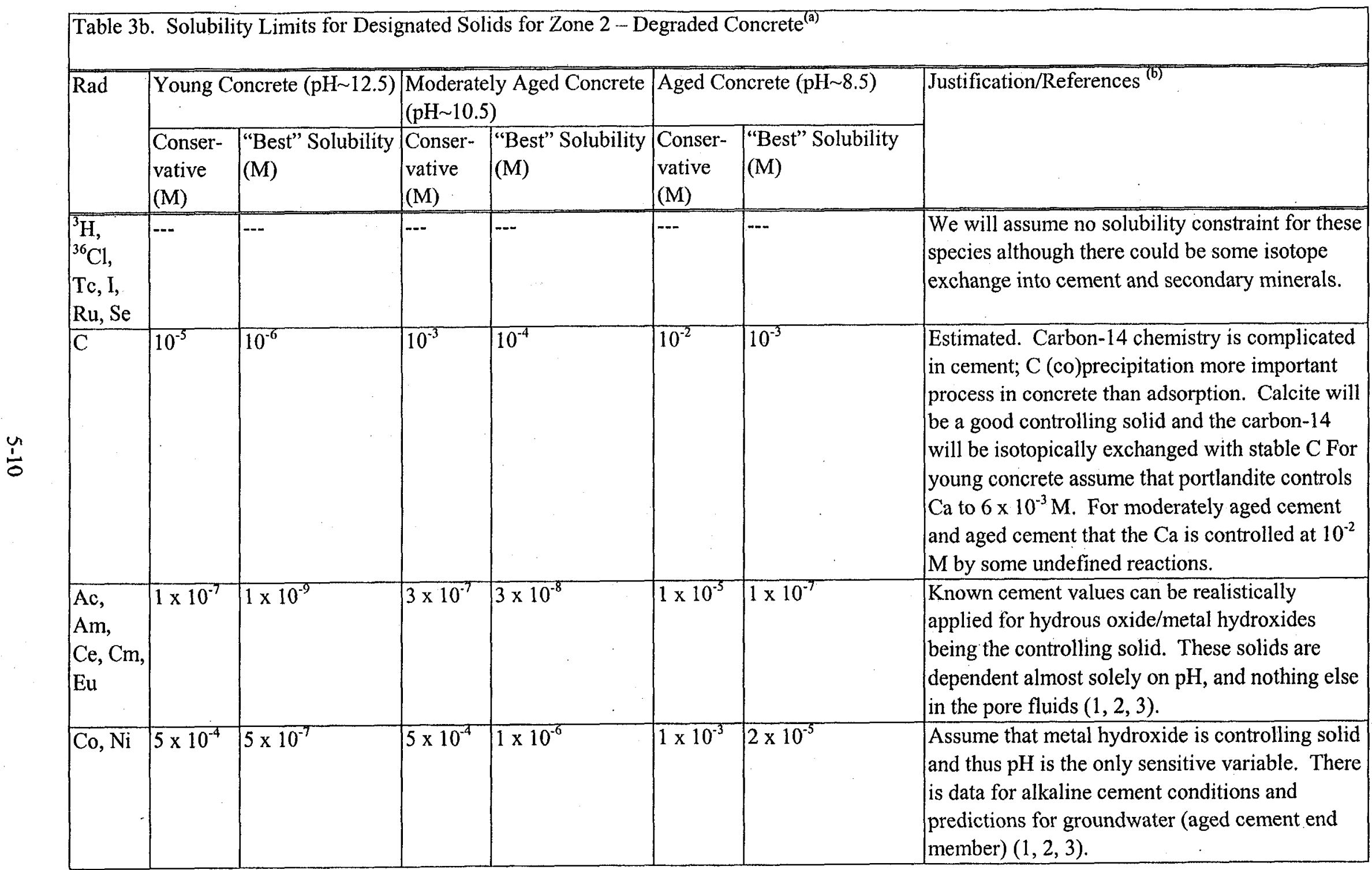




\begin{tabular}{|c|c|c|c|c|c|c|c|}
\hline \multicolumn{8}{|c|}{ Table 3b. (contd) } \\
\hline \multirow[t]{2}{*}{$\overline{\operatorname{Rad}}$} & \multicolumn{2}{|c|}{ Young Concrete ( $\mathrm{pH} \sim 12.5)$} & \multicolumn{2}{|c|}{\begin{tabular}{|l|}
$\begin{array}{l}\text { Moderately Aged Concrete } \\
(\mathrm{pH} \sim 10.5)\end{array}$ \\
\end{tabular}} & \multicolumn{2}{|c|}{ Aged Concrete $(\mathrm{pH} \sim 8.5)$} & \multirow[t]{2}{*}{ Justification/References ${ }^{(\mathfrak{b})}$} \\
\hline & $\begin{array}{l}\text { Conser- } \\
\text { vative } \\
\text { (M) } \\
\end{array}$ & $\begin{array}{l}\text { "Best" Solubility } \\
\text { (M) }\end{array}$ & $\begin{array}{l}\text { Conser- } \\
\text { vative } \\
\text { (M) }\end{array}$ & $\begin{array}{l}\text { "Best" Solubility } \\
(\mathrm{M})\end{array}$ & $\begin{array}{l}\text { Conser- } \\
\text { vative } \\
(\mathrm{M})\end{array}$ & $\begin{array}{l}\text { "Best" Solubility } \\
\text { (M) }\end{array}$ & \\
\hline $\begin{array}{l}\mathrm{Nb}, \mathrm{Np} \\
\mathrm{Pa}, \mathrm{Sn}\end{array}$ & $5 \times 10^{-4}$ & $5 \times 10^{-6}$ & $1 \times 10^{-3}$ & $5 \times 10^{-4}$ & $1 \times 10^{-3}$ & $5 \times 10^{-4}$ & $\begin{array}{l}\text { Assume that metal hydroxide is the controlling } \\
\text { solid. There is empirical data in Ewart et al. (3) } \\
\text { that predicts much lower than thermodynamic } \\
\text { predictions }(1,2,3) \text {. }\end{array}$ \\
\hline $\mathrm{Cs}$ & $-\ldots$ & -.. & $-\ldots$ & --. & $\ldots$ & -..- & No solubility constraint is expected. \\
\hline $\mathrm{Ra}$ & $1 \times 10^{-5}$ & $3 \times 10^{-6}$ & $1 \times 10^{-5}$ & $3 \times 10^{-6}$ & $1 \times 10^{-5}$ & $3 \times 10^{-6}$ & $\begin{array}{l}\text { Ra sulfate is the controlling solid. Bayless et al. } \\
\text { (4) found no precipitation for } \mathrm{Ra} \text { at } 10^{-7} \mathrm{M} \text { in } \\
\text { concrete leachate. }\end{array}$ \\
\hline $\mathrm{Sr}$ & $2 \times 10^{-5}$ & $1 \times 10^{-7}$ & $2 \times 10^{-4}$ & $1 \times 10^{-6}$ & $5 \times 10^{-3}$ & $1 \times 10^{-3}$ & $\begin{array}{l}\text { Sr carbonate forms in cements }(1,2,3) \text { and could } \\
\text { be a plausible control in sediments also. }\end{array}$ \\
\hline $\begin{array}{l}\mathrm{Pb}, \mathrm{Pu} \\
\mathrm{Th}, \mathrm{Zr}\end{array}$ & $5 \times 10^{-7}$ & $1 \times 10^{-8}$ & $5 \times 10^{-7}$ & $1 \times 10^{-8}$ & $5 \times 10^{-6}$ & $1 \times 10^{-7}$ & $\begin{array}{l}\text { Assume hydroxide/hydrous oxides for } \mathrm{Th}, \mathrm{Zr} \\
\mathrm{Pu} \text { and hydroxycarbonates for } \mathrm{Pb} \text {. There is data } \\
\text { for Th and } \mathrm{Pu} \text { in cement leachates under } \\
\text { oxidizing and reducing conditions. We chose } \\
\text { the oxidizing conditions (3). Other assessments } \\
\text { of } \mathrm{Pb}, \mathrm{Pu}, \mathrm{Th} \text {, and/or } \mathrm{Zr} \text { solubility under these } \\
\text { conditions have been conducted }(1,2) \text {. }\end{array}$ \\
\hline
\end{tabular}




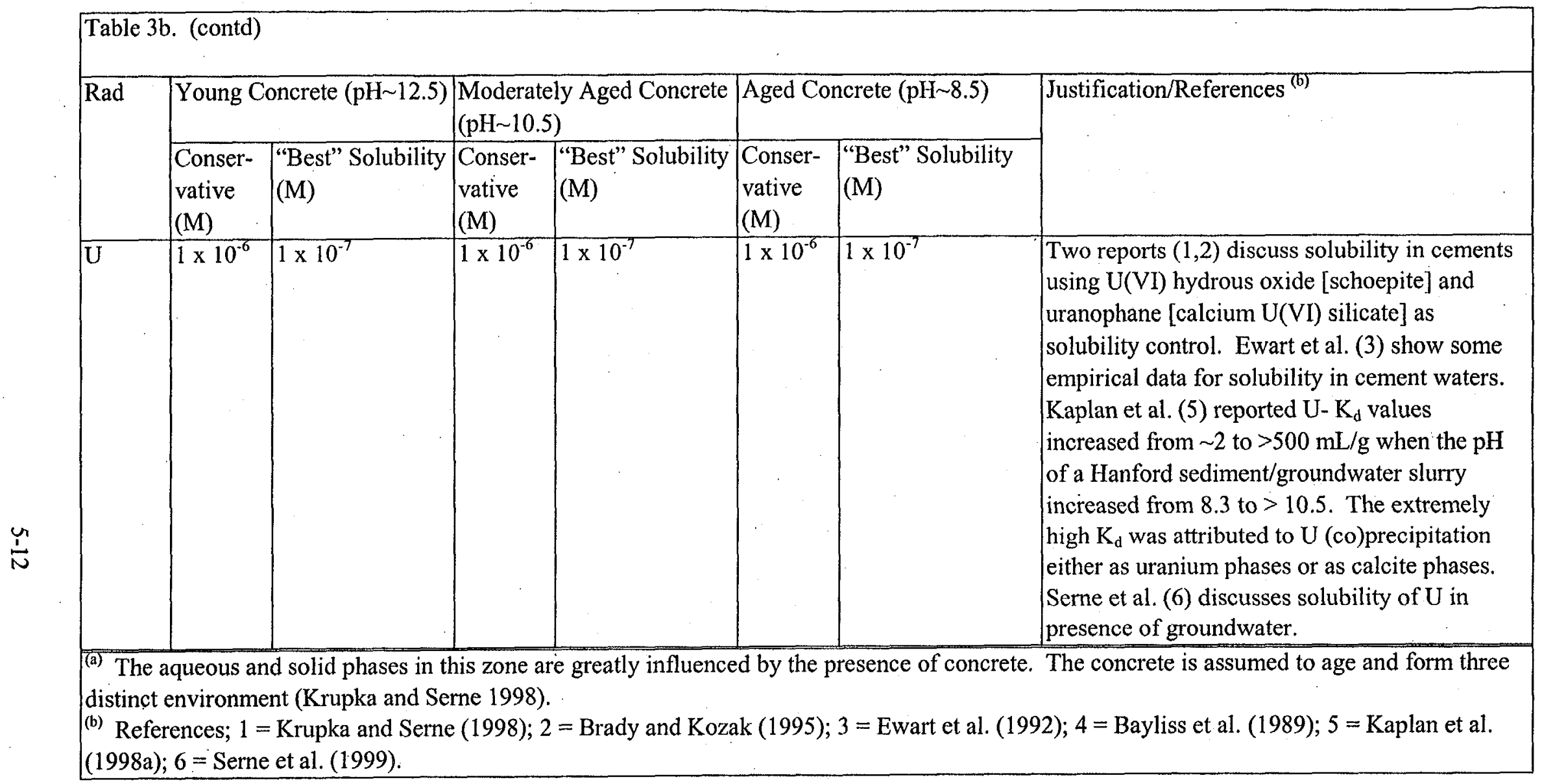




\begin{tabular}{|c|c|c|c|c|}
\hline $\begin{array}{l}\text { Radio- } \\
\text { nuclide }\end{array}$ & $\begin{array}{l}\text { Reasonable } \\
\text { Conservative } \\
\mathrm{K}_{\mathrm{d}}(\mathrm{mL} / \mathrm{g}) \\
\end{array}$ & $\begin{array}{l}" B e s t " \\
\mathrm{~K}_{\mathrm{d}} \\
(\mathrm{mL} / \mathrm{g}) \\
\end{array}$ & $\begin{array}{l}\begin{array}{l}\mathrm{K}_{\mathrm{d}} \text { Range } \\
(\mathrm{mL} / \mathrm{g})\end{array} \\
\end{array}$ & Justification/References ${ }^{\left({ }^{(b)}\right.}$ \\
\hline${ }^{3} \mathrm{H}, \mathrm{Cl}, \mathrm{Tc}$ & $\overline{10}$ & 10 & 0 to 0.1 & Tc and $\mathrm{Cl}$ are anionic. ${ }^{3} \mathrm{H}$ will move with $\mathrm{H}_{2} \mathrm{O}$. \\
\hline $\begin{array}{l}\mathrm{Ac}, \mathrm{Am} \\
\mathrm{Ce}, \mathrm{Cm} \\
\mathrm{Eu}\end{array}$ & 100 & 350 & $\begin{array}{l}100 \text { to } \\
1500\end{array}$ & $\begin{array}{l}\text { Am- } \mathrm{K}_{\mathrm{d}} \mathrm{S}: \text { In low-ionic-strength } \mathrm{Ca} \text { system, }>1200 \mathrm{~mL} / \mathrm{g} \text {; in low-ionic-strength Na system, } 280 \\
\mathrm{~mL} / \mathrm{g}(1)\end{array}$ \\
\hline $\bar{C}$ & 5 & 20 & 5 to 50 & $\begin{array}{l}\text { Estimated. }{ }^{14} \mathrm{C} \text { geochemistry complex and poorly described by } \mathrm{K}_{\mathrm{d}} \text { construct. }{ }^{14} \mathrm{C} \text { is expected to } \\
\text { enter liquid, solid and gas phase through volatilization }\left(\mathrm{CO}_{2} \text {-gas), precipitation with calcite, }\right. \\
\text { isotopic exchange, and adsorption. Based on Martin }(9) \text {, who measured }{ }^{14} \mathrm{C}-\mathrm{K}_{\mathrm{d}} \text { values in } \\
\text { Hanford sediments using uncontaminated Hanford groundwater (relatively low ionic strength). } \\
{ }^{14} \mathrm{C} \text { as } \mathrm{H}^{14} \mathrm{CO}_{3} \mathrm{~K}_{\mathrm{d}} \text { values increased during a } 70 \text { day contact time from } 0(1-\mathrm{hr} \text { contact time) to } \\
400 \mathrm{~mL} / \mathrm{g} \text { in sediment and } 20 \text { (1-hr contact time) to } 360 \mathrm{~mL} / \mathrm{g} \text { in calcrete. }{ }^{14} \mathrm{C} \text { removed by solid } \\
\text { phases never stabilized during } 70 \text { days, suggesting (co)precipitation reaction. }\end{array}$ \\
\hline $\mathrm{Co}$ & 150 & 300 & $\begin{array}{l}150 \text { to } \\
2000\end{array}$ & $\begin{array}{l}\text { In } 0.01 \text { to } 1 \mathrm{M} \mathrm{Na} \text { system, } \mathrm{K}_{\mathrm{d}} \text { is } 1060 \text { to } 4760 \mathrm{~mL} / \mathrm{g}(2) \\
\text { In } 0.01 \text { to } 1 \mathrm{M} \mathrm{Ca} \text { system, } \mathrm{K}_{\mathrm{d}} \text { is } 222 \text { to } 640 \mathrm{~mL} / \mathrm{g}(2) \\
\text { Forms complexes, especially with organics. }\end{array}$ \\
\hline Cs & 40 & 80 & 40 to 2000 & $\begin{array}{l}\text { Estimated. In low-ionic-strength } \mathrm{Na} \text { system, } \mathrm{K}_{\mathrm{d}} \text { is } 64 \text { to } 1170 \mathrm{~mL} / \mathrm{g}(2) \text {. No complexes. } \\
\text { In low-ionic-strength Ca system, } \mathrm{K}_{\mathrm{d}} \text { is } 790 \text { to } 1360 \mathrm{~mL} / \mathrm{g}(2) \text {. } \\
\text { Unpublished recent results from } \mathrm{Zachara}(\mathrm{PNNL}, \mathrm{EMSP} \text { project) using Hanford sediments and } \\
\text { simulated tank waste indicate that Cs sorption decreases markedly compared to when ionic } \\
\text { strength is appreciably lower. }\end{array}$ \\
\hline I & 0 & 0 & 0 to 2 & Anion. Estimated. \\
\hline $\begin{array}{l}\mathrm{Ni}, \mathrm{Sn}, \\
\mathrm{Nb}\end{array}$ & 40 & 80 & 40 to 400 & $\begin{array}{l}\text { Ni is similar to Co but adsorbs slightly less possibly because of moderate complexing. } \\
\text { Estimated }(3,4)\end{array}$ \\
\hline
\end{tabular}




\begin{tabular}{|c|c|c|c|c|}
\hline \multicolumn{5}{|c|}{ Table 4. (contd) } \\
\hline $\mathrm{Np}, \mathrm{Pa}$ & 0.2 & 0.8 & 0.2 to 5 & $\begin{array}{l}\mathrm{Np} \mathrm{K}_{\mathrm{d}} \mathrm{s} \text { in low-ionic-strength solutions }=0.4 \text { to } 4 \mathrm{~mL} / \mathrm{g}(1) \text {. The dominant protactinium species } \\
\text { is assumed to be } \mathrm{PaO}_{2}{ }^{+} . \mathrm{NpO}_{2}{ }^{+} \text {is assumed to be a reasonable analog (10). Based on studies } \\
\text { conducted at the Whiteshell Laboratories (personal communications with } \mathrm{T} \text {. T. (Chuck) } \\
\text { Vandergraaf, Atomic Energy of Canada Limited, Pinawa, Manitoba, Canada), Pa sorbs } \\
\text { appreciably more than } \mathrm{Np} \text {. Thus, } \mathrm{Pa}-\mathrm{K}_{\mathrm{d}} \text { estimates based on measured } \mathrm{Np}-\mathrm{K}_{\mathrm{d}} \text { values will be } \\
\text { conservative. }\end{array}$ \\
\hline $\mathrm{Pb}$ & 20 & 100 & $20-1000$ & Good absorber, insoluble. Estimated (4). \\
\hline $\mathrm{Pu}$ & 80 & 200 & 80 to 1000 & $\mathrm{~K}_{\mathrm{d}}$ is $>98 \mathrm{~mL} / \mathrm{g}(5)$ \\
\hline $\mathrm{Ra}, \mathrm{Sr}$ & 0.2 & 10 & 0.2 to 50 & 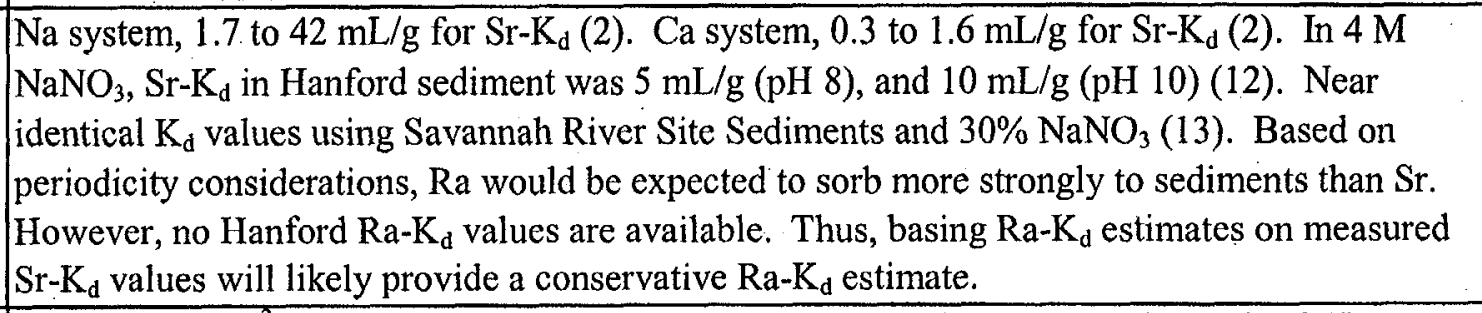 \\
\hline $\mathrm{Ru}$ & 0 & 1 & 0 to 500 & May form $\mathrm{RuO}_{4}{ }^{2-}$ and/or anionic complexes with nitrates and nitrites. Estimate $(3,6,7)$. \\
\hline $\mathrm{Se}$ & 2 & 4 & 2 to 10 & $\begin{array}{l}\text { Anionic. Se } \mathrm{K}_{\mathrm{d}} \text { measured at the ILAW disposal site had } \mathrm{K}_{\mathrm{d}} \text { values of } 6.7 \pm 0.4 \mathrm{~mL} / \mathrm{g}(14) \text {. } \\
\text { Unpublished results of a Se sorption experiment to Hanford sediments in high ionic strength } \\
\left(\mathrm{NaOH} \text { and } \mathrm{NaOCl}_{4}\right) \text { indicate } \mathrm{Se}_{\mathrm{d}} \text { values of } \sim 4 \mathrm{~mL} / \mathrm{g} \text {. }\end{array}$ \\
\hline $\mathrm{Th}, \mathrm{Zr}$ & 40 & 300 & 40 to 500 & Sandy soil data, $\mathrm{K}_{\mathrm{d}}$ is 40 to $470 \mathrm{~mL} / \mathrm{g}$ for $\mathrm{Th}(8)$ \\
\hline $\bar{U}$ & 2 & 10 & 2 to 500 & $\begin{array}{l}\text { Anionic and neutral carbonate and hydroxide species. Kaplan et al. (11) reported } \mathrm{U}-\mathrm{K}_{\mathrm{d}} \text { values } \\
\text { increased from } \sim 2 \text { to }>500 \mathrm{~mL} / \mathrm{g} \text { when the } \mathrm{pH} \text { of a Hanford sediment/groundwater slurry } \\
\text { increased from } 8.3 \text { to }>10.5 \text {. The extremely high } \mathrm{K}_{\mathrm{d}} \text { was attributed to } \mathrm{U} \text { (co)precipitation either } \\
\text { as uranium phases or as calcite phases. }\end{array}$ \\
\hline
\end{tabular}

(a) The aqueous phase is moderately altered from the cement and glass leachate emanating from zones 1 and 2; pH is between 8 (background) and 11 , and the ionic strength is between 0.01 (background) and 0.1 . The solid phase is in the sand-dominated sequence and is slightly altered due to contact with the moderately caustic aqueous phase (Table 1 and Figure 2).

(b) References: $1=$ Routson et al. 1976; $2=$ Routson et al. 1978; $3=$ Ames and Serne 1991; $4=$ Kaplan et al. 1995; $5=$ Rhodes 1957a, b; $6=$ Ames and Rai 1978; $7=$ Barney 1978; $8=$ Sheppard et al. 1976; $9=$ Martin 1996; $10=$ Pourbaix 1966;11 = Kaplan et al. $1998 \mathrm{a} ; 12=$ Rhodes and Nelson 1957;13 = Prout 1959;14 = Kaplan et al. 1998c. 


\begin{tabular}{|c|c|c|c|c|}
\hline $\begin{array}{l}\text { Radio- } \\
\text { nuclide }\end{array}$ & $\begin{array}{l}\text { Reasonable } \\
\text { Conservative } \\
\mathrm{K}_{\mathrm{dgc}}(\mathrm{mL} / \mathrm{g})\end{array}$ & $\begin{array}{l}" B e s t " \\
\mathrm{~K}_{\mathrm{dgc}} \\
(\mathrm{mL} / \mathrm{g})\end{array}$ & $\begin{array}{l}\mathrm{K}_{\mathrm{dgc}} \\
\text { Range } \\
(\mathrm{mL} / \mathrm{g}) \\
\end{array}$ & Justification/References ${ }^{\left({ }^{(1)}\right.}$ \\
\hline$\sqrt{{ }^{3} \mathrm{H}, \mathrm{Cl}, \mathrm{Tc}}$ & 10 & 10 & 0 to 0.01 & No gravel-corrected $\mathrm{K}_{\mathrm{d}}$ data available. $\mathrm{Tc}$ and $\mathrm{Cl}$ are anionic. ${ }^{3} \mathrm{H}$ will move with $\mathrm{H}_{2} \mathrm{O}$. \\
\hline $\begin{array}{l}\mathrm{Ac}, \mathrm{Am}, \\
\mathrm{Ce}, \mathrm{Cm}, \\
\mathrm{Eu}\end{array}$ & 10 & 35 & 10 to 150 & $\begin{array}{l}\text { No gravel-corrected } K_{d} \text { data available. Am-K } \mathrm{K}_{\mathrm{d}} \mathrm{S}: \text { In low-ionic-strength Ca system, }>1200 \mathrm{~mL} / \mathrm{g} \text {; } \\
\text { in low-ionic-strength Na system, } 280 \mathrm{~mL} / \mathrm{g}(1)\end{array}$ \\
\hline$\overline{\mathrm{C}}$ & 0.5 & 2 & 0.5 to 5 & $\begin{array}{l}\text { Estimated. No gravel-corrected } \mathrm{K}_{\mathrm{d}} \text { data available. }{ }^{14} \mathrm{C} \text { geochemistry complex and poorly } \\
\text { described by } \mathrm{K}_{\mathrm{d}} \text { construct. }{ }^{14} \mathrm{C} \text { is expect to enter liquid, solid and gas phase through } \\
\text { volatilization }\left(\mathrm{CO}_{2} \text {-gas), precipitation with calcite, isotopic exchange, and adsorption. Based on }\right. \\
\text { Martin }(9) \text {, who measured }{ }^{14} \mathrm{C}-\mathrm{K}_{\mathrm{d}} \text { values in Hanford sediments using uncontaminated Hanford } \\
\text { groundwater (relatively low ionic strength). } \mathrm{K}_{\mathrm{d}} \text { values increased during a } 70 \text { day contact time } \\
\text { from } 0(1 \text {-hr contact time) to } 400 \mathrm{~mL} / \mathrm{g} \text { in sediment and } 20 \text { (1-hr contact time) to } 360 \mathrm{~mL} / \mathrm{g} \text { in } \\
\text { calcrete. }{ }^{14} \mathrm{C} \text { removed by solid phases never stabilized during } 70 \text { days, suggesting } \\
\text { (co)precipitation reaction. }\end{array}$ \\
\hline Co & 15 & 30 & 15 to 200 & $\begin{array}{l}\text { No gravel-corrected } \mathrm{K}_{\mathrm{d}} \text { data available. } \\
\text { In low-ionic-strength } \mathrm{Na} \text { system, } 1060 \text { to } 4760 \mathrm{~mL} / \mathrm{g}(2) \\
\text { In low-ionic-strength Ca system, } 222 \text { to } 640 \mathrm{~mL} / \mathrm{g}(2) \\
\text { Forms complexes, especially with organics. }\end{array}$ \\
\hline $\mathrm{Cs}$ & 4 & 8 & 4 to 200 & $\begin{array}{l}\text { No gravel-corrected } \mathrm{K}_{\mathrm{d}} \text { data available. No complexes. } \\
\text { Estimated. In } 0.01 \text { to } 0.1 \mathrm{M} \text { Na system, } 64 \text { to } 1170 \mathrm{~mL} / \mathrm{g}(2) \text {. } \\
\text { In } 0.01 \text { to } 0.1 \mathrm{M} \text { Ca system, } 790 \text { to } 1360 \mathrm{~mL} / \mathrm{g}(2) . \\
\text { Unpublished recent results from Zachara (PNNL, EMSP project) using Hanford sediments and } \\
\text { simulated tank waste indicate that Cs sorption decreases markedly compared to when ionic } \\
\text { strength is appreciably lower. }\end{array}$ \\
\hline I & 10 & 0 & 0 to 0.2 & No gravel-corrected $\mathrm{K}_{d}$ data available. Anion. Estimated. \\
\hline $\mathrm{Ni}, \mathrm{Sn}, \mathrm{Nb}$ & 4 & 8 & 4 to 40 & $\begin{array}{l}\text { Ni is similar to Co but adsorbs slightly less possibly because of moderate complexing. } \\
\text { Estimated }(3,4)\end{array}$ \\
\hline
\end{tabular}




\begin{tabular}{|c|c|c|c|c|}
\hline \multicolumn{5}{|c|}{ Table 5. (contd) } \\
\hline $\mathrm{Np}, \mathrm{Pa}$ & 0.02 & 0.08 & $\begin{array}{l}0.04 \text { to } \\
0.5\end{array}$ & $\begin{array}{l}\text { No gravel-corrected } \mathrm{K}_{\mathrm{d}} \text { data available. } \mathrm{Np} \mathrm{K}_{\mathrm{d}} \mathrm{S} \text { in low-ionic-strength solutions }=0.4 \text { to } 4 \mathrm{~mL} / \mathrm{g} \\
\text { (1). The dominant protactinium species is assumed to be } \mathrm{PaO}_{2}{ }^{+} . \mathrm{NpO}_{2}{ }^{+} \text {is assumed to be a } \\
\text { reasonable analog (10). Based on studies conducted at the Whiteshell Laboratories (personal } \\
\text { communication with } \mathrm{T} \text {. T. (Chuck) Vandergraaf, Atomic Energy of Canada Limited, Pinawa, } \\
\text { Manitoba, Canada), Pa sorbs appreciably more than Np. Thus, Pa- } \mathrm{K}_{\mathrm{d}} \text { estimates based on } \\
\text { measured Np- } \mathrm{K}_{\mathrm{d}} \text { values will be conservative. }\end{array}$ \\
\hline $\mathrm{Pb}$ & 2 & 10 & 2 to 100 & No gravel-corrected $\mathrm{K}_{\mathrm{d}}$ data available. Good absorber, insoluble. Estimated (4). \\
\hline $\mathrm{Pu}$ & 8 & 20 & 8 to 100 & No gravel-corrected $\mathrm{K}_{\mathrm{d}}$ data available. $>98 \mathrm{~mL} / \mathrm{g}(5)$ \\
\hline $\mathrm{Ra}, \mathrm{Sr}$ & 0.02 & 1 & 0.02 to 5 & 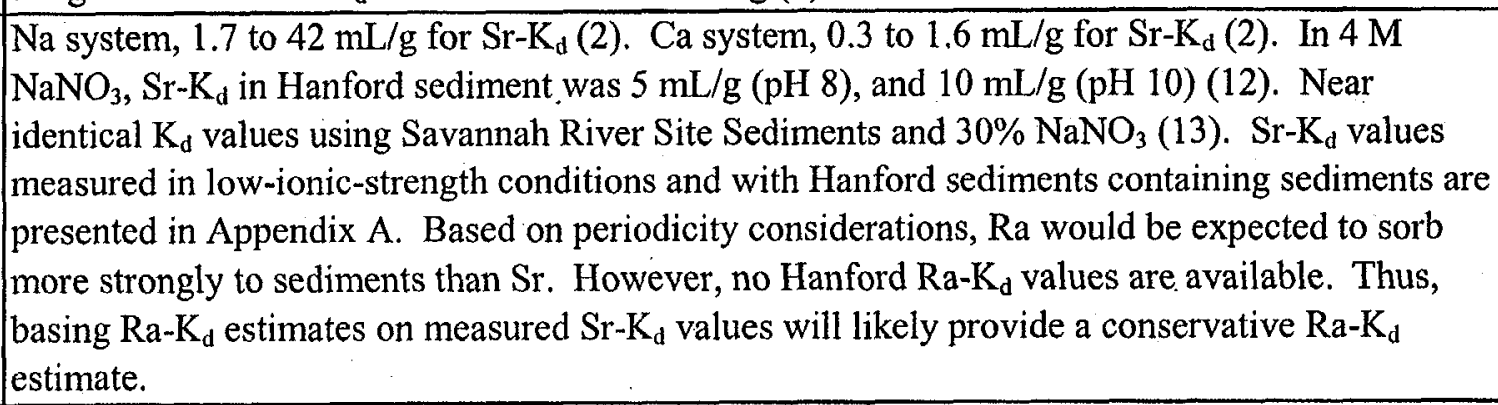 \\
\hline $\mathrm{Ru}$ & 0 & 0.1 & 0 to 50 & $\begin{array}{l}\text { No gravel-corrected } \mathrm{K}_{\mathrm{d}} \text { data available. May form } \mathrm{RuO}_{4}{ }^{2-} \text { and/or anionic complexes with nitrates } \\
\text { and nitrites. Estimate }(3,6,7) \text {. }\end{array}$ \\
\hline $\mathrm{Se}$ & 0.2 & 0.4 & 0.2 to 1 & $\begin{array}{l}\text { No gravel-corrected } \mathrm{K}_{\mathrm{d}} \text { data available. Anionic. Se } \mathrm{K}_{\mathrm{d}} \text { measured at the ILAW disposal site had } \\
\mathrm{K}_{\mathrm{d}} \text { values of } 6.7 \pm 0.4 \mathrm{~mL} / \mathrm{g}(14) \text {. Unpublished results of a Se sorption experiment to Hanford } \\
\text { sediments in high ionic strength ( } \mathrm{NaOH} \text { and } \mathrm{NaOCl}_{4} \text { ) indicate } \mathrm{Se} \mathrm{K}_{\mathrm{d}} \text { values of } \sim 4 \mathrm{~mL} / \mathrm{g} \text {. }\end{array}$ \\
\hline $\mathrm{Th}, \mathrm{Zr}$ & 4 & 30 & 4 to 50 & No gravel-corrected $K_{d}$ data available. Sandy soil data, 40 to $470 \mathrm{~mL} / \mathrm{g}$ for $\mathrm{Th}(8)$. \\
\hline $\mathrm{U}$ & 0.2 & 1 & 0.2 to 50 & $\begin{array}{l}\text { No gravel-corrected } \mathrm{K}_{\mathrm{d}} \text { data available. Anionic and neutral carbonate and hydroxide species. } \\
\text { Kaplan et al. (11) reported } \mathrm{U}-\mathrm{K}_{\mathrm{d}} \text { values increased from } \sim 2 \text { to }>500 \mathrm{~mL} / \mathrm{g} \text { when the } \mathrm{pH} \text { of a } \\
\text { Hanford sediment/groundwater slurry increased from } 8.3 \text { to }>10.5 \text {. The extremely high } \mathrm{K}_{\mathrm{d}} \text { was } \\
\text { attributed to } \mathrm{U} \text { (co)precipitation either as uranium phases or as calcite phases. }\end{array}$ \\
\hline
\end{tabular}


Table 5. (contd)

(a) The aqueous phase is moderately altered from the cement and glass leachate emanating from zones 1 and 2; pH is between 8 (background) and 11 , and the ionic strength is between 0.01 (background) and 0.1 . The solid phase is in the sand-dominated sequence and is slightly altered due to contact with the moderately caustic aqueous phase (Table 1 and Figure 2).

(b) References: $1=$ Routson et al. 1976; $2=$ Routson et al. 1978; $3=$ Ames and Serne 1991; $4=$ Kaplan et al. 1995; $5=$ Rhodes 1957a, b; 6 = Ames and Rai 1978; $7=$ Barney 1978; $8=$ Sheppard et al. 1976; $9=$ Martin 1996; $10=$ Pourbaix 1966; $11=$ Kaplan et al. $1998 \mathrm{a} ; 12=$ Rhodes and Nelson 1957; $13=$ Prout 1959; $14=$ Kaplan et al. 1998c. 


\begin{tabular}{|c|c|c|c|c|}
\hline $\begin{array}{l}\text { Radio- } \\
\text { nuclide }\end{array}$ & $\begin{array}{l}\text { Reasonable } \\
\text { Conservative } \\
\mathrm{K}_{\mathrm{dgc}}(\mathrm{mL} / \mathrm{g}) \\
\end{array}$ & \begin{tabular}{|l|}
$\mathrm{K}_{\mathrm{dgc}}$ \\
$(\mathrm{mL} / \mathrm{g})$
\end{tabular} & $\begin{array}{l}\mathrm{K}_{\mathrm{dgc}} \\
\text { Range } \\
(\mathrm{mL} / \mathrm{g}) \\
\end{array}$ & Justification/References ${ }^{(0)}$ \\
\hline${ }^{3} \mathrm{H}, \mathrm{Cl}, \mathrm{Tc}$ & 0 & 0 & \begin{tabular}{l|}
0 to \\
0.06
\end{tabular} & $\begin{array}{l}\text { No laboratory results of gravel- } \mathrm{K}_{\mathrm{d}} \text { values available. Tc exists predominantly as } \mathrm{TcO}_{4}{ }^{*} \text {. } \\
\text { review of Hanford sediment Tc- } \mathrm{K}_{\mathrm{d}} \text { values showed a range of }-2.8 \text { to } 0.6 \mathrm{~mL} / \mathrm{g} \text { for } 15 \\
\text { observations; median was } 0.1-\mathrm{mL} / \mathrm{g}(1) \text {. Later studies did not change this range but did } \\
\text { decrease the median slightly to }-0.1 \mathrm{~mL} / \mathrm{g}(2) \text {. Negative } \mathrm{K}_{\mathrm{d}} \text { values are possible and may not } \\
\text { be an experimental artifact }(2) .{ }^{3} \mathrm{H} \text { is expected to move along with water. Cl is expected to } \\
\text { behave as a dissolved anionic species. Most recent results using ILAW specific borehole } \\
\text { sediments [299-E17-21] yielded Tc- } \mathrm{K}_{\mathrm{d}} \text { of } 0 \mathrm{~mL} / \mathrm{g}(18) \text {. Gravel correction of negative } \mathrm{K}_{\mathrm{d}} \\
\text { values in Estimated } \mathrm{K}_{\mathrm{d}} \text { Range was assumed to make } \mathrm{K}_{\mathrm{d}} \text { less negative by a factor of } 0.9 \\
\text { because of reduced surface area that would create the anion exclusion. }\end{array}$ \\
\hline $\begin{array}{l}\mathrm{Ac}, \mathrm{Am}, \\
\mathrm{Ce}, \mathrm{Cm}, \\
\mathrm{Eu}\end{array}$ & 6 & 30 & 6 to 130 & $\begin{array}{l}\text { No laboratory results of gravel- } \mathrm{K}_{\mathrm{d}} \text { values available. Am- } \mathrm{K}_{\mathrm{d}}: 67 \text { to }>1200 \mathrm{~mL} / \mathrm{g}(3) . A m-\mathrm{K}_{\mathrm{d}} \text { : } \\
125 \text { to } 833 \mathrm{~mL} / \mathrm{g}(4)\end{array}$ \\
\hline $\mathrm{C}$ & 0.05 & 0.5 & $\begin{array}{l}0.05 \text { to } \\
100\end{array}$ & $\begin{array}{l}\text { No laboratory results of gravel- } \mathrm{K}_{\mathrm{d}} \text { values available. Assumed dominant species: } \mathrm{HCO}_{3} \text {. } \\
\text { Three processes will be acting on the }{ }^{14} \mathrm{C} \text { to take it out of solution: adsorption onto the calcite } \\
\text { surface, volatilization as } \mathrm{CO}_{2} \text { gas, and precipitation into the calcite structure. The latter } \\
\text { process is largely irreversible; therefore, it is not well represented by the } \mathrm{K}_{\mathrm{d}} \text { construct }\left(\mathrm{K}_{\mathrm{d}}\right. \\
\text { assumes that adsorption occurs as readily as desorption). Volatilization is entirely removed } \\
\text { from the definition of the } \mathrm{K}_{\mathrm{d}} \text { construct. In systems that contain higher concentrations of } \\
\text { carbonate minerals, such as the calcrete layer in the } 200 \text { West Area, an appreciably higher } \mathrm{K}_{\mathrm{d}} \\
\text { should be used to account for the isotopic dilution/precipitation reaction that may occur, a } \mathrm{K}_{\mathrm{d}} \\
\text { of } 100 \mathrm{~mL} / \mathrm{g} \text { would be appropriate for such a system. Since most of the } 100 \text { and } 200 \text { plateau } \\
\text { areas contain }<1 \% \text { carbonate, lower } \mathrm{K}_{\mathrm{d}} \text { values are warranted for these areas, such as } 0.5 \mathrm{~mL} / \mathrm{g} \text {. } \\
\mathrm{K}_{\mathrm{d}} \text { values of }{ }^{14} \mathrm{C} \text { of }>250 \mathrm{~mL} / \mathrm{g} \text { have been measured in calcite (5). At } 100 \mathrm{~K} \text { Area, the } \mathrm{C}-14 \text { is } \\
\text { widely distributed down gradient from a major source (crib). Additional references: } 6,7,8 \text {, } \\
9 \text {, and } 10 \text {. Estimated range. }\end{array}$ \\
\hline
\end{tabular}




\begin{tabular}{|c|c|c|c|c|}
\hline$\overline{\mathrm{Co}}$ & 100 & 200 & $\begin{array}{l}100 \text { to } \\
1250\end{array}$ & $\begin{array}{l}\text { No laboratory results of gravel- } \mathrm{K}_{\mathrm{d}} \text { values available. Na system, } 1290 \text { to } 2120 \mathrm{~mL} / \mathrm{g}(11) ; \mathrm{Ca} \\
\text { system, } 2000 \text { to } 3870 \mathrm{~mL} / \mathrm{g}(11) ; \text { Hanford sediment/groundwater system } 11600 \text { to } 12500 \\
\mathrm{~mL} / \mathrm{g}(12)\end{array}$ \\
\hline$\overline{\mathrm{Cs}}$ & 50 & 200 & $\begin{array}{l}50 \text { to } \\
400\end{array}$ & $\begin{array}{l}\text { No laboratory results of gravel- } \mathrm{K}_{\mathrm{d}} \text { values available. } \\
\text { Na system, } 1410 \text { to } 1590 \mathrm{~mL} / \mathrm{g}(11) \\
\text { Hanford sediment/groundwater system, } 540 \text { to } 3180 \mathrm{~mL} / \mathrm{g}(12) \text {. Most recent results using } \\
\text { lLAW specific borehole sediments [299-E17-21] yielded } \mathrm{K}_{\mathrm{d}} \text { of } 2,030 \pm 597(18) \text {. }\end{array}$ \\
\hline I & 0 & 0.01 & 0 to 1.5 & $\begin{array}{l}\text { No laboratory results of gravel-K } \mathrm{K}_{\mathrm{d}} \text { values available. A review of Hanford sediment } \mathrm{I}-\mathrm{K}_{\mathrm{d}} \\
\text { values showed a range of } 0.7 \text { to } 15 \mathrm{~mL} / \mathrm{g} \text { for } 9 \text { observations; median was } 0.7-\mathrm{mL} / \mathrm{g}(1) \text {. Later } \\
\text { studies increased this range to } 0.2 \text { to } 15 \mathrm{~mL} / \mathrm{g} \text {; the median was decreased to } 0.3 \mathrm{~mL} / \mathrm{g}(2) \text {. } \\
\text { Most recent results using ILAW specific borehole sediments [299-E17-21] yielded } \mathrm{K}_{\mathrm{d}} \text { of } 0 \\
\mathrm{~mL} / \mathrm{g} \text {. See Kaplan et al. (18) for details. }\end{array}$ \\
\hline $\begin{array}{l}\mathrm{Ni}, \mathrm{Sn}, \\
\mathrm{Nb}\end{array}$ & 5 & 30 & $\begin{array}{l}5 \text { to } \\
250\end{array}$ & $\begin{array}{l}\text { No laboratory results of gravel- } \mathrm{K}_{\mathrm{d}} \text { values available. } \\
\text { Ni: Hanford sediment/groundwater system, } 440 \text { to } 2350 \mathrm{~mL} / \mathrm{g}(12) \\
\text { Ni: A study of a broad range of sediments, including those from Hanford had Ni- } \mathrm{K}_{d} \mathrm{~s} \text { of } 50 \\
\text { to } 340 \mathrm{~mL} / \mathrm{g}(13) \text {. }\end{array}$ \\
\hline$\overline{\mathrm{Np}, \mathrm{Pa}}$ & \begin{tabular}{|l|}
0.2 \\
\end{tabular} & 1.5 & $\begin{array}{l}0.2 \text { to } \\
2.5\end{array}$ & $\begin{array}{l}\text { No laboratory results of gravel- } \mathrm{K}_{\mathrm{d}} \text { values available. A review of Hanford sediment Np-K} \mathrm{K}_{\mathrm{d}} \\
\text { values showed range of } 2.4 \text { to } 21.7 \mathrm{~mL} / \mathrm{g} \text { for } 4 \text { observations; median was } 17.8 \mathrm{~mL} / \mathrm{g}(1) \text {. } \\
\text { Later studies increased the } \mathrm{K}_{\mathrm{d}} \mathrm{s} \text { to } 2.2 \text { to } 21.7 \mathrm{~mL} / \mathrm{g} \text {; the median of these later studies was } 15 \\
\mathrm{~mL} / \mathrm{g} \text { (2). The dominant protactinium species is assumed to be } \mathrm{PaO}_{2}{ }^{+} \text {and } \mathrm{NpO}_{2}{ }^{+} \text {is assumed } \\
\text { to be a reasonable analog (19). Based on studies conducted at the Whiteshell Laboratories } \\
\text { (personal communications with T. T. (Chuck) Vandergraaf, Atomic Energy of Canada } \\
\text { Limited, Pinawa, Manitoba, Canada), Pa sorbs appreciably more than Np. Thus, Pa- } \mathrm{K}_{\mathrm{d}} \\
\text { estimates based on measured Np- } \mathrm{K}_{\mathrm{d}} \text { values will be conservative. }\end{array}$ \\
\hline$\overline{\mathrm{Pb}}$ & 800 & 1000 & $\begin{array}{l}800 \text { to } \\
8000\end{array}$ & $\begin{array}{l}\text { No laboratory results of gravel- } \mathrm{K}_{\mathrm{d}} \text { values available. } \mathrm{pH} 6 \text { and no competing ions: } 13,000 \text { to } \\
79,000 \mathrm{~mL} / \mathrm{g}(14)\end{array}$ \\
\hline$\overline{\mathrm{Pu}}$ & 5 & 15 & $\begin{array}{l}5 \text { to } \\
200\end{array}$ & $\begin{array}{l}\text { No laboratory results of gravel- } \mathrm{K}_{d} \text { values available. } \mathrm{Pu}(\mathrm{V}, \mathrm{VI}): \mathrm{pH} 4 \text { to } 12: 80 \text { to }>1980 \\
\mathrm{~mL} / \mathrm{g}(17)\end{array}$ \\
\hline$\overline{\mathrm{Ra}, \mathrm{Sr}}$ & 0.5 & \begin{tabular}{|l|}
1.4 \\
\end{tabular} & $\begin{array}{l}0.5 \text { to } \\
20\end{array}$ & $\begin{array}{l}\text { Sr K } \mathrm{K}_{\mathrm{d}} \text { values: Na system, } 173 \mathrm{~mL} / \mathrm{g}, 49 \text { to } 50 \mathrm{~mL} / \mathrm{g}(11), \text { Ca system, } 8 \text { to } 13 \mathrm{~mL} / \mathrm{g}, 5 \text { to } 19 \\
\mathrm{~mL} / \mathrm{g}(11), 5 \text { to } 120 \mathrm{~mL} / \mathrm{g}(15), 19.1 \text { to } 21.5 \mathrm{~mL} / \mathrm{g}(12), \mathrm{Na} \text { system, } \mathrm{pH} 7 \text { to } 11,14.9 \text { to } 25.1 \\
\mathrm{~mL} / \mathrm{g}(16) . \text { Recent data using ILAW borehole sediment [299-E17-21] yielded Sr-K } \mathrm{K}_{\mathrm{d}} \text { values }\end{array}$ \\
\hline
\end{tabular}




\begin{tabular}{|c|c|c|c|c|}
\hline \multicolumn{5}{|c|}{ Table 6. (contd) } \\
\hline & & & & $\begin{array}{l}\text { of } 14.3 \pm 1.6 \mathrm{~mL} / \mathrm{g}(18) \text {. See Appendix A for } S r \mathrm{~K}_{\mathrm{d}} \text { values measured with sediments. } \\
\text { containing gravel. Based on periodicity considerations, Ra would be expected to sorb more } \\
\text { strongly to sediments than Sr. However, no Hanford Ra- } \mathrm{K}_{\mathrm{d}} \text { values are available. Thus, } \\
\text { basing Ra- } \mathrm{K}_{\mathrm{d}} \text { estimates on measured Sr-K } \mathrm{K}_{\mathrm{d}} \text { values will likely provide a conservative Ra- } \mathrm{K}_{\mathrm{d}} \\
\text { estimate. }\end{array}$ \\
\hline $\mathrm{Ru}$ & 1 & 2 & $\begin{array}{l}1 \text { to } \\
100\end{array}$ & No laboratory results of gravel- $\mathrm{K}_{\mathrm{d}}$ values available. Estimated (17 as cited in 11$)$ \\
\hline$\overline{\mathrm{Se}}$ & 0.3 & 0.7 & $\begin{array}{l}0.3 \text { to } \\
1.5\end{array}$ & $\begin{array}{l}\text { No laboratory results of gravel- } \mathrm{K}_{\mathrm{d}} \text { values available. Hanford groundwater/sediment system: } \\
-3.44 \text { to } 0.78 \mathrm{~mL} / \mathrm{g}(12) \text {. Most recent data using ILAW borehole sediment [299-E17-21], } \\
\text { which did not contain measurable amounts of gravel, yielded } \mathrm{K}_{\mathrm{d}} \text { values ranging from } 3.75 \text { to } \\
10.85 \mathrm{~mL} / \mathrm{g} \text { and had an average of } 6.7 \pm 1.9 \mathrm{~mL} / \mathrm{g}(18) \text {. }\end{array}$ \\
\hline $\mathrm{Th}, \mathrm{Zr}$ & 4 & 100 & $\begin{array}{l}4 \text { to } \\
250\end{array}$ & $\begin{array}{l}\text { Estimated. No laboratory results of gravel- } \mathrm{K}_{\mathrm{d}} \text { values available. } \\
\mathrm{Zr}: \mathrm{pH} 6 \text { to } 12: 90 \text { to }>2000 \mathrm{~mL} / \mathrm{g}(15)\end{array}$ \\
\hline$\overline{\mathrm{U}}$ & 0.05 & 0.06 & $\begin{array}{l}0.01 \text { to } \\
8\end{array}$ & $\begin{array}{l}\text { No laboratory results of gravel- } \mathrm{K}_{\mathrm{d}} \text { values available. A review of Hanford sediment } \mathrm{U}-\mathrm{K}_{\mathrm{d}} \\
\text { values showed range of } 0.1 \text { to } 79.3 \mathrm{~mL} / \mathrm{g} \text { for } 13 \text { observations; median was } 0.6 \mathrm{~mL} / \mathrm{g}(1) \text {. } \\
\text { Results from later studies support the range (2). In all reported data, some } \mathrm{U} \text { was adsorbed } \\
\text { by Hanford sediments and }>90 \% \text { of the values were between } 0.6 \text { and } 4 \mathrm{~mL} / \mathrm{g} \text {. Most recent } \\
\text { work with the ILAW Borehole sediment [299-E17-21] yielded } \mathrm{K}_{\mathrm{d}} \text { of } 0.6 \pm 0.1 \text {. See }(18) \text {. }\end{array}$ \\
\hline \multicolumn{5}{|c|}{ 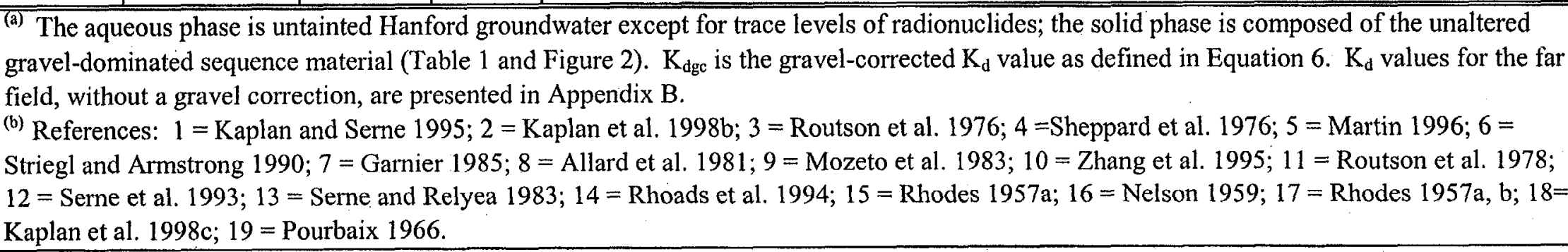 } \\
\hline
\end{tabular}




\subsection{Review Process}

\subsection{Internal Review}

Scientists from Pacific Northwest National Laboratory's (PNNL) Applied Geology and Geochemistry group who were not contributors to the ILAW project performed an internal peer review concurrent with the Hanford Review and to cover the required PNNL/DOE document clearance process. The data package was created in the format of a typical PNNL topical report.

\subsection{Hanford Review}

The Hanford Site personnel who reviewed this data package were the following:

- Fred Mann, Fluor Daniel Northwest, Inc.

- Harry Babad, Westinghouse Hanford Company retired (private consultant)

- Tom E. Jones, MACTEC-Meier.

We have received and addressed the comments of the Internal Hanford Review Team in the September 10,1999 version of this document. The comments were not contentious enough to warrant a comment resolution meeting prior to submittal for review by the other Hanford Site organizations (DOE/Bechtel Hanford, Inc./Lockheed Martin Hanford Corporation).

The September 10, 1999 version of this geochemical data package was then sent concurrently to DOE Richland Operations Office of River Protection, Bechtel Hanford Inc., and Lockheed Martin Hanford Corporation project management for review. Their comments were minor. The data package was revised a second time on September 20,1999. This revision was sent to the external review team.

\subsection{External Review}

We solicited review comments from external reviewers. The members of the external review were:

- Patrick V. Brady, Sandia National Laboratories

- Steve Serkiz, Westinghouse Savannah River Company

- Tjalle T. (Chuck) Vandergraaf, Atomic Energy of Canada, Limited at Pinawa, Manitoba, Canada.

Resumes for these three reviewers are available from R. J. Serne, PNNL. The reviewers were given the data package and instructions on what was expected of them. After they reviewed the instructions and had all questions answered, the review process started in fiscal year 2000. The three sets of review comments were considered, and our responses to the individual questions were shared among all external reviewers. This occurred in mid-December 1999. A final review was performed by Fred Mann prior to submittal to Lockheed Martin Hanford Corporation and DOE on December 20, 1999. Each reviewer prepared comments on the electronic September 20,1999 draft and in e-mails. Our responses to the main comments were prepared, and an electronic file [Respon 2.doc] was circulated. The final draft of the data package, December 20,1999 and the response file will be used by the reviewers to finalize any 
comments. These final comments, the Respon 2.doc electronic file and the data package will become part of the public record associated with this data package.

\subsection{Scope of the Work Reviewed}

The reviewers (both internal and external) were given the data tables of $\mathrm{K}_{\mathrm{d}}$ and solubility controls for each of the five geochemical zones for each contaminant, the reference to the publicly available documents that were used, and the rationale for the choice of each value. The rationale, for those values that were chosen by relying on expert judgment and generic literature, were especially clearly documented. We also prepared a general description of our overarching philosophy on approaching the selection of geochemical parameters for the ILAW PA in Chapter 2.0. In the final version of the data package public record, we will include an assessment of how satisfied we are with the technical defensibility of each selected value and a priority listing on which parameters deserve the attention of future funding. The prioritization will also include a brief discussion of the types of test that would best be performed to improve technical defensibility and what key parameters should be controlled, varied, or monitored in the experimental test program.

\subsection{Review Criteria}

The reviewers were given all the above material and were asked to review/comment on several levels, including the following:

- understandability of the overall geochemical approach from a "layman's" and "systems PA" approach

- technical defensibility of the overall geochemical approach (peer-to-peer technical comments)

- technical opinion on the particular $\mathrm{K}_{\mathrm{d}}$ and solubility constraints provided for each geochemical zone and contaminant

- request for missing/overlooked data that the reviewers think would improve selected values

- opinion on our assessment of satisfaction of the "defensibility" for each value or contaminant's overall geochemical database

- assessment of our choice and prioritization for future work regarding contaminants that need more study and on the type of tests to perform and what are the key parameters to vary, monitor, or control. 


\subsection{Schedule}

\begin{tabular}{|c|c|c|}
\hline & Item & $\overline{\text { Date }}$ \\
\hline 1 & Send data package plan to technical representative for review & March 30, 1999 \\
\hline 2 & Final plan, incorporating comments issued by the tech. rep. & April 30, 1999 \\
\hline 3 & $\begin{array}{l}\text { Inform technical representative by electronic message that } K_{d} \text { selection } \\
\text { of zones } 3,4,5 \text { and } 6 \text { has been completed }\end{array}$ & June 30,1999 \\
\hline 4 & Send out draft data package for internal Hanford review & July 1,1999 \\
\hline 5 & Get comments back from Hanford technical review & July 12,1999 \\
\hline 6 & Send out draft data package to DOE/BHI/LHMC & September 30,1999 \\
\hline 7 & Get comments back from other Hanford organizations & October 15,1999 \\
\hline 8 & Respond to Hanford reviewers' comments & October 31,1999 \\
\hline 9 & Send final Hanford reviewed draft to outside reviewers & October 8,1999 \\
\hline 10 & Respond to outside reviewers' first round of comments & November 15,1999 \\
\hline 11 & Respond to outside reviewers' $2^{\text {nd }}$ round of comments & December 10, 1999 \\
\hline 12 & $\begin{array}{l}\text { Get final/formal letter comments back from reviewers and complete } \\
\text { data package }\end{array}$ & December 31, 1999 \\
\hline
\end{tabular}




\subsection{References}

Allard, B., B. Torstenfelt, and K. Andersson. 1981. "Sorption Studies of $\mathrm{H}^{14} \mathrm{CO}_{3}$ - on Some Geologic Media and Concrete." In Scientific Basis for Nuclear Waste Management Vol. 3, pp. 465-472. Plenum Press, New York, New York.

Allard, B., L. Allicin, S. Hoglund, and K. Anderson. 1984. Sorption of Cs, I and Actinides in Concrete Systems. KGS 84-15. Swedish Nuclear Fuel and Waste Management Co., Stockholm, Sweden.

Amaia Sandino, M. C. and E. Osthols. 1999. Chemical Thermodynamics Series, Volume 3: Chemical Thermodynamics of Technetium. North-Holland, Elsevier Science Publishing Company, Inc., New York, New York.

Ames, L. L. and D. Rai. 1978. Radionuclide Interactions with Rock and Soil Media. Volume I. PB292460. U. S. Environmental Protection Agency, Office of Radiation Programs, Las Vegas, Nevada.

Ames, L. L. and R. J. Serne. 1991. Compilation of Data to Estimate Groundwater Migration Potential for Constituents in Active Liquid Discharges at the Hanford Site. PNL-7660. Pacific Northwest Laboratory, Richland, Washington.

Ames, L. L., J. E. McGarrah, B. A. Walker, and P. F. Salter. 1982. "Sorption of Uranium and Cesium by Hanford Basalts and Associated Secondary Smectites." Chem. Geol. 35:205-225.

Andreyev, P. F. and A. P. Chumachenko. 1964. "Reduction of Uranium by Natural Organic Substances." Geochem. Int. 1:3-7.

Angus, M. J. and F. P. Glasser. 1985. "The Chemical Environment in Cement Matrices." In Scientific Basis for Nuclear Waste Management IX, ed. L. O. Werme, pp. 547-556. Material Research Society Symposium Proceedings, Volume 50. Material Research Society, Pittsburgh, Pennsylvania.

Atkinson, A. and A. K. Nickerson. 1988. "Diffusion and Sorption of Cesium, Strontium, and Iodine in Water-Saturated Cement." Nuclear Technology. 81:100-113.

Baes, C. J., Jr. and R. E. Mesmer. 1976. The Hydrolysis of Cations. John Wiley, New York.

Barney, G. S. 1978. Variables Affecting Sorption and Transport of Radionuclides in Hanford Subsoils. RHO-SA-87. Rockwell Hanford Operations, Richland, Washington.

Bayliss, S., A. Haworth, R. McCrohon, A. D. Moreton, P. Oliver, N. J. Pilkington, A. J. Smith, and J. L. Smith-Briggs. 1991. "Radioelement Behavior in a Cementitious Environment." In Scientific Basis for Nuclear Waste Management XV, ed. C. G. Sombret, pp. 641-648. Materials Research Society Symposium Proceedings, Volume 257. Materials Research Society, Pittsburgh, Pennsylvania.

Bayliss, S., F. T. Ewart, R. M. Howse, S. A. Lane, N. J. Pilkington, J. L. Smith-Briggs, and S. J. Williams. 1989. "The Solubility and Sorption of Radium and Tin in a Cementitous Near-Field 
Environment." In Scientific Basis for Nuclear Waste Management XII, ed. W. Lutze and R. C. Ewing, pp. 879-885. Materials Research Society Symposium Proceedings, Volume 127. Materials Research Society, Pittsburgh, Pennsylvania.

Benjamin, M. M. and N. S. Bloom. 1981. "Effects of Strong Binding of Anionic Adsorbates on Adsorption of Trace Metals on Amorphous Iron Oxhydroxide." In Adsorption from Aqueous Solutions, ed. P. H. Tewari, pp. 41-60. Plenum Press, New York, New York.

Benson, D. W. 1961. Mineral Adsorption of Radionuclides in Reactor Effluent. HW-69225. General Electric Company, Hanford Atomic Products Operation, Richland, Washington.

Berner, U. R. 1992. "Evolution of Pore Water Chemistry During Degradation of Cement in a Radioactive Waste Repository." Waste Management. 12:201-219.

Birch, L. D. and R. Bachofen. 1990. "Effects of Microorganisms on the Environmental Mobility of Radionuclides." In Soil Biochemistry: Volume 6, eds. J. M. Bollag and G. Stotzky, pp. 101-124. Marcel Dekker, Inc., New York.

Boggs, S., Jr., D. Livermore, and M. G. Seitz. 1985. Humic Substances in Natural Waters and their Complexation with Trace Metals and Radionuclides: A Review. ANL-84-78. Argonne National Laboratory, Argonne, Illinois.

Bondietti, E. A. and C. W. Francis. 1979. "Geologic Migration Potentials of Technetium-99 and Np-237." Sci. 203:1337.

Borovec, Z., B. Kribek, and V. Tolar. 1979. "Sorption of Uranyl by Humic Acids." Chem. Geol. 27:39-46.

Bouwer, H. 1991. "Simple Derivation of the Retardation Equation and Application to Preferential Flow and Macrodispersion." Ground Water 29:41-46.

Bowen, H. J. N. 1966. Trace Elements in Biochemistry. Academic Press, London.

Box, G. E. P., and D. W Behnken. 1960. "Some New Three Level Designs for the Study of Quantitative Variables." Techometrics. 2:455-475.

Bradbury, M. H. and F. A. Sarott. 1995. Sorption Databases for the Cementitious Near-Field of a L/ILW Repository for Performance Assessment. PSI Bericht Nr. 95-06, Paul Scherrer Institute, Wurenligen and Villigen, Switzerland.

Brady, P. V. and M. W. Kozak. 1995. "Geochemical Engineering of Low Level Radioactive Waste in Cementitious Environments." Waste Management. 15:293-301.

Brodda, B. G. 1988. "Leachability of Technetium from Concrete." The Science of the Total Environment. 69:319-345. 
Bruno, J., I. Casa, and I. Puigdomenech. 1988. "The Kinetics of Dissolution of $\mathrm{UO}_{2}$ (s) Under Reducing Conditions." Radiochim. Acta. 11:44-45.

Bruno, J., I. Casa, and I. Puigdomenech. 1991. "The Kinetics of Dissolution of $\mathrm{UO}_{2}$ Under Reducing Conditions and the Influence of an Oxidized Surface Layer $\left(\mathrm{UO}_{2+\mathrm{x}}\right)$ : Application of a Continuous FlowThrough Reactor." Geochim. Cosmochim. Acta. 55:647-658.

Cataldo, D. A., R. E. Wildung, and T. R. Garland. 1978. "Technetium Accumulation, Fate, and Behavior in Plants." In Environmental Cycling Processes, Eds. D. C. Adriano and I. L. Brisbin, pp.207-220. University of Georgia, Athens, Georgia.

Cochran, G. W., and G. M. Cox. 1957. Experimental Design. 2nd ed. Wiley, New York.

Cotton, F. A., and G. Wilkinson. 1972. Advanced Inorganic Chemistry, A Comprehensive Text, $3^{r d}$ Edition. John Wiley and Sons, Inc., New York.

Coughtrey, P. J., D. Jackson, and M. C. Thome. 1983. "Radionuclide Distribution and Transport in Terrestrial and Aquatic Ecosystems. A Critical Review of Data." ECSC, EEC, EAEC, Brussels and Luxembourg.

Davies, O. L. 1954. Design and Analysis of Industrial Experiments. Hafner, New York.

Davis, J. A., J. A. Coston, D. B. Kent, and C. C. Fuller. 1998. "Application of the Surface Complexation Concept to Complex Mineral Assemblages." Environ. Sci. Technol. 32:2820-2828.

Delegard, C. H., and G. S. Barney. 1983. Effects of Hanford High-Level Waste Components on Sorption of Cobalt, Strontium, Neptunium, Plutonium, and Americium of Hanford Sediments. RHO-RE-ST-1 P, Rockwell Hanford Operations, Richland, Washington.

Ewart, F., S. Pugh, S. Wisbey, and D. Woodwark. 1988. Chemical and Microbiological Effects in the Near-Field: Current Status. Report NSS/G103, U.K. Nirex Ltd., Harwell, United Kingdom.

Ewart, F. T., J. L. Smith-Briggs, H. P. Thomason, and S. J. Williams. 1992. "The Solubility of Actinides in a Cementitious Near-Field Environment." Waste Management. 12:241-252.

Frost, R. R. and R. A. Griffin. 1977. "Effect of $\mathrm{pH}$ on Adsorption of Copper, Zinc, and Cadmium from Landfill Leachate by Clay Minerals." J. Environ. Sci. Health. A12:139-156.

Gamerdinger, A. P., D. I. Kaplan, and C. T. Resch. 1998. Uranium (VI) Sorption and Transport in Unsaturated, Subsurface Hanford Site Sediments - Effect of Moisture Content and Sediment Texture. PNNL-1 1975. Pacific Northwest National Laboratory, Richland, Washington.

Garnier, J. M. 1985. "Retardation of Dissolved Radiocarbon Through a Carbonated Matrix." Geochim. Cosmochim. Acta. 49:683-693. 
Geering, H. R., E. E. Cary, L. H. P. Jones, and W. H. Allaway. 1968. "Solubility and Redox Criteria for the Possible Forms of Selenium in Soils." Soil Sci. Soc. Am. Proc. 32:35-40.

Gilliam, T. M., R. D. Spence, B. S. Evans-Brown, I. L. Morgan, J. L. Shoemaker, and W. D. Bostick. 1989. "Performance Testing of Blast Furnace Slag For Immobilization of Technetium in Grout." In Nuclear and Hazardous Waste Management Spectrum '88, pp. 109-111. American Nuclear Society, La Grange Park, Illinois.

Grenthe, I. 1992. Chemical Thermodynamics of Uranium. North-Holland, New York.

Grenthe, I., J. Fuger, R. J. M. Konings, R. J. Lemire, A. B. Muller, C. Nguyen-Trung, and H. Wanner. 1992. Chemical Thermodynamics Series, Volume 1: Chemical Thermodynamics of Uranium. (Eds.) Wanner, H. and I. Forest, North-Holland, Elsevier Science Publishing Company, Inc., New York, New York.

Gu, B. and R. K. Schulz. 1991. Anion Retention in Soil: Possible Application to Reduce Migration of Buried Technetium and Iodine. NUREG/CR-5465. U. S. Nuclear Regulatory Commission, Washington, D.C.

Hamby, A. A. and G. Gissel-Nelson. 1977. "Fixation of Selenium by Clay Minerals and Iron Oxides." Z. Pflanzenernaehr. Bodenkd. 140,1:63-70.

Hanke, K., B. Jahrling, and K. J. Lieser. 1986. "Properties and Solubility of Technetium Dioxide." In Technetium in the Environment, Eds. G. Desment and C. Myttenaere, pp. 179-187. Elsevier Applied Science Publishers, Amsterdam.

Hartman, M. J. and P. E. Dresel (eds.). 1997. Hanford Site Groundwater Monitoring for Fiscal Year 1996. PNNL-1 1470. Pacific Northwest National Laboratory, Richland, Washington.

Hietanen, R., E. Kamarainen, and M. Alaluusua. 1984. Sorption of Strontium, Cesium, Nickel, Iodine and Carbon in Concrete. YJT-84-04. Nuclear Waste Commission of the Finnish Power Companies, Helsinki, Finland.

Hietanen, R., T. Jaakkola, and J. Miettinent. 1985. "Sorption of Cesium, Strontium, Iodine, and Carbon in Concrete and Sand." In Scientific Basis for Nuclear Waste Management VIII, Eds. C. M. Jantzen, J. A. Stone, and R. C. Ewing, pp. 891-898. Materials Research Society Symposium Proceedings, Volume 44. Materials Research Society, Pittsburgh, Pennsylvania.

Hingston, F. J., A. M. Posner, and J. P. Quirk. 1968. "Adsorption of Selenite by Goethite." Adv. Chem. Series. 79:82-90.

Hingston, F. J., A. M. Posner, and J. P. Quirk. 1971. "Competitive Adsorption of Negatively Charged Ligands on Oxide Surfaces." Disc. Faraday Soc. 52:234-342.

Hingston, F. J., A. M. Posner, and J. P. Quirk. 1972. "Anion Adsorption by Goethite and Gibbsite. The Role of the Proton in Determining Adsorption Envelopes." J. Soil Sci. 23:177-192. 
Hoglund, S., L. Eliasson, B. Allard, K. Anderson, and B. Torstenfelt. 1985. "Sorption of Some Fission Products and Actinides in Concrete Systems." In Scientific Basis for Nuclear Waste Management IX, ed. L. O. Werme, pp. 683-690. Materials Research Society Symposium Proceedings, Volume 50. Materials Research Society, Pittsburgh, Pennsylvania.

Hollander, M. and D. A. Wolfe. 1973. Nonparametric Statistical Methods. Wiley, New York.

Hsi, C-K. D. and L. Langmuir. 1985. "Adsorption of Uranyl onto Ferric Oxyhydroxides: Application of the Surface Complexation Site-binding Model." Geochem. Cosmochim. Acta. 49:1931-1941.

Idiz, E. F., D. Carlisle, and I. R. Kaplan. 1986. "Interaction Between Organic Matter and Trace Metals in a Uranium Rich Bog, Kem County, California, U.S.A." Appl. Geochem. 1:573-590.

Jenne, E. A., editor. 1998. Metal Adsorption by Geomedia. Academic Press, San Diego.

John, M. K., W. M. N. Saunders, and J. H. Watkinson. 1976. "Selenium Adsorption by New Zealand Soils I. Relative Adsorption of Selenite by Representative Soils and Relationship to Soil Properties. New Zealand. J. Agr. Res. 19:143-151.

Johnston, H. M., and D. J. Wilmot. 1992. "Sorption and Diffusion Studies in Cementitious Grouts." Waste Management. 12:289-297.

Kaplan, D. I. and R. J. Serne. 1995. Distribution Coefficient Values Describing Iodine, Neptunium, Selenium, Technetium, and Uranium Sorption to Hanford Sediments. PNL-10379, Sup. 1. Pacific Northwest Laboratory, Richland, Washington.

Kaplan, D. I., R. J. Serne, and M. G. Piepho. 1995. Geochemical Factors Affecting Radionuclide Transport Through Near and Far Field at a Low-Level Waste Disposal Site. PNL-10379. Pacific Northwest Laboratory, Richland, Washington.

Kaplan, D. I., R. J. Serne, A. T. Owen, J. A. Conca, T. W. Wietsma, and T. L. Gervais. 1996. Radionuclide Adsorption Distribution Coefficients Measured in Hanford Sediments for the Low Level Waste Performance Assessment Project. PNNL-11385. Pacific Northwest National Laboratory, Richland, Washington.

Kaplan, D. I., T. L. Gervais, and K. M. Krupka. 1998a. "Uranium(VI) sorption to Sediments Under High pH and Ionic Strength Conditions." Radiochimica Acta. 80:201-211.

Kaplan, D. I., K. E. Parker, and R. D. Orr. 1998b. Effects of High-pH and High-Ionic strength Groundwater on Iodide, Pertechnetate, and Selenate Sorption to Hanford Sediments. PNNL-11964. Pacific Northwest National Laboratory, Richland, Washington.

Kaplan, D. I., K. E. Parker, and I. V. Kutnyakov. 1998c. Radionuclide Distribution Coefficients for Sediments Collected from Borehole 299-E17-21: Final Report for Subtask 1a. PNNL-1 1996. Pacific Northwest National Laboratory, Richland, Washington. 
Kaplan, D. I., R. J. Serne, K. E. Parker, and I. V. Kutnyakov. 1999. "Iodide Sorption to Subsurface Sediments and Illitic Minerals." Environ. Sci. Technol. 34:399-405.

Kato, S. and Y. Yanase. 1993. Distribution Coefficients of Radionuclides in Concrete Waste for Coastal Soil and Concrete Powder. JAERI-M 93-113. Japan Atomic Energy Research Institute, Ibaraki-ken, Japan.

Keller, C. 1971. The Chemistry of the Transuranium Elements. Vol. 3. Kernchemie in Einzeldarstellunge. Verlag Chemie GmbH. Munchen.

Kent, D. B, V. S. Tripathi, N. B. Ball, J. O. Leckie, and M. D. Siegel. 1988. Surface-Complexation Modeling of Radionuclide Adsorption in Subsurface Environments. NUREG/CR-4807 and SAND86-7175. U. S. Nuclear Regulatory Commission, Washington, D.C.

Khaleel, R. 1999. Far-Field Hydrology Data Package for Immobilized Low-Activity Tank Waste Performance Assessment. HNF-4769, Rev. 1, Fluor Daniel Northwest, Inc., Richland, Washington.

Krupka, K. M. and R. J. Serne. 1998. Effects on Radionuclide Concentrations by Cement/Groundwater Interactions in Support of Performance Assessment of Low-Level Radioactive Waste Disposal Facilities. NUREG/CR-6377, PNNL-1 1408. Pacific Northwest National Laboratory, Richland, Washington.

Langmuir, D. 1978. "Uranium Solution-Mineral Equilibria at Low Temperatures with Applications to Sedimentary Ore Deposits." Geochim. Cosmochim. Acta. 42:547-569.

Langmuir, D. 1979. "Techniques of Estimating Thermodynamic Properties for Some Aqueous Complexes of Geochemical Interest." In Chemical Modeling in Aqueous Systems, ed. E. A. Jenne, pp. 353-387. American Chemical Society, Washington, D.C.

Leckie, J. O, M. M. Benjamin, K. Hayes, G. Kaufman, and S. Altman. 1980. Adsorption/Coprecipitation of Trace Elements from Water with Iron Oxhydroxide. EPRI-RP-910. Electric Power Research Institute, Palo Alto, California.

Lindenmeier, C. W., R. J. Serne, J. L. Conca, A. T. Owen, and M. I. Wood. 1995. Solid Waste Leach Characteristics and Contaminant-Sediment Interactions Volume 2: Contaminant Transport Under Unsaturated Moisture Contents. PNL-10722. Pacific Northwest National Laboratory, Richland, Washington.

Macalady, D. L., P. G. Tratnyek, and T. J. Grundl. 1986. "Abiotic Reduction Reactions of Anthropogenic Organic Chemicals in Anaerobic Systems: A Critical Review." J. Contam. Hydrol. 1:1-28.

Mann, F. M., R. J. Puigh, II, P. D. Rittmann, N. W. Kline, J. A. Voogd, Y. Chen, C. R. Eiholzer, C. T. Kincaid, B. P. McGrail, A. H. Lu, G. F. Williamson, N. R. Brown, and P. E. LaMont. 1998. Hanford Immobilized Low-Activity Tank Waste Performance Assessment. DOE/RL-97-69, Rev. 0. U.S. Department of Energy, Richland Operations Office, Richland, Washington. 
Martin, W. J. 1996. Integration of Risk Analysis and Sorption Studies in the Subsurface Transport of Aqueous Carbon-14 at the Hanford Site. Ph. D. Dissertation, Washington State University, Pullman, Washington.

Mattigod, S. V., D. I. Kaplan, V. L. LeGore, R. D. Orr, H. T. Schaef, and J. S. Young. 1998. Radionuclide Incorporation in Secondary Crystalline Minerals Resulting from Chemical Weathering of Selected Waste Glasses. PNNL-12005. Pacific Northwest National Laboratory, Richland, Washington.

McGrail, B. P., D. H. Bacon, J. P. Icenhower, W. L. Ebert, P. F. Martin, H. T. Schaef, and E. A. Rodriguez. 1999. Waste Form Release Data Package for the 2001 Immobilized Low-Activity Waste Performance Assessment. PNNL-13043, Pacific Northwest National Laboratory, Richland, Washington.

McGraw, M. A., and D. I. Kaplan. 1997. Colloid Suspension Stability and Transport Through Unsaturated Porous Media. PNNL-11565. Pacific Northwest National Laboratory, Richland, Washington.

Mozeto, A. A., P. Fritz, and E. J. Reardon. 1983. "Experimental Observation of Carbon Isotope Exchange in Carbonate-Water System." Geochim. Cosmochim. Acta. 48:495-504.

Mucciard, A. N., I. J. Booker, E. C. Orr, and D. Cleveland. 1979. "Statistical Investigation of the Mechanics Controlling Radionuclide Sorption, Part II." In Task 4, Second Contractor Information Meeting, ed. R. J. Serne, Vol. 2, pp. 333-425. PNL-SA-7352. Pacific Northwest Laboratory, Richland, Washington.

Mucciard, A. N., T. C. Johnson, and J. Saunier. 1980. Statistical Investigation of the Mechanics Controlling Radionuclide Sorption, Part III. In Task 4, Third Contractor Information Meeting, ed. J. F. Relyea, Vol. 1, pp. 1-75. PNL-SA-8571. Pacific Northwest Laboratory, Richland, Washington.

Muramatsu, Y., S. Uchida, P. Sriyotha, and K. Sriyotha. 1990. "Some Considerations of the Sorption and Desorption Phenomena of Iodide and Iodate on Soil." Water, Air, and Soil Pollution. 49:125-138.

Nakashima, S., J. R. Disnar, A. Perruchot, and J. Trichet. 1984. "Experimental Study of Mechanisms of Fixation and Reduction of Uranium by Sedimentary Organic Matter Under Diagenetic or Hydrothermal Conditions." Geochim. Cosmochim. Acta. 48:2321-2329.

Nash, K., S. Fried, A. M. Freidman, and J. C. Sullivan. 1981. "Redox Behavior, Complexing, and Adsorption of Hexavalent Actinides by Humic Acid and Selected Clays." Environ. Sci. Technol. 15:834-837.

Nelson, J. L. 1959. Soil Column Studies with Radiostrontium. Effects of Temperature and of Species of Accompany Ion. HW-62035. General Electric Company, Richland, Washington.

Parson, R. 1982. “Surface Properties of Oxides.” J. Electroanal. Chem. 118:2-18.

Pilkington, N. J. 1990. "The Solubility of Technetium in the Near-Field Environment of a Radioactive Waste Repository." J. Less-Common Metals. 161:203-211. 
Pilkington, N. J. and N. S. Stone. 1990. The Solubility and Sorption of Nickel and Niobium under High pH Conditions. NSS/R-186. Harwell Laboratory, Oxfordshire, England.

Plackett, R. L., and J. P. Burman. 1946. "The Design of Optimum Multifactorial Experiments." Biometrika 33:305-325.

Pourbaix, M. 1966. Atlas of Electrochemical Equilibria. Pergamon Press, Oxford, England.

Prout, W. E. 1959. Adsorption of Fission Products by Savannah River Plant Soil. DP-394. Savannah River National Laboratory, Aiken, South Carolina.

Rai, D., and J. M. Zachara. 1984. Chemical Attenuation Rates, Coefficients and Constants in Leachate Migration. EPRI EA-3356. Electric Power Research Institute, Pal Alto, California.

Rai, D., A. R. Felmy, and J. L. Ryan. 1990. "Uranium(IV) Hydrolysis Constants and Solubility Product of $\mathrm{UO}_{2} \cdot \mathrm{xH}_{2} \mathrm{O}(\mathrm{am})$." Inorg. Chem. 29:260-254.

Rajan, S. S. 1979. "Adsorption of Selenite, Phosphate, and Sulfate on Hydrous Alumina." J. Soil Sci. 30:709-718.

Ramsay, J. D. F. 1988. The Role of Colloids in the Release of Radionuclides from Nuclear Waste. Radiochimica Acta 44/45:165-170.

Rancon, D. 1973. "The Behaviour in Underground Environments of Uranium and Thorium Discharged by the Nuclear Industry." In Environmental Behavior of Radionuclides Released in the Nuclear Industry, pp. 333-346. IAEA-SM-172/55. IAEA, Vienna, Switzerland.

Reidel, S. P., K. D. Reynolds, and D. G. Horton. 1998. Immobilized Low-Activity Waste Site Borehole 299-E17-21. PNNL-11957. Pacific Northwest National Laboratory, Richland, Washington.

Rhoades, K., B. N. Bjomstad, R. E. Lewis, S. S. Teel, K. J. Cantrell, R. J. Serne, L. H. Sawyer, J. L. Smoot, J. E. Smoot, J. E. Szecsody, M. S. Wigmosta, and S. K. Wurstner. 1994. Estimation of the Release and Migration of Nickel Through Soils and Groundwater at the Hanford Site 218-E-12B Burial Ground. PNL-9791. Pacific Northwest Laboratory, Richland, Washington.

Rhodes, D. W. 1957a. "The Effect of pH on the Uptake of Radioactive Isotopes from Solution by a Soil." Soil Sci. Soc. Am. Proc. 21:389-392.

Rhodes, D. W. 1957b. "The Adsorption of Pu by Soil." Soil Sci. 84:465-471.

Rhodes, D. W. and J. L. Nelson. 1957. Disposal of Radioactive Liquid Wastes from the Uranium Recovery Plant. HW-54721, HW-67201. General Electric Company, Richland, Washington.

Robertson, D. E. 1974. Physicochemical Characterization of N-Reactor Effluent Radionuclides in Soil and Water Systems. BNWL-1950. Pacific Northwest Laboratories, Richland, Washington. 
Routson, R. C., and R. J. Serne. 1972. One-Dimensional Model of the Movement of Trace Radioactive Solute Through Soil Columns: The PERCOL Model. BNWL-1718, Pacific Northwest Laboratory, Richland, Washington.

Routson, R. C., G. Jansen, and A. V. Robinson. 1976. "241-Am, 237-Np, and 99-Tc sorption on Two United States Subsoils from Differing Weathering Intensity Areas." Health Phys. 33:311-317.

Routson, R. C., G. S. Barney, R. O. Seil. 1978. Measurement of Fission Product Sorption Parameters for Hanford 200 Area Sediment Types. Progress Report. RHO-LD-73. Rockwell Hanford Operations, Richland Washington.

Routson, R. C., G. S. Barney, R. H. Smith, C. H. Delegard, and L. Jensen. 1981. Fission Product Sorption Parameters for Hanford 200-Area Sediment Types. RHO-ST-35, Rockwell Hanford Operations, Richland, Washington.

Sandino, A., and J. Bruno. 1992. "The Solubility of (UO2)3(PO4)2-H2O(s) and the Formation of U(VI) Phosphate Complexes: Their Influence in Uranium Speciation in Natural Waters." Geochim. Cosmochim Acta 56:4135-4143.

Sarott, F. A., M. H. Bradbury, P. Pandjolfo, and P. Spieler. 1992. "Diffusion and Absorption Studies on Hardened Cement Paste and the Effect of Carbonation on Diffusion Rates." Cement and Concrete Research. 22:439-444.

Schindler, P. W., and G. Sposito. 1991. "Surface Complexation at (Hydro)oxide Surfaces.” Pp. 115-145. In Interactions at the Soil Colloid-Soil Solution Interface. G. H. Bolt, M. F. DeBoodt, M. H. B. Hayes, and M. B. Mc Bride (eds.). Kluwer Academic P.

Schulte, E. H. and P. Scoppa. 1987. "Sources and Behavior of Technetium in the Environment." Sci. Total Environ. 64:163-168.

Serne, R. J. 1990. "Grouted Waste Leach Tests: Pursuit of Mechanisms and Data for Long-Term Performance Assessment." In Scientific Basis for Nuclear Waste Management XIII, eds. V. M. Oversby and P. W. Brown, pp. 91-99. Materials Research Society Symposium Proceedings, Volume 176. Materials Research Society, Pittsburgh, Pennsylvania.

Serne, R. J. and J. F. Relyea. 1983. "The Status of Radionuclide Sorption-Desorption Studies Performed by the WRIT Program." In The Technology of High-Level Nuclear Waste Disposal, Vol. 1, pp. 203-254. DOE/TIC-621. Technical Information Center, U. S. Department of Energy, Oak Ridge, Tennessee.

Serne, R. J., R. C. Routson, and D. A. Cochran. 1973. Experimental Methods for Obtaining PERCOL Model Input Verification Data. BNWL-1721, Pacific Northwest Laboratory, Richland, Washington.

Serne, R. J., R. O. Lokken, and L. J. Criscenti. 1992. "Characterization of Grouted Low-Level Waste to Support Performance Assessment." Waste Management. 12:271-288. 
Serne, R. J., J. L. Conca, V. L. LeGore, K. J. Cantrell, C. W. Lindenmeier, J. A. Campbell, J. E. Amonette, and M. I. Wood. 1993. Solid-Waste Leach Characteristics and Contaminant-Sediment Interactions. Volume 1: Batch Leach and Adsorption Tests and Sediment Characterization. PNL-8889, Vol 1. Pacific Northwest Laboratory, Richland, Washington.

Serne, R. J., D. Rai, P. F. Martin, A. R. Felmy, L. Rao, and S. Ueta. 1996. "Leachability of Nd, U, Th, and $\mathrm{Sr}$ From Cements in a $\mathrm{CO}_{2}$ Free Atmosphere." in Scientific Basis for Nuclear Waste Management $X I V$, editors W. M. Murphy and D. A. Knecht, Materials Research Society. Pittsburgh, Pennsylvania. Vol 412: $459-467$.

Serne, R. J., J. M. Zachara, and D. S. Burke. 1998. Chemical Information on Tank Supernatants, Cs Adsorption From Tank Liquids Onto Hanford Sediments, and Field Observations of Cs Migration From Past Tank Leaks. PNNL-11495. Pacific Northwest National Laboratory, Richland, Washington.

Serne, R. J., D. S. Burke, and K. M. Krupka. 1999. Uranium Solubility Tests in Support of Solid Waste Burial. PNNL-12242. Pacific Northwest National Laboratory, Richland, Washington.

Shanbhag, P. M. and G. R. Choppin. 1981. "Binding of Uranyl by Humic Acid." J. Inorg. Nucl. Chem. 43:3369-3375.

Sheppard, J. C., J. A. Kittrick, and T. L. Hart. 1976. Determination of Distribution Ratios and Diffusion Coefficients of Neptunium, Americium, and Curium in Soil-Aquatic Environments. RLO-221-T-12-2. Rockwell Hanford Operations, Richland, Washington.

Sheppard, S. C., M. I. Sheppard, and W. G. Evenden. 1990. "A Novel Method Used to Examine Variation in Tc Sorption Among 34 Soils, Aerated and Anoxic." J. Environ. Radioact. 11:215-2121.

Silva, R. J., G. Bidoglio, M. H. Rand, P. B. Robouch, H. Wanner, and I. Puigdomenech. 1995. Chemical Thermodynamics Series, Volume 2: Chemical Thermodynamics of Americium. North-Holland, Elsevier Science Publishing Company, Inc., New York, New York.

Singh, M., N. Singh, and P. S. Realan. 1981. "Adsorption and Desorption of Selenite and Selenate Selenium on Different Soils." Soil Science. 132:134-141.

Snedecor, G. W., and W. C. Cochran. 1967. Statistical Methods. 6th ed. Iowa State University Press, Ames, Iowa.

Sposito, G. 1984. The Surface Chemistry of Soils. Oxford University Press, New York.

Stalmans, M., A. Maes, and A. Cremers. 1986. "Role of Organic Matter as a Geochemical Sink for Technetium in Soils and Sediments." In Technetium in the Environment, eds. G. Desmet and C. Myttenaere, pp. 91-113. Elsevier Applied Science Publishers, Amsterdam.

Striegl, R: G. and D. E. Armstrong. 1990. "Carbon Dioxide Retention and Carbon Exchange on Unsaturated Quaternary Sediments." Geochim. Cosmochim. Acta. 54:2277-2283. 
Stumm, W. and J. J. Morgan. 1981. Aquatic Chemistry. An Introduction Emphasizing Chemical Equilibria in Natural Waters. $2^{\text {nd }}$ Edition, John Wiley \& Sons, New York.

Tallent, O. K., E. W. McDaniel, G. D. Del Cul, K. E. Dodson, and D. R. Trotter. 1988. "Immobilization of Technetium and Nitrate in Cement-Based Materials." In Scientific Basis for Nuclear Waste Management XI, eds. M. J. Apted and R. E. Westerman, pp. 23-32. Materials Research Society Symposium Proceedings, Volume 112. Materials Research Society, Pittsburgh, Pennsylvania

Thibault, D. M., M. I. Sheppard, and P. A. Smith. 1990. A Critical Compilation $2^{\text {nd }}$ Review of Default Soil Solid/Liquid Partition Coefficients, $K_{d}$, For Use in Environmental Assessment. AECL-10125. White Shell Nuclear Research Establishment, Pinawa, Manitoba, Canada.

Ticknor, K. V. and Y. H. Cho. 1990. "Interaction of Iodide and Iodate with Granitic Fracture-Filling Minerals." J. Radioanal. Nuclear Chem. 140:75-90.

Valocchi, A. J. 1985. Validity of the Local Equilibrium Assumption for Modeling Sorbing Solute Transport Through Homogeneous Soils. Water Resour. Res. 21:808-820.

van Genuchten, M. Th. 1981. Non-equilibrium Transport Parameters from Miscible Displacement Experiments. Research Report 119. U.S. Salinity Laboratory, U.S. Department of Agriculture, Washington, D.C.

Van Loon, L., M. Stalmans, A. Maes, A. Cremers, and M. Cogneau. 1986. "Soil-Humic Acid Complexes of Technetium: Synthesis and Characterization." In Technetium in the Environments, eds. G. Desmet and C. Myttenaere, pp. 143-153. Elsevier Applied Science Publishers.

Walters, L. J., and J. W. Winchester. 1971. "Neutron Activation Analysis of Sediments for Halogens Using Szilard-Chalmers Reactions." Anal. Chem. 43:1020-1033.

Wang, F., J. Chen, and W. Forsling. 1997. "Modeling Sorption of Trace Metals on Natural Sediments by Surface Complexation Model." Environ. Sci. Technol. 31:448-453.

Westall, J. C. 1986. "Reactions at the Oxide-Solution Interface: Chemical and Electrostatic Models." In Geochemical Processes at Mineral Surfaces. ACS Symposium Series 323, pp. 54-78. American Chemical Society, Washington, D.C.

Westall, J. C. 1994. "Modeling of the Association of Metal Ions with Heterogeneous Environmental Sorbents." In XVIII International Symposium on the Scientific Basis for Nuclear Waste Management, pp. 1-12. Materials Research Society, Warrendale, Pennsylvania.

Westall, J. C., and H. Hohl. 1980. "A Comparison of Electrostatic Models for the Oxide Solution Interface." Adv. Colloid Interface Sci. 12:265-294.

Whitehead, D. C. 1973. "The Sorption of Iodide by Soils as Influenced by Equilibrium Conditions and Soil Properties." J. Sci. Food Agric. 24:547-556. 
Whitehead, D. C. 1974. "The Influence of Organic Matter, Chalk, and Sesquioxides on the Solubility of Iodide, Elemental Iodine, and Iodate Incubated with Soil." J. Soil Sci. 25:461-470.

Whitehead, D. C. 1984. "The Distribution and Transformations of Iodine in the Environment." Environ. Intern. 10:321-339.

Wildung, R. E., T. R. Garland, and D. A. Cataldo. 1977. "Accumulation of Technetium by Plants." Health Phys. 32:314-317.

Wildung, R. E., T. R. Garland, K. M. McFadden, and C. E. Cowen. 1986. "Technetium Sorption in Surface Soils." In Technetium in the Environment, eds. G. Desmet and C. Myttenaere, pp. 115-129. Elsevier Applied Science Publishers, Amsterdam.

Yeh, G., and V. S. Tripathi. 1991. "A Model for Simulating Transport of Reactive Multispecies Components: Model Development and Demonstration." Water Resour. Res. 27:3075-3094.

Zhang, J., P. O. Quay, and D. O. Wilbur. 1995. "Carbon Isotope Fractionation During Gas-Water Exchange and Dissolution of $\mathrm{CO}_{2}$." Geochim. Cosmochim. Acta. 59:107-114. 
Appendix A

A Less Conservative Approach to Correcting $K_{d}$ Values for the Presence of Gravel 


\section{Appendix A}

\section{A Less Conservative Approach to Correcting $K_{d}$ Values for the Presence of Gravel}

An alternative approach to correcting $\mathrm{K}_{\mathrm{d}}$ values that is less conservative than the approach used in the data package is provided. This approach was developed from a project conducted in conjunction with the ILAW PA. A manuscript of this research has been submitted for publication and is included in this appendix.

The equation used for gravel-corrected $\mathrm{K}_{\mathrm{d}}$ values was:

$$
K d_{g c, g=0}=(1-f) K d_{<2 m m}
$$

where $f$ equaled 0.9 . Thus, all the $\mathrm{K}_{d}$ values in the gravel-dominated sequence were reduced by an order of magnitude $(1-f=1-0.9=0.1)$. An alternative correction would be:

$$
K d_{g c, g=x}=(1-f) K d_{<2 m m}+(f) K d_{>2 m m}
$$

Equation A-1 underestimated actual $\mathrm{K}_{\text {dtotal }}$ by 28 to $47 \%$, whereas Equation A-2 slightly overestimated $\mathrm{K}_{\mathrm{dtotal}}$ by 3 to $5 \%$. Equation $\mathrm{A}-1$ is conservative and Equation 2 is not, although the difference between $\mathrm{K}_{\text {dotal }}$ and $\mathrm{K}_{\mathrm{dgc}, \mathrm{s}=\mathrm{x}}$ is not significant $(\mathrm{P}<0.05)$. Equation $\mathrm{A}-1$ becomes less and less accurate, i.e., the degree to which it underestimates $\mathrm{K}_{\text {dtotal }}$ increases, as the percent of gravel $(f)$ increases. At $f=0.9$, $\mathrm{K}_{\mathrm{dgc}, \mathrm{g}=0}$ will greatly underestimate the actual $\mathrm{K}_{\mathrm{dtotal}}$.

An attempt was made to apply Equation A-2 to the gravel corrections. We have laboratory data on Sr and $\mathrm{Cs}$ for $\mathrm{K}_{\mathrm{d}>2 \mathrm{~mm}}$, i.e., for 2 of the 26 radionuclides for which $\mathrm{K}_{d}$ data is needed for the data package. The ratio of $\mathrm{K}_{d>2 \mathrm{~mm}} / \mathrm{K}_{d<2 \mathrm{~mm}}$ for $\mathrm{Sr}$ and Cs were 0.23 and 0.42 , respectively.

Assuming all radionuclides have a $\mathrm{K}_{d>2 \mathrm{~mm}} / \mathrm{K}_{\mathrm{d}<2 \mathrm{~mm}}$ of 0.23 , we can rewrite Equation A-2 as:

$$
K d_{g c, g=x}=(1-f) K d_{<2 m m}+(f) 0.23 K d_{<2 m m}
$$

and then by setting $f=0.9$, this simplifies to:

$$
K d_{g c, g=x}=0.31 K d_{<2 m m}
$$

Thus, gravel corrected $\mathrm{K}_{d}$ values based on Equation $\mathrm{A}-4$ will be $210 \%$ greater than those based on Equation A-1. Equation A-4 is likely to provide a more accurate estimate than Equation A-1, especially at the high gravel concentrations needed for the PA. However, and perhaps more importantly, more uncertainty is associated with the approach presented in $A-4$, due to the lack of $K_{d<2 \mathrm{~mm}}$ for each radionuclide. 


\title{
DRAFT \\ Gravel-Corrected $\mathrm{K}_{d}$ Values
}

\author{
Daniel I. Kaplan ${ }^{a}$, Igor V. Kutnyakov ${ }^{b}$, Amy P. Gamerdinger ${ }^{c}$, R. Jeff Serne ${ }^{b}$, \\ Kent E. Parker ${ }^{b}$ \\ ${ }^{2}$ Westinghouse Savannah River Company, Aiken, SC 29808. (803) 725-2363. \\ ${ }^{b}$ Pacific Northwest National Laboratory, Mailstop K6-81, Richland, WA 99352. (803) 376-5952. \\ ${ }^{c}$ Washington State University, Department of Chemistry, Richland, WA 99352. (803) 373-3077.
}

\author{
Submitted September 1, 1999 \\ to Ground Water
}

\begin{abstract}
Standard measurements of solute sorption to sediments are typically made on the $<2-\mathrm{mm}$ sediment fraction. This fraction is used by researchers to standardize the method, and to ease experimental protocol, whereby large labware is not required to accommodate the large gravel fraction ( $>2-\mathrm{mm}$ particles). Since sorption is a phenomenon directly related to surface area, sorption measurements based on the $<2$-mm fraction would be expected to underestimate actual whole-sediment values for sediments containing gravel. This inaccuracy, referred to as the Gravel- $K_{d}$ Issue, is a problem for ground water contaminant transport modelers who use laboratory-derived sorption values, typically expressed as a distribution coefficients $\left(\mathrm{K}_{\mathrm{d}}\right)$, to calculate the retardation factor $(\mathrm{Rf})$, a parameter that accounts for solutesediment chemical interactions. The objectives of this laboratory study were to quantify the effect of gravel on $K_{d}$ and $R f$ values and to develop an empirical method to calculate gravel-corrected $K_{d}$ values. Three gravel corrections, $K_{d g c}$ values, were evaluated: 1) a correction based on the assumption that the gravel simply diluted the $\mathrm{K}_{\mathrm{d}<2 \mathrm{~mm}}$ and had no sorption capacity $\left(\mathrm{K}_{\mathrm{dgc}, \mathrm{g}=0}\right)$, 2) a correction based on the assumption that the $\mathrm{K}_{\mathrm{d}}$ of the intact sediment $\left(\mathrm{K}_{\mathrm{dtot}}\right)$ was a composite of the $\mathrm{K}_{\mathrm{d}<2 \mathrm{~mm}}$ and the $\mathrm{K}_{d>2 \mathrm{~mm}}\left(\mathrm{~K}_{\mathrm{dgc}-}\right.$ $g=x)$, and 3 ) a correction based on surface area $\left(\mathrm{K}_{\mathrm{dgc}, \text { surf }}\right)$. On average, $\mathrm{K}_{\mathrm{d}<2 \mathrm{~mm}}$ tended to overestimate $\mathrm{K}_{\mathrm{dtot}}$ by 28 to $47 \% ; K_{d g c, g=x}$ overestimated $K_{d t o t}$ by only 3 to $5 \% ; K_{d g c, o=0}$ and $K_{d g c, s u r f}$ underestimated $K_{d t o t}$ by 10 to $39 \%$. Although, $\mathrm{K}_{\mathrm{d} \text { gc-g=x }}$ provided the best estimate of actual values $\left(\mathrm{K}_{\mathrm{dtot}}\right), \mathrm{K}_{\mathrm{dgc}-\mathrm{g}=0}$ was appreciably easier to acquire. These results have important implications regarding the traditional approach to modeling contaminant transport which uses $\mathrm{K}_{\mathrm{d}<2 \mathrm{~mm}}$ values. Such calculations may overestimate the ability of gravel-containing sediments to retard contaminant migration, thereby overestimating lowerbounding limits of contaminant migration. Use of gravel-corrected $\mathrm{K}_{\mathrm{d}}$ values will improve such lowerbounding estimates.
\end{abstract}

\section{Introduction}

The extent that contaminants sorb to sediments is typically measured in the laboratory using a batch test in which the $<2-\mathrm{mm}$ particle size fraction of the sediment is placed into contact with an aqueous phase containing the contaminant of interest. The $<2-\mathrm{mm}$ fraction is used to standardize the method and to ease 
the experimental protocol, whereby large labware is not required to accommodate the gravel $(>2-\mathrm{mm}$ particles). The distribution coefficient, or $\mathrm{K}_{\mathfrak{d}}$ value, is the simplest construct describing contaminant sorption to sediments. It is the ratio of the contaminant concentration sorbed to the solid phase divided by the contaminant concentration in the liquid surrounding the solid phase (Equation 1):

$$
K d=\frac{C_{\text {solid }}}{C_{\text {liquid }}}
$$

where $C_{\text {solid }}\left(\mathrm{M} \mathrm{kg}^{-1}\right)$ and $C_{\text {liquid }}\left(\mathrm{M} \mathrm{L}^{-1}\right)$ are the concentration in the solid and liquid phases, respectively. Since sorption is typically a surface reaction phenomenon (Sposito 1984), the extent of sorption based on the $<2-\mathrm{mm}$ fraction will overestimate the true extent of sorption for the entire sediment, especially in sediments dominated by gravel.

The discrepancy between the laboratory $\mathrm{K}_{d}$ value and the true field value due to excluding the gravel from the laboratory samples is referred to as the "gravel- $\mathrm{K}_{\mathrm{d}}$ issue." Contaminant transport modelers commonly use $\mathrm{K}_{d}$ values to account for chemical interactions between the contaminant and the sediment. The $\mathrm{K}_{\mathrm{d}}$ value is used to define the retardation factor, which is the ratio of the average linear velocity of water (m $\left.\mathrm{s}^{-1}\right)$ divided by the average linear velocity of the contaminant $\left(\mathrm{m} \mathrm{s}^{-1}\right)$. The $\mathrm{K}_{\mathrm{d}}$ value is related to the retardation factor ( $R f$, unitless) by the bulk density $\left(\rho_{\mathrm{b}}, \mathrm{kg} \mathrm{m}^{-1}\right)$ and the porosity $\left(\eta, \mathrm{m}^{3} \mathrm{~m}^{-3}\right)$ as follows (Valocchi 1984, Bower 1991):

$$
R f=\left(1+\frac{K d \rho_{b}}{\eta}\right)
$$

As gravel concentrations in a sediment increase, the $K_{d}$ value would be expected to decrease because the specific surface area of the sediment decreases; the bulk density would be expected to increase. These changes in sediment properties have opposite effects on the magnitude of the retardation factor (Equation 2). Bulk density values in the subsurface typically vary between $2650 \mathrm{~kg} \mathrm{~m}^{-3}$ (the density of a solid quartz crystal) to $1180 \mathrm{~kg} \mathrm{~m}^{-3}$ (the density of closely packed clay-size particles). $\mathrm{K}_{\mathrm{d}}$ values of many metals and cationic radionuclides often vary by several orders of magnitude as a function of particle size (reviewed by Ames and Rai 1978 and Thibault et al. 1990). Thus, it is likely that the introduction of gravel to a system will cause the actual retardation factor to decrease because the $K_{d}$ values will decrease to a greater extent than bulk density values will increase. An important implication of this conclusion is that transport modelers using traditional $\mathrm{K}_{\mathrm{d}}$ values measured with the $<2$-mm sediment fraction will likely overestimate the ability of a gravel-containing sediment to retard contaminant movement, thereby overestimating lower-bounding limits of contaminant migration.

The objectives of this study were to: 1) quantify the effect of gravel on $\mathrm{K}_{\mathrm{d}}$ and $\mathrm{Rf}$ values, and 2) develop a method to calculate gravel-corrected $\mathrm{K}_{\mathrm{d}}$ values $\left(\mathrm{K}_{\mathrm{dgc}}\right)$. The intent of this research was to conduct batchsorption experiments to develop a $\mathrm{K}_{\mathrm{dgc}}$ that would be beneficial to contaminant transport modelers. Thus, we wanted the corrections to be based on the traditional $K_{d}$ value, $K_{d<2 \mathrm{~mm}}$, for which there is an extensive literature base. Also, any additional parameters needed for the correction had to be easily obtainable, which would rule out extensive solid phase characterization. 


\section{Materials and Methods}

Two laboratory experiments were conducted using similar experimental protocols. In the Natural Sediment Experiments, Sr sorption to various size fractions of eight natural, gravel-containing sediments was measured. In the Gravel-Amended Experiment, Sr sorption to sediments amended with varying amounts of gravel was measured. Three gravel corrections were evaluated: 1) a correction based on the assumption that the gravel simply diluted the $\mathrm{K}_{\mathrm{d}<2 \mathrm{~mm}}$ and had no sorption capacity $\left.\left(\mathrm{K}_{\mathrm{dgc}, \mathrm{g}=0}\right), 2\right)$ a correction based on the assumption that the $K_{d}$ of the intact sediment $\left(K_{d t o t}\right)$ was a composite of the $K_{d<2 \mathrm{~mm}}$ and the $\mathrm{K}_{d>2 \mathrm{~mm}}\left(\mathrm{~K}_{\mathrm{dgc}-\mathrm{g}=\mathrm{x}}\right)$, and 3$)$ a correction based on surface area $\left(\mathrm{K}_{\mathrm{dgc}, \text { surf }}\right)$. Strontium was selected as a trace solute because its geochemistry is relatively simple. It exists almost exclusively as the $\mathrm{Sr}^{2+} \mathrm{species}^{-}$ between $\mathrm{pH} 3$ to 9.5 and it sorbs to sediments almost exclusively by cation exchange (Ames and Rai 1978, Kaplan et al. 1998). It was anticipated that the relative simplicity of Sr geochemistry would ease data interpretation.

\section{General Sorption Procedure}

The general procedure used in the two experiments was identical. The solid phases (natural sediment or gravel-amended sediment) were first pre-equilibrated with an uncontaminated ground water collected from the Hanford Site located in Richland, Washington (Well 600-S3-25, Table 1). This was accomplished by adding the ground water to the solid phases (typically in a 40:1 solution to solid ratio), shaking the suspensions overnight, centrifuging, decanting the supernatant, and then measuring the supernatant $\mathrm{pH}$. This was repeated until the $\mathrm{pH}$ of the wash solution did not change by more than \pm 0.05 units before and after contact with the solid phase. Equilibration by this method typically required three washings. The purpose of the pre-equilibration step was to isolate the Sr-adsorption reaction from other reactions that may occur while sediments and solutions came to chemical equilibrium.

A portion of the equilibrated ground water solution was amended with $25-\mu \mathrm{Ci} \mathrm{L} \mathrm{L}^{-1}{ }^{85} \mathrm{Sr}$, as carrier-free $\mathrm{Sr}^{2+}$, and then mixed overnight on a platform shaker. The ${ }^{85} \mathrm{Sr}$-amended solution was then placed in contact with the solids. The solid-to-solution ratio was 1:30 (wt:wt). This relatively low solid-to-solution ratio provided optimal sensitivity for measuring $K_{d}$ values in the range of 10 to $30 \mathrm{~L} \mathrm{~kg}^{-1}$. The aqueous ${ }^{85} \mathrm{Sr} / \mathrm{sediment}$ suspensions were placed on a slow-moving platform shaker to equilibrate for 14 days. After equilibration, the suspensions were centrifuged and then passed through $0.45-\mu \mathrm{m}$ filters. The ${ }^{85} \mathrm{Sr}$ activity and $\mathrm{pH}$ of the filtrates were measured. The ${ }^{85} \mathrm{Sr}$ activity was measured with a germanium detector. All radiological counting was performed to a 3\% total error.

Distribution coefficients $\left(\mathrm{K}_{\mathrm{d}}, \mathrm{L} \mathrm{kg}^{-1}\right)$ were calculated using Equation 3. This equation accounts for the dilution of the initial ${ }^{85} \mathrm{Sr}$-amended solution by the interstitial ground water remaining in the sediment after the final pre-equilibrating wash (i.e., the ${ }^{85} \mathrm{Sr}$-free ground water left in the tube after preequilibration):

$$
K d=\frac{\left(C_{\text {initial }} \times V_{\text {initial }}\right)-C_{\text {final }}\left(V_{\text {initial }}+V_{\text {interstitial }}\right)}{C_{\text {final }} \times M_{\text {sediment }}}
$$

where $V_{\text {interstitial }}$ is the volume of the interstitial solution left after the final pre-equilibration wash (L), $M_{\text {sediment }}$ is the sediment mass (kg), $V_{\text {initial }}$ is the volume of the ${ }^{85} \mathrm{Sr}$-amended solution added to the sediment 
(L), $C_{\text {final }}$ is the ${ }^{85} \mathrm{Sr}$ concentration in the effluent solution after contact with the sediment $\left(\mathrm{Ci} \mathrm{L}^{-1}\right)$, and $C_{\text {initial }}$ is the ${ }^{85} \mathrm{Sr}$ concentration in the ${ }^{85} \mathrm{Sr}$-amended solution added to the solids $\left(\mathrm{Ci} \mathrm{L}{ }^{-1}\right)$.

Two types of control treatments were included in these experiments: a negative and a positive control. The positive control consisted of the ${ }^{85} \mathrm{Sr}$-amended aqueous phase, $\mathrm{C}_{\text {initial, }}$, and no solid phase. This control monitored Sr sorption to labware and filters. The negative control consisted of the solid and aqueous phases without added ${ }^{85} \mathrm{Sr}$. This control quantified the amount of ${ }^{85} \mathrm{Sr}$ in the uncontaminated aqueous and solid phases or introduced into the experiment through laboratory activities. Four replicates of controls and of each treatment were included in the experimental design.

The ground water used in this study was characterized by standard methods. Inductively coupled plasmaatomic emission spectroscopy (ICP-AES) was used to determine dissolved cation concentrations. It had an analytical precision of $\leq \pm 4 \%$ at $5 \mathrm{mg} \mathrm{L}^{-1}$ cation concentrations. Ion chromatography (IC) was used to determine dissolved anion concentrations. It had an analytical precision of $\leq \pm 4 \%$ at $5 \mathrm{mg} \mathrm{L}^{-1}$ anion concentrations. A carbon analyzer was used to determine total and inorganic carbon (Nelson 1987).

Sediment characterization was conducted using standard methods. Cation exchange capacity (CEC) was determined by the $\mathrm{Na}^{+}$- ion exchange method that is specifically designed for arid sediments (Rhodes 1987). Particle size distribution was determined by the sieve and pipette method (Gee and Bauder 1986). Bulk density and porosity were determined gravimetrically by repacking dry sediments in a column assembly (Klute and Dirksen 1996). $\mathrm{pH}$ was determined by the 1:1 solid:solution method (McLean 1987).

Three gravel corrections, $\mathrm{K}_{\mathrm{dgc}}$ values, were evaluated: a correction based on the assumption that the gravel simply diluted the $K_{d<2 \mathrm{~mm}}$ and had no sorption capacity $\left(\mathrm{K}_{\mathrm{dgc}, \mathrm{g}=0}\right)$, a correction based on surface area $\left.\mathrm{K}_{\mathrm{dgc}, \text { surf }}\right)$, and a correction based on the assumption that the $\mathrm{K}_{d}$ of the entire sediment $\left(\mathrm{K}_{\mathrm{dtot}}\right)$ was a composite of the $\mathrm{K}_{\mathrm{d}<2 \mathrm{~mm}}$ and the $\mathrm{K}_{\mathrm{d}>2 \mathrm{~mm}}$ values $\left(\mathrm{K}_{\mathrm{dgc}, \mathrm{g}=\mathrm{x}}\right)$. $\mathrm{K}_{\mathrm{dgc}, \mathrm{g}=0}$ was defined as:

$$
K d_{g c, g=0}=(1-f) K d_{<2 m m}
$$

where $f$ if the weight fraction of gravel in the total sediment.

$\mathrm{K}_{\mathrm{dgc}, \mathrm{g}=\mathrm{x}}$ was defined as:

$$
K d_{g c, g=x}=(1-f) K d_{<2 m m}+(f) K d_{>2 m m}
$$

One important disadvantage of $\mathrm{K}_{\mathrm{dgc}, g=\mathrm{x}}$ compared to $\mathrm{K}_{\mathrm{dgc}, g=0}$ is that it requires $\mathrm{K}_{\mathrm{d}>2 \mathrm{~mm}}$, a parameter that may be difficult to measure. The additive approach would be expected to overestimate the extent of actual sorption because it does not account for masking of sorption sites by particles contacting each other.

The definition of $\mathrm{K}_{\mathrm{dgc}, \mathrm{surf}}$ is:

$$
K d_{g c, \text { surf }}=(1-f)\left(K d_{<2 m m}\right)+(f)\left[\left(K d_{<2 m m}\right)\left(\frac{S A_{>2 m m}}{S A_{<2 m m}}\right)\right]
$$


where $\mathrm{SA}_{>2 \mathrm{~mm}}$ and $\mathrm{SA}_{<2 \mathrm{~mm}}$ is a specific surface-area estimate $\left(\mathrm{m}^{2} \mathrm{~kg}^{-1}\right)$ of the greater-than and less-than 2-mm fractions of the sediment, respectively (further defined below). The first term on the right side of Equation 6 is the weight-averaged $\mathrm{K}_{d}$ value of the $<2-\mathrm{mm}$ fraction. The second component on the right side of the equation accounts for the $\mathrm{Sr}$ sorption to the $>2-\mathrm{mm}$ fraction. Such a correction to the $\mathrm{K}_{d<2 \mathrm{~mm}}$ assumes that the sorptive surfaces and sorption site density of the $<2-\mathrm{mm}$ and $>2-\mathrm{mm}$ fractions are similar. Furthermore, it assumes that the cause for differences between $K_{d<2 \mathrm{~mm}}$ and $\mathrm{K}_{\mathrm{d}>2 \mathrm{~mm}}$ values is due to the differences in the surface areas of the $>2-\mathrm{mm}$ and $<2-\mathrm{mm}$ fractions. These may be reasonable simplifying approximations in systems where the surfaces are coated with Fe-oxyhydroxides, organic matter, or carbonates.

In the absence of direct measurement, specific surface area can be approximated by assuming spherical particles, and from the particle surface area, volume, and particle density,

$$
S A_{i}=\left(4 \pi r_{i}^{2}\right)\left[\left(\frac{1}{4 /\left(3 \pi r_{i}^{3}\right)}\right)\left(\frac{1}{\rho_{p-i}}\right)\right] \text {, }
$$

where $r$ is the average particle radius, $\rho_{p}$ is the particle density, and the subscript $i$ refers to either the $<2-\mathrm{mm}$ or $>2-\mathrm{mm}$ fraction. The term within the square brackets in Equation 7 converts the surface area of one particle $\left(\mathrm{m}^{2}\right.$ particle $\left.\mathrm{e}^{-1}\right)$ to the specific surface area of a particle $\left(\mathrm{m}^{2} \mathrm{~kg}^{-1}\right)$. By assuming that $\rho_{\mathrm{p}-<2 \mathrm{~mm}}$ is equal to the $\rho_{\mathrm{p} \rightarrow 2 \mathrm{~mm}}$, the ratio of $\mathrm{SA}_{>2 \mathrm{~mm}} / \mathrm{SA}_{<2 \mathrm{~mm}}$ in Equation 6, simplifies to $\mathrm{r}_{<2 \mathrm{~mm}} / \mathrm{r}_{>2 \mathrm{~mm}}$. For this study, $\mathrm{r}_{<2 \mathrm{~mm}}$ was estimated by multiplying the percent clay, silt, and sand in each sediment by $1.025,0.026$ and $0.001 \mathrm{~mm}$, respectively, and then averaging these three numbers. $r_{>2 \mathrm{~mm}}$ were assumed to be $3 \mathrm{~mm}$.

\section{Natural Sediment Experiment}

Eight subsurface sediment samples were collected from the walls of a 20-m deep trench located in the 200 East Area of the Hanford Site, Richland, Washington. Samples were collected from sediment layers exposed by the trench to provide a wide range of gravel concentrations. At each sampling location, the surface $0.2-\mathrm{m}$ of sediment was discarded prior to collecting approximate $1-\mathrm{kg}$ sample. Samples were collected within $200 \mathrm{~m}$ of each other, in the same geologic formation and appeared to be composed of similar mineral assemblages. The samples were air-dried and then characterized for CEC, $\mathrm{pH}$, bulk density, and porosity. Strontium-sorption tests were conducted on total, $<2-\mathrm{mm}$, and $>2-\mathrm{mm}$ fractions following the General Sorption Procedure described above. There were four replicates for each gravelamendment and both controls. Gravel-corrected $\mathrm{K}_{\mathrm{d}}$ values were calculated using Equations 4 through 7.

\section{Gravel-Amended Experiment}

The solids used in these Sr-sorption experiment were composites created by combining varying amounts of gravel with the $<2-\mathrm{mm}$ sediment fraction from Sediment $F$ of the Natural Sediment Experiment. The composite samples contained $0,20,40,60,80$, and $100 \%(w t)$ gravel. The gravel used to make these samples was itself a composite of the gravel-fractions isolated from the sediments used in the Natural Sediment Experiment. The air-dried samples were characterized for CEC, $\mathrm{pH}$, bulk density, and porosity. Strontium-sorption tests were conducted on the entire composite sample following the General Sorption Procedure described above. There were four replicates of each gravel-amendment and both controls. Gravel-corrected $K_{d}$ values were calculated using Equations 4 through 7 . 


\section{Results and Discussion}

\section{Natural Sediment Experiment}

Selected physical and chemical properties of the sediments used in the Natural Sediment Experiment are presented in Table 2 . The gravel, sand, and silt-plus-clay $(<50 \mu \mathrm{m}$ fraction) fractions varied greatly between the sediments, ranging from 11.5 to $64.8 \%(w t)$ gravel, 35.1 to $88 \%$ sand, and 0.1 to $25 \%$ (wt) silt-plus-clay. Sediment $\mathrm{pH}$, porosity, and bulk density did not vary greatly; $\mathrm{pH}$ ranged by $<1 \mathrm{pH}$ unit, porosity by $<0.12-\mathrm{m}^{3} \mathrm{~m}^{-3}$, and bulk density by $280 \mathrm{~kg} \mathrm{~m}^{-3}$. There was no significant correlation $(\mathrm{P} \leq 0.05$ at 7 degrees of freedom) between gravel concentrations and CEC, porosity or bulk density. One would expect that as the gravel concentrations increased that bulk density would increase, and CEC and porosity would decrease. There was also no significant correlation between $\mathrm{pH}$ and CEC. There were significant differences between the bulk density and porosity values of the $<2-\mathrm{mm}$ and $>2-\mathrm{mm}$ fractions. The bulk density for the $<2-\mathrm{mm}$ fraction was always less than the bulk density for the whole sediment (except Sediment $\mathrm{H}$ ). The porosity for the $<2$ - $\mathrm{mm}$ fraction was always greater than the porosity for the whole sediment (again, except for Sediment $H$ ).

The various measured $K_{d}$ values and gravel-corrected $K_{d}$ values are presented in Table 3. Means and standard deviations for four replicates of the measured $K_{d}$ values, $K_{d t o t} K_{d<2 \mathrm{~mm}}$, and $K_{d>2 \mathrm{~mm}}$, are presented. No estimate of the variance associated with the gravel-corrected values is available because they had to be calculated from averaged $\mathrm{K}_{\mathrm{d}<2 \mathrm{~mm}}$ and gravel concentration $(f)$ values. All the gravel corrected $\mathrm{K}_{\mathrm{d}}$ values were significantly correlated to $\mathrm{K}_{\mathrm{dtot}}$, with $\mathrm{K}_{\mathrm{dgc}, 0=\mathrm{x}}$ and $\mathrm{K}_{\mathrm{d}<2 \mathrm{~mm}}$ having the largest correlation coefficients (Table 3). However, based on the percent difference with $\mathrm{K}_{\text {dtot }}$ (Equation 8), the accuracy of the various gravel-corrected $\mathrm{K}_{\mathrm{d}}$ values for estimating $\mathrm{K}_{\mathrm{dtot}}$ varied appreciably.

$$
\% \Delta K d_{x}=\left(\frac{K d_{x}-K d_{t o t}}{K d_{t o t}}\right) \times 100
$$

where $K_{d t o t}$ is the $K_{d}$ value measured using the entire sediment sample, $K_{d x}$ is a measured or gravelcorrected $K_{d}$ value (Equations $4-7$ ), and $\% \Delta K_{d x}$ is the percent difference between $K_{d x}$ and $K_{d t o t}$. On average, $\mathrm{K}_{\mathrm{d}<2 \mathrm{~mm}}$ was $28 \%$ greater than $\mathrm{K}_{\mathrm{dtot}}$, indicating that the $\mathrm{K}_{\mathrm{d}<2 \mathrm{~mm}}$ overestimated the $\mathrm{K}_{\mathrm{d}}$ of the entire sediment sample by $28 \%$ (Table 3 ). Conversely, $\mathrm{K}_{\triangleleft 2 \mathrm{~mm}}$ was on average $45 \%$ smaller than $\mathrm{K}_{\text {dtot. }}$ On average, $\mathrm{K}_{\mathrm{dgc}, g=0}$ underestimated $\mathrm{K}_{\text {dtot }}$ by $10 \%$, indicating that the $>2$-mm fraction had some sorptive capacity. This is not surprising in light of the fact that Hanford subsurface sediments typically contain iron-oxyhydroxide and carbonate coatings. Kaplan and Serne (1998) reported that three subsurface Hanford Site sediments contained about $0.3 \%$ (wt) $\mathrm{Fe}_{2} \mathrm{O}_{3}$ and $1.8 \% \mathrm{CaCO}_{3}$. These coatings may enhance the sorptive capacity of the feldspar, and quartz particles that typically comprise the larger particles of Hanford Site sediments. On average, $\mathrm{K}_{\mathrm{dgc}, \mathrm{g}=\mathrm{x}}$ overestimated $\mathrm{K}_{\mathrm{dtot}}$ by only $5 \%$. On average, $\mathrm{K}_{\mathrm{dgc}, \text { surf }}$ values underestimated $\mathrm{K}_{\text {dtot }}$ by $13 \%$.

The average ratio of $\mathrm{K}_{d>2 \mathrm{~mm}}$ to $\mathrm{K}_{\mathrm{d}<2 \mathrm{~mm}}$ for these sediments was $0.42 \pm 0.08$ (Table 3). Stated differently, the $\mathrm{K}_{\mathrm{d}}$ value of the gravel was $42 \%$ of the $\mathrm{K}_{\mathrm{d}}$ value of the $<2-\mathrm{mm}$ fraction. By using Equation 9, which assigns the $\mathrm{K}_{d>2 \mathrm{~mm}}$ a value 0.42 times $\mathrm{K}_{d<2 \mathrm{~mm}}$, it was possible to calculate precisely the average $\mathrm{K}_{\mathrm{dtot}}$ (Table 3). 


$$
K d_{g c, g=0.42}=(1-f) K d_{<2 m m}+(f) 0.42 K d_{<2 m m}
$$

Equation 9 provides the most accurate average gravel correction. Although Equation 8 requires only the knowledge of $f$ and $\mathrm{K}_{d<2 \mathrm{~mm}}$, it is limited insofar that the robustness of the 0.42 factor is not known. The 0.42 factor is likely not applicable to other contaminants or even to $\mathrm{Sr}$ in other sediment systems, since other sorption processes will often be involved.

Retardation factors were calculated (Equation 2) using the various measured and calculated $\mathrm{K}_{\mathrm{d}}$ values (Table 3). For these calculations, the porosity and bulk density values of the total sediment (Table 2) were used because these parameters are essentially always measured on the entire sediment sample, as opposed to the $<2-\mathrm{mm}$ sieved fraction used for the $\mathrm{K}_{\mathrm{d}}$ measurement. The $\mathrm{Rf}$ value for the sediments, $\mathrm{Rf}_{\text {tot, }}$ averaged $231 \pm 64$, meaning that $\mathrm{Sr}$ would be expected to move through these sediments at an average rate that was 231 times slower than water. The various $R f$ values varied proportionally to their respective $K_{d}$ values, since the difference between the two constructs is a scalar (i.e., the ratio of $\rho_{b} / \eta$ was constant for a given sediment). Thus, the $\%$ differences and correlation coefficients between the various $\mathrm{Rf}$ values and $\mathrm{Rf}_{\text {tot }}$ are identical to those listed in Table 3 for their respective $\mathrm{K}_{\mathrm{d}}$ values.

The relation between sediment properties and the various $\mathrm{K}_{d}$ values were evaluated through linear regression analyses and correlation coefficients (Table 4). As expected, gravel fraction ( $f$ ) and bulk density were generally inversely related to the various $\mathrm{K}_{\mathrm{d}}$ and $\% \Delta-\mathrm{K}_{\mathrm{d} x}$ values, whereas porosity and CEC were generally directly related to these parameters. Increases in gravel concentrations could decrease $\mathrm{Sr}$ $\mathrm{K}_{\mathrm{d}}$ values by a number of processes, including reducing the sediment surface area. Increases in bulk density would be expected to result in decreased $\mathrm{Sr} \mathrm{K}_{d}$ values because bulk density tends to increase in coarse sediments (Hillel 1980) and coarse sediments tend to have low specific surface areas (or low binding site concentrations) for Sr sorption. Conversely, increases in porosity would be expected to result in increased $\mathrm{Sr} \mathrm{K}_{\mathrm{d}}$ values because porosity tends to decrease in coarse sediments (Hillel 1980). The positive correlation coefficients with CEC may be attributed to the greater number of sorption sites available for Sr sorption.

\section{Gravel-Amended Experiment}

This experiment provided an estimate of the effect of gravel on sediment Sr- $\mathrm{K}_{d}$ values under more controlled conditions than in the Natural Sediment Experiment. In this experiment, the gravel fractions and the $<2-\mathrm{mm}$ fractions of each of the composite sediments had identical mineralogy; particle-size distributions, and surface chemistry. The only thing that changed between the samples was the proportion of the two size fractions.

The sediment properties used in the Gravel-Amended Experiment varied in an expected manner consistent with the amount of gravel added to the sediments (Table 4). As more gravel was added, the cation exchange capacity decreased $(r=-0.999, P \leq 0.001)$, porosity decreased $(r=-0.990, P \leq 0.001)$, and the bulk density increased $(\mathrm{r}=0.66, \mathrm{P} \leq 0.05)$. Unexplainably, $\mathrm{pH}$ also increased with increasing gravel additions $(\mathrm{r}=-0.991, \mathrm{P} \leq 0.001)$. 
$\mathrm{K}_{\mathrm{dgc}, \mathrm{g}=\mathrm{x}}$ estimates most closely reflected the measured $\mathrm{K}_{\mathrm{dtot}}$ values; overestimating the $\mathrm{K}_{\mathrm{dtot}}$ values on average by $3 \pm 3 \%$ (Equation 8 and Figure 1). $\mathrm{K}_{\text {dgc-surf }}$ underestimated $\mathrm{K}_{\text {dtot }}$ values on average by $-33 \% \pm$ $32 \%$, the degree of underestimation increased as the amount of gravel added increased. Similarly, $\mathrm{K}_{\mathrm{dgc}, g=0}$ underestimated $\mathrm{K}_{\text {dtot }}$ values on average by $-39 \pm 37 \%$, the degree of underestimation also increased as the amount of gravel added increased. A ranking of the $\mathrm{K}_{d}$ values by percent difference with $\mathrm{K}_{\mathrm{dtot}}$, i.e., by their overall accuracy in estimate $\mathrm{K}_{\mathrm{dtot}}$ is consistent with the ranking for the Natural Sediment Experiment (Figure 2): $\mathrm{K}_{\mathrm{d}<2 \mathrm{~mm}}>\mathrm{K}_{\mathrm{dgc}, g=\mathrm{x}}>\mathrm{K}_{\mathrm{dtot}}>\mathrm{K}_{\mathrm{dgc}, \mathrm{g}=0} \geq \mathrm{K}_{\mathrm{dgc}, \text { surf }}>\mathrm{K}_{\mathrm{d}>2 \mathrm{~mm}}$. For this experiment, $\mathrm{K}_{\mathrm{d}>2 \mathrm{~mm}}$ was $15.2 \mathrm{~L}$ $\mathrm{kg}^{-1}$ and $\mathrm{K}_{\mathrm{d}<2 \mathrm{~mm}}$ was $29.5 \mathrm{~L} \mathrm{~kg}^{-1}$ (Figure 1). The $\mathrm{K}_{\mathrm{d}>2 \mathrm{~mm}} / \mathrm{K}_{\mathrm{d}<2 \mathrm{~mm}}$ was 0.52 , compared to the average ratio in the Natural Sediment Experiment of 0.42 (Table 3).

Strontium retardation factors calculated with $\mathrm{K}_{\text {drot }}$ values (Equation 2) varied from 235 for the $<2-\mathrm{mm}$ fraction treatment ( $0 \%$ gravel-added sediments in Figure 2) to 166 for the gravel amended (100\% graveladded sediments in Figure 2$)$. $R f\left(K_{d g c, g=x}\right)$ values estimated actual $R f$ values, $R f\left(K_{d t o t}\right)$, very closely. $R f\left(K_{d<2 m m}\right)$ overestimated and $R f\left(K_{d g c, s u r f}\right)$ and $R f\left(K_{d g c, g=0}\right)$ underestimated $R f\left(K_{d t o t}\right)$. All of these trends are consistent with those observed for the respective $K_{d}$ values (Figure 1). Unlike the other $R f$ values, $R f\left(K_{d<2 \mathrm{~mm}}\right)$ values increased as the percent of added gravel increased. Since the value of $\mathrm{K}_{\mathrm{d}<2 \mathrm{~mm}}$ used to calculate $R f\left(K_{d<} 2 \mathrm{~mm}\right)$ remained constant for the various added-gravel treatments, the increase in $R f$ values reflects changes in the ratio of bulk density to porosity (Equation 2). The bulk density to porosity ratio varied from 7.84 to 11.37 as the percent of added gravel increased from 0 to $100 \%$ (Table 5). This is an increase of $45 \%$ with respect to the ratio of the $0 \%$ added-gravel treatment. Since an increase in $\mathrm{Rf}$ is not expected as more gravel is added to a system, this illustrates an intrinsic error with keeping the $\mathrm{K}_{\mathrm{d}}$ constant while varying the bulk density and porosity values. Since bulk density and porosity are more easily measured or estimated by empirical relations, it is not improbable that a modeled system would make this error.

\section{Conclusions}

Two experiments were conducted to quantify the gravel- $\mathrm{K}_{d}$ issue. Additionally, these experiments sought to evaluate methods an empirical method or formula to permit the conversion of the $K_{d<2 \mathrm{~mm}}$ value traditionally collected from laboratory experiments to gravel-corrected $\mathrm{K}_{d}$ values. The worse estimate of the actual $\mathrm{K}_{\mathrm{d}}$ and $\mathrm{Rf}$ values for gravel-containing sediments was the traditional $\mathrm{K}_{\mathrm{d}<2 \mathrm{~mm}}$. On average, $\mathrm{K}_{\mathrm{d}<2 \mathrm{~mm}}$ over estimated actual $\mathrm{K}_{d}$ values by $28 \%$ in the Natural Sediment Experiment and $47 \%$ in the GravelAdded Experiment. In one experiment, $\mathrm{Rf}\left(\mathrm{K}_{d<2 \mathrm{~mm}}\right)$ values actually increased as the actual $\mathrm{Rf}$ values decreased. Of the various gravel-corrected $K_{d}$ values, $K_{d g c, g=x}$ provided the best estimate of the actual $K_{d}$ value, $\mathrm{K}_{\mathrm{dtot}}$, slightly overestimating $\mathrm{K}_{\mathrm{dtot}}$ values on average by between 3 and $5 \%$. In both experiments, $\mathrm{K}_{\mathrm{dgc}-\mathrm{x}=0}$ and $\mathrm{K}_{\mathrm{dgc}, \text { surf }}$ underestimated actual $\mathrm{K}_{\mathrm{d}}$ values, the disparity systematically increased as the amount of gravel in the sample increased. This suggests that the gravel corrections for both constructs are less than perfect and therefore become systematically worse as the amount of gravel in the sample increases.

Although $\mathrm{K}_{\mathrm{dgc}, \mathrm{g}=\mathrm{x}}$ clearly provided the best estimate of the actual $\mathrm{K}_{\mathrm{d}}$ value, it has the important disadvantage in that it requires knowledge of the $\mathrm{K}_{d}$ value for the $>2 \mathrm{~mm}$ fraction. This is experimentally difficult to measure and requires additional resources to acquire. When this information can not be acquired, the $\mathrm{K}_{\mathrm{dgc}, \mathrm{g}=0}$ or $\mathrm{K}_{\mathrm{dgc}, \text { surf }}$ constructs may be a reasonable alternative. $\mathrm{K}_{\mathrm{dgc}, \mathrm{g}=0}$ has the advantage over $\mathrm{K}_{\mathrm{dgc}, \text { surf }}$ in that the former requires knowledge of the percent gravel, whereas the latter requires knowledge of percent 
gravel and mean particle sizes in the $<2-\mathrm{mm}$ and $>2-\mathrm{mm}$ fractions. Percent gravel in a sediment may be inexpensively acquired by sieve analysis or if need be, estimated from common stratigraphic descriptions of well boreholes.

The findings in this study have important implications regarding the traditional approach to modeling contaminant transport using $\mathrm{K}_{\mathrm{d}<2 \mathrm{~mm}}$ values because such modeling may overestimate the ability of gravelcontaining sediments to retard contaminant migration. This is a problem insofar that lower-bounding estimates, that is, conservative estimates, of contaminant migration may not be in fact truly lowerbounding and therefore worse-case scenarios may be improperly estimated. Use of gravel-corrected $\mathrm{K}_{\mathrm{d}}$ values will improve such lower-bounding estimates.

\section{Acknowledgements}

The work in this manuscript was funded by the Hanford Immobilized Low-Activity Waste Performance Assessment Project. The Westinghouse Savannah River Company is operated for the U.S. Department of Energy under contract DE-AC09-89SR-18035. The Pacific Northwest National Laboratory is operated by Battelle Memorial Institute for the U.S. Department of Energy under Contract DE-AC06-76RLO1830. The authors thank Dr. Gary Iversen (SCUREF, Columbia SC) and Dr. Steven M. Serkiz (WSRC, Aiken, SC) for reviewing an earlier version of this manuscript.

\section{References}

Allison, J. D., D. S. Brown, and K. J. Novo-Gradac. 1991. MINTEQA2/PRODEFA2, A Geochemical Assessment Model for Environmental Systems: Version 3.0 User's Manual. U.S. Environmental Protection Agency, Athens, GA. EPA/600/3-91/021.

Ames, L. L., and D. Rai. 1978. Radionuclide interactions with rock and soil media. Volume I. U.S. Environmental Protection Agency, Office of Radiation Programs, Las Vegas, NV. PB292360.

Bower, H. 1991. Simple derivation of the retardation equation and application to preferential flow and macrodispersion. Ground Water. v. 29, pp. 41-46.

Gee, G. W., and J. W. Bauder. 1986. Particle-size analysis. In: Methods of Soil Analysis, Part 1. A. Klute, ed. American Society of Agronomy, Inc. Publisher, Madison, WI. pp. 383-412.

Hillel, D. 1980. Fundamentals of Soil Physics. Academic Press, New York. 413 pp.

Kaplan, D. I., K. M. Krupka, R. J. Serne, S. V. Mattigod, and G. Whelan. 1998. Selection of distribution coefficients for contaminant fate and transport calculations. 1997 International Containment Technology Conference and Exhibition. Fort Lauderdale, FL. pp. 954-960.

Kaplan, D. I., and R. J. Serne. 1998. Pertechnetate exclusion from sediments. Radiochimica Acta. v. 81, pp.117-124. 
Klute, A., and C. Dirksen. 1996. Hydraulic Conductivity and Diffusivity: Laboratory Methods. In: Methods of Soil Analysis, Part 1. A. Klute, ed. American Society of Agronomy, Inc. Publisher, Madison, WI. pp. 687-734.

McLean, W. O. 1987. Soil pH and Lime Requirement. In: Methods of Soil Analysis, Part 2. A. L. Page, R. H. Miller, and D. R. Keeney, eds. American Society of Agronomy, Inc. Publisher, Madison, WI. pp. 199- 224.

Nelson, R. E. 1987. Carbonate and gypsum. In: Methods of Soil Analysis, Part 2. A. L. Page, R. H. Miller, and D. R. Keeney, eds. American Society of Agronomy, Inc. Publisher, Madison, WI. pp. 181198.

Rhodes, J. K. 1987. Cation Exchange Capacity. In: Methods of Soil Analysis, Part 2. A. L. Page, R. H. Miller, and D. R. Keeney, eds. American Society of Agronomy, Inc. Publisher, Madison, WI. pp. 149158

Sposito, G. 1984. Surface Chemistry of Soils. Oxford University Press, New York. 234 pp.

Thibault, D. H., M. I. Sheppard, and P. A. Smith. 1990. A critical compilation and review of default soil solid/liquid partition coefficients, $\mathrm{K}_{\mathrm{d}}$, for use in environmental assessments. Whiteshell Nuclear Research Establishment, Pinawa, Manitoba, Canada. AECL-10125. 112 pp.

Valocchi, A. J. 1984. Describing the transport of ion-exchange contaminants using an effective $\mathrm{K}_{\mathrm{d}}$ approach. Water Resources Research. v. 20, pp. 499-503. 
Table 1. Ground water $(<0.45-\mu \mathrm{m}$ Filter $)$ Chemical Composition

\begin{tabular}{|c|c|}
\hline Constituent & Concentration $\left(m g L^{-1}\right)$ \\
\hline$\overline{\mathrm{pH}}$ & 8.3 (unitless) \\
\hline $\mathrm{Cl}^{-}$ & 22 \\
\hline $\mathrm{NO}_{3}^{-}$ & 1.7 \\
\hline $\mathrm{SO}_{4}^{-2}$ & 108 \\
\hline Total Organic C & 0.73 \\
\hline Total Alkalinity (as $\mathrm{CO}_{3}{ }^{2-}$ ) & 67.5 \\
\hline $\mathrm{Al}$ & 0.14 \\
\hline B & 0.05 \\
\hline $\mathrm{Ba}$ & 0.069 \\
\hline $\mathrm{Ca}$ & 67.5 \\
\hline $\mathrm{Fe}$ & 0.14 \\
\hline $\mathrm{K}$ & 3 \\
\hline $\mathrm{Mg}$ & 16.4 \\
\hline $\mathrm{Mn}$ & 0.046 \\
\hline $\mathrm{Na}$ & 27.6 \\
\hline $\mathrm{Si}$ & 16.2 \\
\hline $\mathrm{Sr}$ & 0.28 \\
\hline Sum of Cations ${ }^{\mathrm{a}}$ & $0.0065 \mathrm{M}$ \\
\hline Sum of Anions ${ }^{a}$ & $0.0054 \mathrm{M}$ \\
\hline Equilibrium Ionic Strength ${ }^{a}$ & 0.00918 \\
\hline
\end{tabular}

${ }^{\text {a Calculated by the geochemical thermodynamic code MINTEQA2 (Allison et }}$ al. 1991).

Table 2. Properties of Sediments Used in the Natural Sediment Experiment

\begin{tabular}{|c|c|c|c|c|c|c|c|c|c|}
\hline \multirow[b]{2}{*}{$\begin{array}{l}\text { Sediment } \\
\text { Code }\end{array}$} & \multicolumn{5}{|l|}{ Total Sediment } & \multicolumn{3}{|c|}{$<2-m m$ Fraction } & \multirow{2}{*}{$\begin{array}{l}2-m m \\
\text { Fraction } \\
C E C \\
\left(\text { meq } \mathrm{kg}^{-1}\right)\end{array}$} \\
\hline & $\begin{array}{l}\text { Gravel/Sand/ } \\
\text { Silt }+ \text { Clay } \\
(w t . \%)^{a}\end{array}$ & $p H$ & $\begin{array}{l}\text { Bulk } \\
\text { Density } \\
\left(\mathrm{kg} \mathrm{m}^{-3}\right)\end{array}$ & $\begin{array}{l}\text { Porosity } \\
\left(\mathrm{m}^{3} \mathrm{~m}^{-3}\right)\end{array}$ & $\begin{array}{l}C E C \\
\left(\text { meq } k^{-1}\right)\end{array}$ & $\begin{array}{l}\text { Bulk } \\
\text { Density } \\
\left(\mathrm{kg} \mathrm{m}^{-3}\right)\end{array}$ & $\begin{array}{l}\text { Porosity } \\
\left(m^{3} m^{-3}\right)\end{array}$ & $\begin{array}{l}C E C \\
\left(m e q k^{-1}\right)\end{array}$ & \\
\hline$\overline{\mathrm{A}}$ & $11.5 / 88.0 / 0.5$ & 8.34 & 1900 & 0.30 & 46.7 & 1860 & 0.31 & 59.2 & 26.2 \\
\hline B & $39.0 / 54.0 / 7.0$ & 9.01 & 2140 & 0.22 & 22.6 & 1840 & 0.28 & 16.8 & 16.9 \\
\hline C & $28.0 / 69.5 / 2.5$ & 9.03 & 2000 & 0.21 & 22.3 & 1820 & 0.26 & 14.5 & 6.1 \\
\hline $\mathrm{D}$ & $44.0 / 55.6 / 0.4$ & 9.25 & 2100 & 0.22 & 20.0 & 1840 & 0.30 & 13.1 & 18.2 \\
\hline$E$ & $44.0 / 53.7 / 2.3$ & 9.02 & 2030 & 0.19 & 15.5 & 1800 & 0.27 & 16.7 & 6.0 \\
\hline $\mathrm{F}$ & $21.0 / 54.0 / 25.0$ & 8.38 & 2030 & 0.24 & 23.5 & 1960 & 0.25 & 19.1 & 6.0 \\
\hline G & $52.0 / 43.0 / 5.0$ & 9.18 & 2180 & 0.20 & 19.6 & 1700 & 0.27 & 17.0 & NA \\
\hline $\mathrm{H}$ & $64.8 / 35.1 / 0.1$ & 8.20 & 1930 & 0.31 & 73.0 & 1810 & 0.31 & 81.0 & 19.0 \\
\hline
\end{tabular}

${ }^{2}$ Gravel is $\geq 2-\mathrm{mm}$; Sand is $<2-\mathrm{mm}$ and $\geq 50-\mu \mathrm{m}$; Silt + Clay is $<50-\mu \mathrm{m}$. 
Table 3. Sr $\mathrm{K}_{\mathrm{d}}$ Values, Retardation Factors and Correlation Coefficients from the Natural Sediment Experiment

\begin{tabular}{llllllll}
\hline & $\mathrm{K}_{\mathrm{d} f o t}$ & $\mathrm{~K}_{\mathrm{d}<2 m m}$ & $\mathrm{~K}_{\mathrm{d}>2 m m}$ & $\mathrm{~K}_{\mathrm{dgc}, g=x}{ }^{a}$ & $\mathrm{~K}_{\mathrm{dgc}, g=0}{ }^{a}$ & $\mathrm{~K}_{\mathrm{dgc}, s u f f^{a}}$ & $\mathrm{~K}_{\mathrm{d} g c, x=0.42^{a}}$ \\
\hline Sediment A & $38 \pm 3$ & $50 \pm 2$ & $22 \pm 1$ & 47 & 44 & 45 & 47 \\
Sediment B & $37 \pm 4$ & $51 \pm 3$ & $20 \pm 1$ & 39 & 31 & 34 & 39 \\
Sediment C & $20 \pm 4$ & $34 \pm 1$ & $12 \pm 4$ & 28 & 24 & 25 & 28 \\
Sediment D & $19 \pm 3$ & $23 \pm 0$ & $13 \pm 1$ & 19 & 13 & 14 & 17 \\
Sediment E & $18 \pm 3$ & $21 \pm 1$ & $10 \pm 1$ & 16 & 12 & 13 & 15 \\
Sediment F & $31 \pm 4$ & $33 \pm 3$ & $13 \pm 3$ & 29 & 26 & 27 & 29 \\
Sediment G & $23 \pm 3$ & $27 \pm 1$ & $13 \pm 6$ & 20 & 13 & 15 & 19 \\
Sediment H & $27 \pm 2$ & $31 \pm 1$ & $10 \pm 2$ & 27 & 31 & 15 & 19 \\
Avg. $\mathrm{K}_{\mathrm{d}}$ & $27 \pm 8$ & $34 \pm 11$ & $14 \pm 4$ & $28 \pm 11$ & $24 \pm 11$ & $24 \pm 11$ & $27 \pm 11$ \\
Avg. \% $\Delta-\mathrm{K}_{\mathrm{dtot}}{ }^{b}$ & 0 & $28 \pm 21$ & $-45 \pm 10$ & $5 \pm 19$ & $-10 \pm 27$ & $-13 \pm 25$ & $0 \pm 24$ \\
Corr. Coef. with $\mathrm{K}_{\text {dtot }}{ }^{\mathrm{c}}$ & 1.00 & $0.91 *$ & 0.83 & $0.91 *$ & 0.85 & $0.78^{*}$ & 0.87 \\
Avg Rf & $231 \pm 64$ & $296 \pm 96$ & $126 \pm 38$ & $241 \pm 74$ & $204 \pm 70$ & $203 \pm 81$ & $231 \pm 86$ \\
\hline
\end{tabular}

${ }^{a}$ Equations 4 through 7 and 9 were used to calculate these $K_{d}$ values.

${ }^{\mathrm{b}}$ Equation 8 was used to calculate $\% \Delta-\mathrm{K}_{\mathrm{dtot}}$.

${ }^{c}$ Correlation coefficients between the various $\mathrm{K}_{\mathrm{d}}$ constructs and $\mathrm{K}_{\text {dtot. }}{ }^{*}$, , and * indicate significance at the 5\% level $(\mathrm{P} \leq 0.05), 1 \%$ level $(\mathrm{P} \leq 0.01)$, and $0.1 \%$ level $(\mathrm{P} \leq 0.01)$, respectively, for 7 degrees of freedom.

${ }^{d}$ Retardation factors were calculated using Equation $2, \mathrm{~K}_{\mathrm{d}}$ values from this table, and porosity and bulk density of the entire sediment from Table 2.

Table 4. Correlation Coefficients Between $\mathrm{Sr} \mathrm{K}_{\mathrm{d}}$ Values and Sediment Properties for the Natural Sediment Experiment

\begin{tabular}{|c|c|c|c|c|}
\hline & Gravel Fraction $(f)$ & $\begin{array}{l}\text { Bulk Density of } \\
\text { Entire Sediment }\end{array}$ & $\begin{array}{l}\text { Porosity of Entire } \\
\text { Sediment }\end{array}$ & $\begin{array}{l}\text { CEC of Entire } \\
\text { Sediment }\end{array}$ \\
\hline$\overline{K_{\text {dtot }}}$ & -0.46 & -0.23 & 0.56 & 0.35 \\
\hline $\mathrm{K}_{\mathrm{d}<2 \mathrm{mmm}}$ & -0.51 & -0.22 & 0.44 & 0.26 \\
\hline $\mathrm{K}_{\mathrm{d}>2 \mathrm{~mm}}$ & $-0.59 * \mathrm{a}$ & -0.06 & 0.31 & 0.04 \\
\hline $\mathrm{K}_{\mathrm{dgc}, \mathrm{g}=\mathrm{x}}$ & $-0.61 *$ & -0.42 & $0.59^{*}$ & 0.37 \\
\hline $\mathrm{K}_{\mathrm{dgc}, \mathrm{g}=0}$ & -0.48 & $-0.64^{*}$ & 0.79 & $0.63^{*}$ \\
\hline $\mathrm{K}_{\mathrm{dgc}, \text { surf }}$ & -0.79 & -0.36 & 0.42 & 0.14 \\
\hline$\% \Delta-K_{d<2 m m}{ }^{b}$ & -0.28 & -0.08 & -0.15 & -0.13 \\
\hline$\% \Delta-\mathrm{K}_{\mathrm{d}>2 \mathrm{~mm}}$ & -0.21 & 0.32 & -0.47 & -0.56 \\
\hline$\% \Delta-\mathrm{K}_{\mathrm{dgc}, \mathrm{g}=\mathrm{x}}$ & -0.51 & -0.47 & 0.23 & 0.15 \\
\hline$\% \Delta-\mathrm{K}_{\mathrm{dgc}, \mathrm{g}=0}$ & -0.31 & $-0.78^{*}$ & $0.67^{*}$ & $0.64^{*}$ \\
\hline$\% \Delta-\mathrm{K}_{\mathrm{dgc}, \text { surf }}$ & -0.81 & -0.33 & 0.03 & -0.16 \\
\hline
\end{tabular}


Table 5. Properties of Sediments Used in the Gravel-Amended Sediment Experiment

\begin{tabular}{lllll}
\hline $\begin{array}{l}\text { Gravel Added } \\
(\%, w t)\end{array}$ & $\begin{array}{l}\text { CEC } \\
\left(\mathrm{meq} \mathrm{kg}^{-1}\right)\end{array}$ & $p H$ & $\begin{array}{c}\text { Bulk Density } \\
\left(\mathrm{kg} \mathrm{m}^{-3}\right)\end{array}$ & $\begin{array}{l}\text { Porosity } \\
\left(\mathrm{m}^{3} \mathrm{~m}^{-3}\right)\end{array}$ \\
\hline 0 & 140.3 & 8.38 & 1960 & 0.25 \\
20 & 118.2 & 8.44 & 1980 & 0.24 \\
40 & 95.9 & 8.52 & 2010 & 0.23 \\
60 & 73.3 & 8.61 & 2050 & 0.22 \\
80 & 51.6 & 8.67 & 2100 & 0.21 \\
100 & 29.5 & 8.7 & 2160 & 0.19 \\
\hline
\end{tabular}




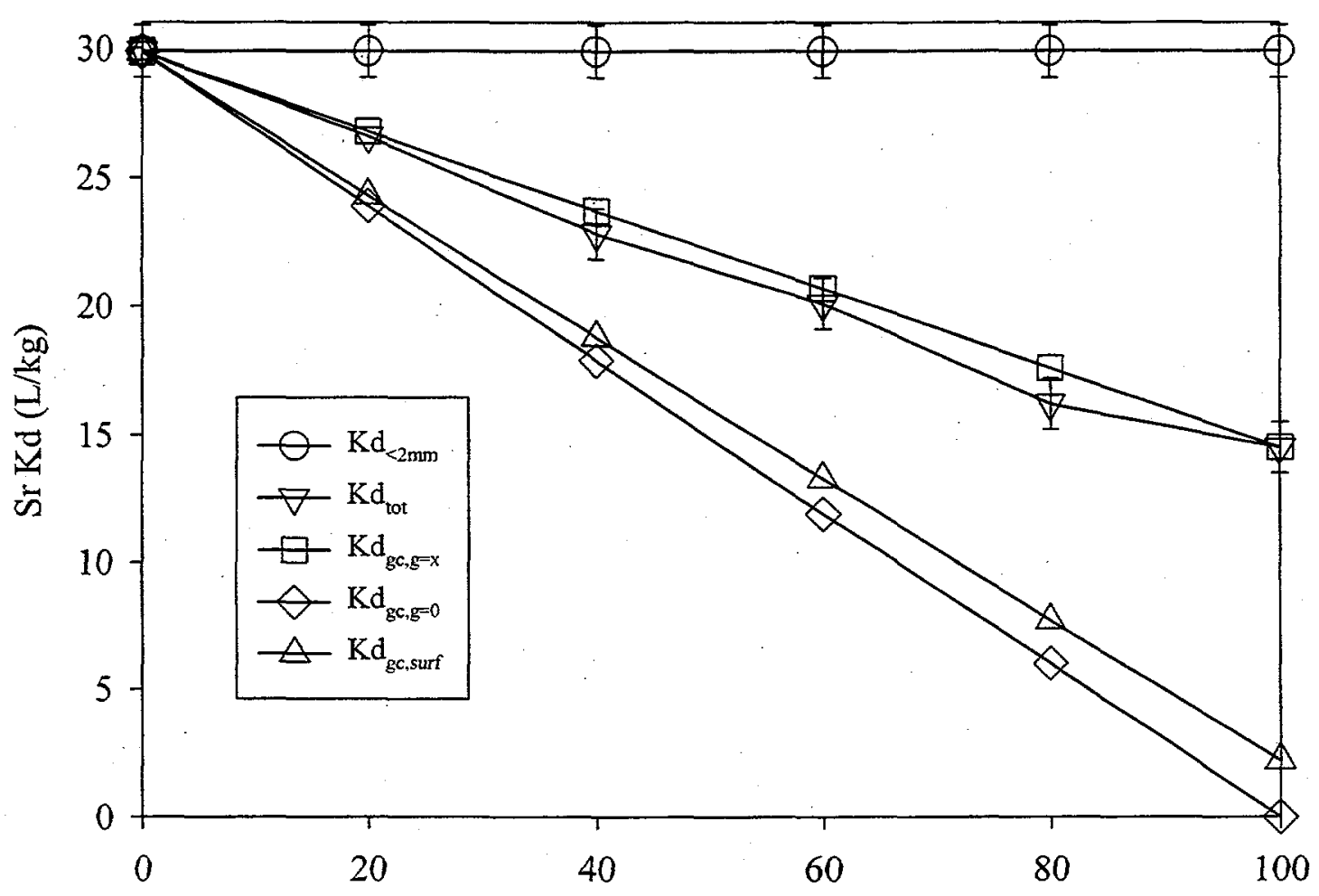

Figure 1. Measured and gravel-corrected $\mathrm{Sr} \mathrm{K}_{\mathrm{d}}$ Values from the Gravel-Amended Experiment. $\mathrm{K}_{\mathrm{d}<2 \mathrm{~mm}}$ is . $29.9 \mathrm{~L} \mathrm{~kg}^{-1} ; \mathrm{K}_{\mathrm{d}>2 \mathrm{~mm}}$ is $15 \mathrm{~L} \mathrm{~kg}^{-1} . \mathrm{K}_{\text {dtot }}$ is the mean and standard deviation of 4 replicates. $\mathrm{K}_{\mathrm{dgc}, \mathrm{g}=0,0}, \mathrm{~K}_{\mathrm{dgc}, \mathrm{g}=\mathrm{x}}$, and $\mathrm{K}_{\mathrm{dgc} \text {,surf }}$ calculated from Equations 4,5 , and 6, respectively. 


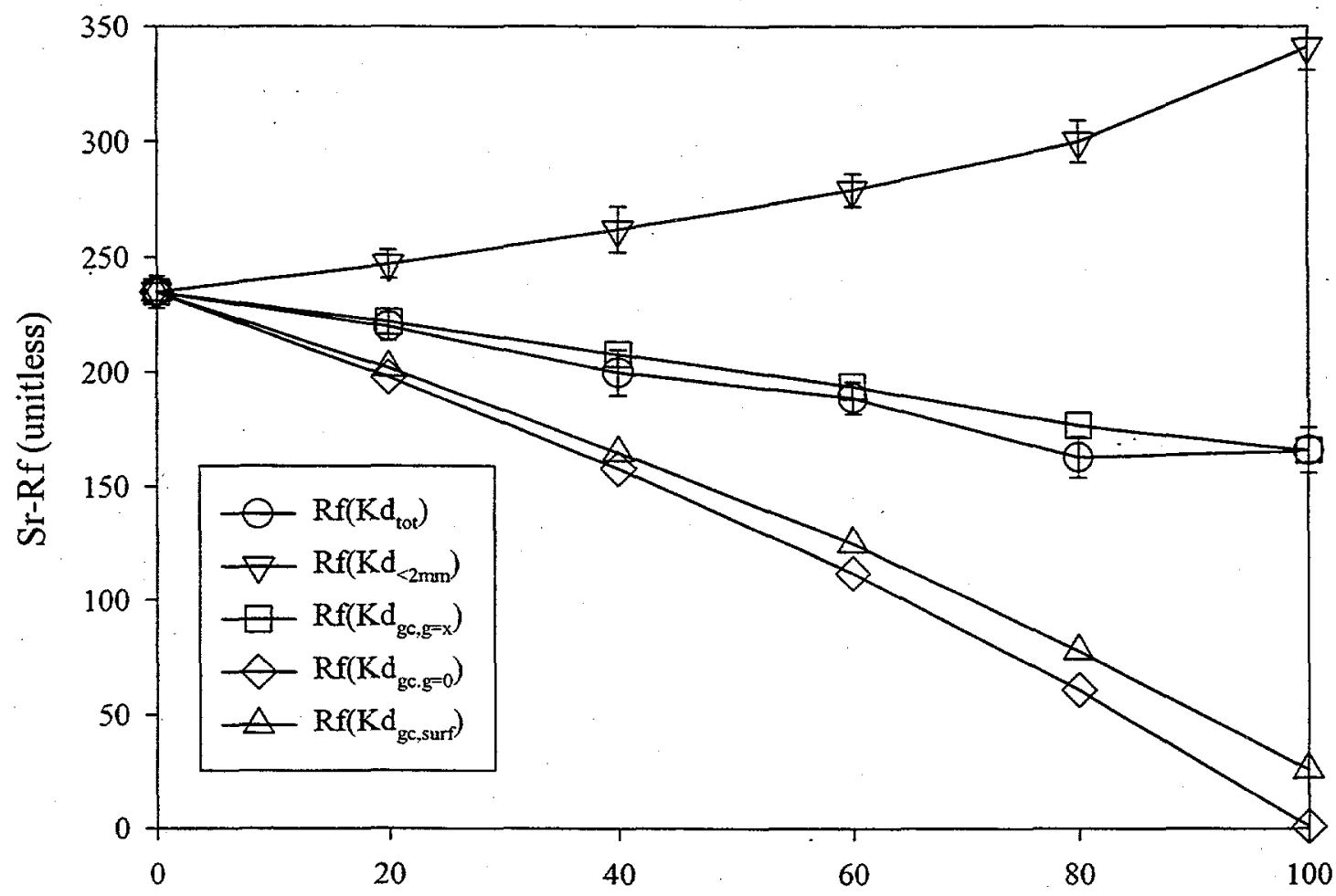

Figure 2. Strontium retardation factors $(\mathrm{Rf})$ as a function of added gravel. $\mathrm{Rf}$ values calculated with $\mathrm{K}_{\text {dtot, }}$ $\mathrm{K}_{\mathrm{d}<2 \mathrm{~mm}}, \mathrm{~K}_{\mathrm{dgc}, \mathrm{g}=0}$ (Equation 4), $\mathrm{K}_{\mathrm{dgc}, \mathrm{g}=\mathrm{x}}$ (Equation 5), and $\mathrm{K}_{\mathrm{dgc}, \text { surf }}$ (Equation 6), and measured bulk density and porosity values (Table 4). $\operatorname{Rf}\left(\mathrm{K}_{\mathrm{dtot}}\right)$ is the mean and standard deviation of 4 replicates. $\mathrm{Rf}$ values from gravel-corrected $\mathrm{K}_{\mathrm{d}}$ values were calculated using means, therefore no measure of variability is available. 
Appendix B

$K_{d}$ Values for Far-Field Sediment Conditions 


\section{Appendix B}

\section{$K_{d}$ Values for Far-Field Sediment Conditions ${ }^{(a)}$}

\begin{tabular}{|c|c|c|c|c|}
\hline $\begin{array}{l}\text { Radio- } \\
\text { nuclide }\end{array}$ & $\begin{array}{l}\text { Reasonably } \\
\text { Conservative } \\
\mathrm{K}_{\mathrm{d}}(\mathrm{mL} / \mathrm{g}) \\
\end{array}$ & $\begin{array}{l}\text { "Best" } K_{d} \\
(\mathrm{~mL} / \mathrm{g})\end{array}$ & $\begin{array}{l}\mathrm{K}_{\mathrm{d}} \text { Range } \\
(\mathrm{mL} / \mathrm{g})\end{array}$ & Justification/References $^{(b)}$ \\
\hline $\begin{array}{l}{ }^{3} \mathrm{H}, \mathrm{Cl}, \\
\mathrm{Tc}\end{array}$ & 0 & 0 & 0 to 0.6 & $\begin{array}{l}\text { Tc exists predominantly as } \mathrm{TcO}_{4}^{-} \text {. A review of Hanford sediment Tc- } \mathrm{K}_{\mathrm{d}} \text { values showed a range of }-2.8 \\
\text { to } 0.6 \mathrm{~mL} / \mathrm{g} \text { for } 15 \text { observations; median was } 0.1 \mathrm{~mL} / \mathrm{g}(1) \text {. Later studies did not change this range but } \\
\text { did decrease the median slightly to }-0.1 \mathrm{~mL} / \mathrm{g}(2) \text {. Negative } \mathrm{K}_{\mathrm{d}} \text { values are physically possible and may } \\
\text { not be an experimental artifact (2). }{ }^{3} \mathrm{H} \text { is expected to move along with water. } \mathrm{Cl} \text { is expected to behave } \\
\text { as a dissolved anionic species. Most recent results using ILAW specific borehole sediments [299-E17- } \\
\text { 21] yielded Tc- } \mathrm{K}_{\mathrm{d}} \text { of } 0 \mathrm{~mL} / \mathrm{g} \text {. See Kaplan et al. (18) for details. }\end{array}$ \\
\hline $\begin{array}{l}\text { Ac, } \mathrm{Am}, \\
\mathrm{Ce}, \mathrm{Cm}, \\
\mathrm{Eu}\end{array}$ & 60 & 300 & 60 to 1300 & $A m-K_{d}: 67$ to $>1200 \mathrm{~mL} / \mathrm{g}(3) . A m-K_{d}: 125$ to $833 \mathrm{~mL} / \mathrm{g} \mathrm{(4)}$ \\
\hline C & 0.5 & 5 & 0.5 to 1000 & $\begin{array}{l}\text { Assumed dominant species: } \mathrm{HCO}_{3} \text {. Three processes will be acting on the }{ }^{14} \mathrm{C} \text { to take it out of solution: } \\
\text { adsorption onto the calcite surface, volatilization as } \mathrm{CO}_{2} \text { gas, and precipitation into the calcite structure. } \\
\text { The latter process is largely irreversible, therefore it is not well represented by the } \mathrm{K}_{\mathrm{d}} \text { construct }\left(\mathrm{K}_{\mathrm{d}}\right. \\
\text { assumes that adsorption occurs as readily as desorption). Volatilization is entirely removed from the } \\
\text { definition of the } \mathrm{K}_{\mathrm{d}} \text { construct. In systems that contain higher concentrations of carbonate minerals, such } \\
\text { as the calcrete layer in the } 200 \text { West Area, an appreciably higher } \mathrm{K}_{\mathrm{d}} \text { should be used to account for the } \\
\text { isotopic dilution/precipitation reaction that may occut. A } \mathrm{K}_{\mathrm{d}} \text { of } 100 \mathrm{~mL} / \mathrm{g} \text { would be appropriate for such } \\
\text { a system. Since most of the } 100 \text { and } 200 \text { plateau areas contain }<1 \% \text { carbonate, lower } \mathrm{K}_{\mathrm{d}} \text { values are } \\
\text { warranted for these areas, such as } 0.5 \mathrm{~mL} / \mathrm{g} \text {. } \mathrm{K}_{\mathrm{d}} \text { values of }{ }^{14} \mathrm{C} \text { of }>250 \mathrm{~mL} / \mathrm{g} \text { have been measured in } \\
\text { calcite (5). At } 100 \mathrm{~K} \text {, the C-14 is widely distributed down gradient from a major source (crib) associated } \\
\text { with reactor operations. (Additional references: } 6,7,8,9,10) \text {. Estimated range. }\end{array}$ \\
\hline$\overline{\mathrm{Co}}$ & 1000 & 2000 & $\begin{array}{l}1000 \text { to } \\
12500\end{array}$ & $\begin{array}{l}\text { Na system, } 1290 \text { to } 2120 \mathrm{~mL} / \mathrm{g} \mathrm{(11)} \\
\text { Ca system, } 2000 \text { to } 3870 \mathrm{~mL} / \mathrm{g} \mathrm{(11)} \\
\text { Hanford sediment/groundwater system } 11600 \text { to } 12500 \mathrm{~mL} / \mathrm{g} \mathrm{(12)}\end{array}$ \\
\hline Cs & 500 & 2000 & \begin{tabular}{|l|}
500 to \\
4000
\end{tabular} & $\begin{array}{l}\mathrm{Na} \text { system, } 1410 \text { to } 1590 \mathrm{~mL} / \mathrm{g}(11) \\
\text { Hanford sediment/groundwater system, } 540 \text { to } 3180 \mathrm{~mL} / \mathrm{g}(12) \text {. Most recent results using ILAW } \\
\text { specific borehole sediments [299-E17-21] yielded } \mathrm{K}_{\mathrm{d}} \text { of } 2,030 \pm 597 \text {. See Kaplan et al. (18) for details. }\end{array}$ \\
\hline
\end{tabular}




\begin{tabular}{|c|c|c|c|c|}
\hline $\mathrm{I}$ & 0 & 0.1 & 0.0 to 15 & $\begin{array}{l}\text { A review of Hanford sediment I- } \mathrm{K}_{\mathrm{d}} \text { values showed a range of } 0.7 \text { to } 15 \mathrm{~mL} / \mathrm{g} \text { for } 9 \text { observations; median } \\
\text { was } 0.7 \mathrm{~mL} / \mathrm{g}(1) \text {. Later studies increased this range to } 0.2 \text { to } 15 \mathrm{~mL} / \mathrm{g} \text {; the median was decreased to } 0.3 \\
\mathrm{~mL} / \mathrm{g}(2) \text {. Most recent results using ILAW specific borehole sediments [299-E17-21] yielded } \mathrm{K}_{\mathrm{d}} \text { of } 0 \\
\mathrm{~mL} / \mathrm{g}(18) \text {. }\end{array}$ \\
\hline $\begin{array}{l}\mathrm{Ni}, \mathrm{Sn}, \\
\mathrm{Nb}\end{array}$ & 50 & 300 & 50 to 2500 & $\begin{array}{l}\mathrm{Ni} \text { : Hanford sediment/groundwater system, } 440 \text { to } 2350 \mathrm{~mL} / \mathrm{g}(12) \\
\mathrm{Ni} \text { : A study of a broad range of sediments, including those from Hanford had Ni- } \mathrm{K}_{\mathrm{d}} \mathrm{s} \text { of } 50 \text { to } 340 \mathrm{~mL} / \mathrm{g} \\
\text { (13). }\end{array}$ \\
\hline$\overline{\mathrm{Np}}$ & 2 & 15 & 2 to 25 & $\begin{array}{l}\text { A review of Hanford sediment } \mathrm{Np}-\mathrm{K}_{\mathrm{d}} \text { values showed range of } 2.4 \text { to } 21.7 \mathrm{~mL} / \mathrm{g} \text { for } 4 \text { observations; } \\
\text { median was } 17.8 \mathrm{~mL} / \mathrm{g}(1) . \text { Later studies increased the slightly to } 2.2 \text { to } 21.7 \mathrm{~mL} / \mathrm{g} \text {; the median was } \\
\text { slightly lowered, } 15 \mathrm{~mL} / \mathrm{g}(2) \text {. }\end{array}$ \\
\hline$\overline{\mathrm{Pb}}$ & 8000 & 10,000 & $\begin{array}{l}8000 \text { to } \\
80000\end{array}$ & $\mathrm{pH} 6$ and no competing ions: 13,000 to $79,000 \mathrm{~mL} / \mathrm{g} \mathrm{(14)}$ \\
\hline $\mathrm{Pu}$ & 50 & 150 & 50 to 2000 & $\mathrm{Pu}(\mathrm{V}, \mathrm{VI}): \mathrm{pH} 4$ to $12: 80$ to $>1980 \mathrm{~mL} / \mathrm{g}(15)$ \\
\hline $\mathrm{Ra}, \mathrm{Sr}$ & 5 & 14 & 5 to 200 & $\begin{array}{l}\text { Sr } \mathrm{K}_{\mathrm{d}} \text { values: } \\
\mathrm{Na} \text { system, } 173 \mathrm{~mL} / \mathrm{g}, 49 \text { to } 50 \mathrm{~mL} / \mathrm{g}(11) \\
\text { Ca system, } 8 \text { to } 13 \mathrm{~mL} / \mathrm{g}, 5 \text { to } 19 \mathrm{~mL} / \mathrm{g}(11) \\
5 \text { to } 120 \mathrm{~mL} / \mathrm{g}(15) \\
19.1 \text { to } 21.5 \mathrm{~mL} / \mathrm{g}(12) \\
\text { Na system, pH } 7 \text { to } 11,14.9 \text { to } 25.1 \mathrm{~mL} / \mathrm{g}(16) \\
\text { Most recent data using ILAW borehole sediment [299-E } 17-21] \text { yielded } 14.3 \pm 1.6 \text {. See (18). }\end{array}$ \\
\hline$\overline{\mathrm{Ru}}$ & 10 & 20 & 10 to 1,000 & Estimated (17 as cited in 11$)$ \\
\hline$\overline{\mathrm{Se}}$ & 3 & 7 & 3 to 15 & $\begin{array}{l}\text { Hanford groundwater/sediment system: }-3.44 \text { to } 0.78 \mathrm{~mL} / \mathrm{g}(12) \text {. Most recent data using ILAW } \\
\text { borehole sediment }[299-\mathrm{E} 17-21] \text { yielded } \mathrm{K}_{\mathrm{d}} \text { values ranging from } 3.75 \text { to } 10.85 \mathrm{~mL} / \mathrm{g} \text { and had an average } \\
\text { of } 6.7 \pm 1.9 \mathrm{~mL} / \mathrm{g}(18) .\end{array}$ \\
\hline $\mathrm{Th}, \mathrm{Zr}$ & 40 & 1000 & 40 to 2500 & $\begin{array}{l}\text { Estimated. } \\
\mathrm{Zr}: \mathrm{pH} 6 \text { to } 12: 90 \text { to }>2000 \mathrm{~mL} / \mathrm{g}(15)\end{array}$ \\
\hline $\bar{U}$ & 0.5 & $\overline{0.6}$ & 0.1 to 80 & $\begin{array}{l}\text { A review of Hanford sediment } U-K_{d} \text { values showed range of } 0.1 \text { to } 79.3 \mathrm{~mL} / \mathrm{g} \text { for } 13 \text { observations; } \\
\text { median was } 0.6 \mathrm{~mL} / \mathrm{g}(1) \text {. Results from later studies support the range }(2) \text {. In all reported data, some } \mathrm{U} \\
\text { was adsorbed by Hanford sediments and }>90 \% \text { of the values were between } 0.6 \text { and } 4 \mathrm{~mL} / \mathrm{g} \text {. Most recent } \\
\text { work with the ILAW Borehole sediment [299-E17-21] yielded } \mathrm{K}_{\mathrm{d}} \text { of } 0.6 \pm 0.1 \text {. See (18). }\end{array}$ \\
\hline
\end{tabular}




\begin{tabular}{|c|}
\hline es in this table describe sorption of radionuclides to Hanford sediment-dominated seque \\
\hline
\end{tabular}


Appendix C

Discussion on Double Layer and Film Thickness 


\section{Appendix C}

\section{Discussion on Double Layer and Film Thickness}

The double layer thickness was estimated from the Debye-Huckel Parameter (K) (Hiemenz and Rajagopalan 1997):

$$
\mathrm{K}=\left[\left(\frac{1000 e^{2} N_{A}}{\varepsilon k_{B} T}\right) \sum_{i} z_{i}^{2} M_{i}\right]^{1 / 2}
$$

Where $\mathrm{K}^{-1}(\mathrm{~m})$ is sometimes used to estimate the double layer thickness, $e$ is the electric charge (or charge of an electron, units $=\mathrm{C}), N_{\mathrm{A}}$ is Avogadro's number, $\varepsilon$ is fluid permittivity $\left(\mathrm{C} \mathrm{V}^{-1} \mathrm{~m}^{-1}\right), \mathrm{k}_{\mathrm{B}}$ is Boltzmann's constant $\left(\mathrm{J} \mathrm{K}^{-1}\right), z$ is the valence of the electrolyte, and $M$ is the electrolyte concentration $(\mathrm{M})$.

Assuming $\mathrm{Ca}^{2+}$ and $\mathrm{SO}_{4}{ }^{2-}$ are the dominant ions at an ionic strength of $10 \mathrm{mM}$, the double layer thickness based on Equation $\mathrm{A}$ is $1.5 \mathrm{E}-9 \mathrm{~m}$.

The film thickness was calculated with the following equation taken from Hillel (1980):

$$
\lambda=\frac{\theta}{\rho_{b} A_{s s}}
$$

Where $\lambda$ is the film thickness (cm), $\theta$ is the volumetric water content, $A_{s s}$ is the specific surface area $\left(\mathrm{cm}^{2} / \mathrm{g}\right.$ ) and $\rho_{\mathrm{b}}$ is the bulk density $\left(\mathrm{g} / \mathrm{cm}^{3}\right)$. Using $\theta=0.6, \rho_{\mathrm{b}}=1.25 \mathrm{~g} / \mathrm{cm}^{3}$, and $A_{s s}$ of $2000 \mathrm{~cm}^{2} / \mathrm{g}$ in Equation $B$, the film thickness $(\lambda)=2.4 \mu \mathrm{m}$.

Hillel, D. 1980. Fundamentals of Soil Physics. Academic Press. New York.

Hiemenz, P. C., and R. Rajagopalan. 1997. Principles of Colloid and Surface Chemistry, Third Edition. Marcel Dekker, Inc. New York. 


\section{Appendix D}

\section{Information Requested for Near-Field Geochemical Transport Modeling}




\section{Appendix D}

\section{Information Requested for Near-Field Geochemical Transport Modeling}

Reactive transport modeling of the waste form leaching and near field is being performed using the computer code STORM that is described in the Waste Form Leaching Data Package (McGrail et al. 1999).

The STORM code requires that the user provide the chemical formulas for the reactions needed to form the solid minerals that constitute the sediments and engineered barriers surrounding the glass waste forms. The Geochemical Data Package provides guidance in this appendix. "The mineralogy of the Hanford sand sediments that might be used for backfill and the native Hanford formation sands and gravels have not been characterized at the ILAW site. However some quantitative mineralogy of Hanford formation sediments taken from outcrops and from the sides of other solid waste disposal facilities in the $200 \mathrm{E}$ and $200 \mathrm{~W}$ areas have been reported. The data in Serne et al. (1993) pages 5-28. list detailed mineralogical, geochemical, hydrologic and physical characterization information for four sediments. This information can be used as input to STORM.

In FY00 about ten of the 21 samples from the ILAW borehole [299-E17-21] drilled in FY98 will be characterized for quantitative mineralogy and perhaps amorphous hydrous oxide content using the same techniques discussed in Serne et al. (1993). The 21 samples were used to obtain site specific $\mathrm{K}_{\mathrm{d}}$ values, cation exchange capacities, particle sizes and hydrologic parameters in FY98-9.9. These data have been documented in topical reports [Kaplan et al. 1998 and Reidel et al. 1998] and companion 2001 Data Packages [Khaleel 1999 and Reidel and Horton 1999].

Mineralogy data needed for the STORM code reactive transport calculations for cement and concrete and are available in the following topical reports [Criscenti and Serne 1990, Criscenti et al. 1996, and Krupka and Serne 1996] and references cited therein. Hydrologic and physical properties of cement and concrete are discussed in the Near Field Hydrology 2001 Data Package [Meyer and Serne 1999] and references cited therein.

For the 2001 ILAW PA all chemical dissolution/precipitation reactions for the backfill sediments, natural sediments, cements and concrete are assumed to reach equilibrium in each time step during the transport modeling. There is limited kinetic data available for the dissolution/precipitation reactions for these minerals/materials but the geochemists could not tabulate the information in time for the 2001 data packages. However kinetic data will be tabulated and made available to the STORM transport modelers in time for the 2003 PA activity. The amount of effort expended in tabulating kinetic information will be determined based on the importance of kinetics deciphered from critically analyzing the results of the near field transport modeling in the $2001 \mathrm{PA}$. 


\section{References}

Criscenti, L. J. and R. J. Serne. 1990. "Thermodynamic Modeling of Cement/Groundwater Interactions as a Tool for Long-Term Performance Assessment," in Scientific Basis for Nuclear Waste Management XIII, editors V. M. Oversby and P. W. Brown, Materials Research Society. Pittsburgh, Pennsylvania. Vol. 176: 81-90.

Criscenti, L. J., R. J. Serne, K. M. Krupka, and M. I. Wood. 1996. Predictive Calculations to Assess the Long-Term Effect of.Cementitious Materials on the pH and Solubility of Uranium(VI) in a Shallow Land Disposal Environment. PNNL-11182, Pacific Northwest Laboratory, Richland, Washington, D.C.

Kaplan, D. I., K. E. Parker, and I. V. Kutnyakov. 1998. Radionuclide Distribution Coefficients for Sediments Collected from Borehole 299-E17-21: Final Report for Subtask Ia. PNNL-11996, Pacific Northwest National Laboratory, Richland, Washington.

Khaleel, R. 1999. Far-Field Hydrology Data Package for Immobilized Low-Activity Tank Waste Performance Assessment. HNF-4769, Rev. 1, Fluor Daniel Northwest, Inc., Richland, Washington.

Krupka, K. M. and R. J. Seme. 1996. Performance Assessment of Low-Level Radioactive Waste Disposal Facilities: Effects on Radionuclide Concentrations by Cement/Ground-Water Interactions. NUREG/CR-6377, U.S. Nuclear Regulatory Commission, Washington, D.C.

McGrail, B. P., D. H. Bacon, J. P. Icenhower, W. L. Ebert, P. F. Martin, H. T. Schaef, and E. A. Rodriguez. 1999. Waste Form Release Data Package for the 2001 Immobilized Low-Activity Waste Performance Assessment. PNNL-13043, Pacific Northwest National Laboratory, Richland, Washington.

Meyer, P. D. and R. J. Serne. 1999. Near-Field Hydrology Data Package for the Immobilized LowActivity Waste 2001 Performance Assessment. PNNL-13035, Pacific Northwest National Laboratory, Richland, Washington.

Reidel, S. P. and D. G. Horton. 1999. Geologic Data Package for 2001 Immobilized Low-Activity Waste Performance Assessment. PNNL-12257, Rev. 1, Pacific Northwest National Laboratory, Richland, Washington.

Reidel, S. P., K. D. Reynolds, and D. G. Horton. 1998. Immobilized Low-Activity Waste Site Borehole 299-E17-21. PNNL-11957, Pacific Northwest National Laboratory, Richland, Washington.

Serne, R. J., J. L. Conca, V. L. LeGore, K. J. Cantrell, C. W. Lindenmeier, J. A. Campbell, J. E. Amonette, and M. I. Wood. 1993. Solid-Waste Leach Characteristics and Contaminant-Sediment Interactions. Volume 1: Batch Leach and Adsorption Tests and Sediment Characterization. PNL-8889, Vol 1. Pacific Northwest Laboratory, Richland, Washington. 


\section{Distribution}

No. of

Copies

\section{OFFSITE}

H. Babad

2540 Cordoba Court

Richland, WA 99352-1609

P. V. Brady

Geochemistry Department

Sandia National Laboratories

P.O. Box 5800

Albuquerque, NM 87185-0750

3 D. I. Kaplan

Westinghouse Savannah River Company

Building 774-43A, Room 215

Aiken, SC 29808

S. Serkiz

Westinghouse Savannah River Company

Building 773-A, Room B-121

Aiken, SC 29808

\section{FOREIGN}

T. T. Vandergraaf

Atomic Energy of Canada, Limited

Whiteshell Nuclear Research Establishment

Pinawa, Manitoba ROE 1LO

Canada

\section{ONSITE}

\section{Bechtel Hanford, Inc.}

B. H. Ford

$\mathrm{H} 0-21$

G. A. Jewell (2)

H0-21
No. of

Copies

4 Fluor Daniel Northwest, Inc.
E. J. Freeman
B4-43
R. Khaleel
B4-43
F. M. Mann
$\mathrm{H} 0-22$
R. J. Puigh
B4-43

4 Lockheed Martin Hanford Corporation

D. A. Burbank

S4-45

K. C. Burgard

S4-45

T. E. Jones (MACTEC)

$\mathrm{H} 0-22$

A. J. Knepp

H0-22

R. W. Root

R2-53

Waste Management

M. I. Wood

H6-06

2 DOE Office of River Protection

C. A. Babel

H6-60

P. E. LaMont

H6-60

26 Pacific Northwest National Laboratory

D. H. Bacon

K9-33

R. W. Bryce

K6-75

M. J. Fayer

K9-33

A. P. Gamerdinger

K6-81

G. W. Gee

K9-33

D. G. Horton

K6-81

C. T. Kincaid

K9-33

C. W. Lindenmeier

K6-81

B. P. McGrail

K9-81

S. V. Mattigod

P. D. Meyer
$\mathrm{K} 6-81$

BPO 
PNNL-13037, REV. 1

No. of

Copies

K. E. Parker.

K. P. Saripalli

R. J. Serne (5)
No. of

Copies

K6-81

K6-81

K6-81
S. P. Reidel

Information Release Office (7)
K6-81

K1-06 